A FEA e a USP respeitam os direitos autorais deste trabalho. Nós acreditamos que a melhor proteção contra o uso ilegítimo deste texto é a publicação online. Além de preservar o conteúdo motiva-nos oferecer à sociedade o conhecimento produzido no âmbito da universidade pública e dar publicidade ao esforço do pesquisador. Entretanto, caso nào seja do intercsse do autor manter o documento online, pedimos compreensão em relação à iniciativa e o contato pelo e-mail bibfea@usp.br para que possamos tomar as providências cabiveis (remoção da tese ou dissertação da BDTD). 


\begin{abstract}
UNIVERSIDADE DE SĀO PAULO
FACULDADE DE ECONOMIA E ADMINISTRAÇĀO

DEPARTAMENTO DE CONTABILIDADE E ATUÁRIA
\end{abstract}

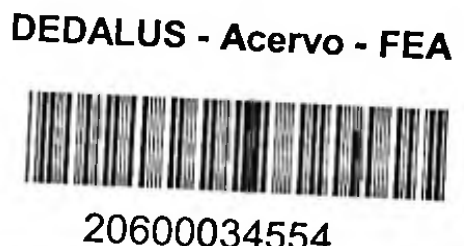

CONTRIBUIÇĀO A MENSURACĀO E CONTABILIZAÇĀO DO GOODWILL NĀO ADQUIRIDO

- TESE DE DOUTORAMENTO -

$6 ! 757$

MASSANORI MONOBE

ORIENTADOR: Prof. Dr. Eliseu Mortins 
aos meus pais Massaro e Sumie que, não tendo oportunidade de acesso a uma formaçäo escolar mais aprimorada, nāo medi ram esforços no sentido de consegui-la para os seus filhos, provendo todas as condições materiais e o necessārio amparo espiritual nas horas mais deficeis;

à minha esposa Regina Cëlia, pela compreensäo que sempre manifestou, pelos incentivos nos momentos cruciais e pelo amor com que me motivou para o empreendimento desta ärdua tarefa;

a todos os meus familiares que sempre me propiciaram um alegre e sadio convivio, bem como os estimulos indispensia veis a superação dos obstāculos surgidos. 


\section{A GRADECIMENTOS}

Gostaria de manifestar o meu mais sincero agradecimento ao Prof.Dr. Eliseu Martins que, gentil e amigavelmente, dedicou horas de seu precioso e escasso tempo à orientação do presente trabalho, não poupando momentos do seu merecido descanso.

Da mesma forma, nãj poderia esquecer o Prof. Dr. Sërgio de Iudícibus, cujas säbias ponderações e cujo incentivo muito contribuiram para a consecução desta obra.

Um especial agradecimento aos Profs. Drs. Antonio Peres Rodrigues Fi lho, Antonio Pereira do Amaral, Alecseo Kravec e Alkindar de Toledo Ramos pelo imprescindivel incentivo e apoio à busca desse caminho que tão brilhantemente trilharam.

A Profa. Cecilia A.K.Chinen, Masayuki Nakagawa, Läzaro Pläcido Lisboa, enfim, a todos os professores e companheiros do Departamento, que sempre me incentivaram ao empreendimento dessa tarefa, os meus sinceros agradecimentos.

Finalmente, não poderia deixar de agradecer aqueles que, jā na sua fase final de elaboração, permitiram o "fechamento" deste trabalho: Luis S. Monobe e Gerson Ota, pela feitura dos preciosos grä́ficos; Maridi pelos imprescindiveis serviços datilogräficos; e, Yoshito Fujii, pela cessão gentil de sua copiadora xerox. 


\section{INTRODUCÃO}

A Contabilidade, modernamente definida como um sistema de informações para á tomada de decisões, atua num universo onde as mudanças são cada vez mais rāpidas, impondo a necessidade de uma adequacão a essa realidade, sob o risco de tornar-se "descartāvel" como fonte informativa.

Com 0 advento e desenvolvimento, no contexto da economia, da Administracão Científica, a preocupacão cres cente com a utilizacão e combinacão mais eficazes dos recur sos escassos, bem como a necessidade de conhecer as perspec tivas futuras da entidade, tornou-se imprescindivel, para melhor cumprimento dos objetivos administrativos, a função Planejamento-Execucão-Controle, cujo bom desempenho depende das informacões geradas pela Contabilidade.

Por outro lado, com a sofisticacão da economia e o acirramento da concorréncia, as decisões concernentes ao futuro passaram a ser definitivamente mais importantes, com o planejamento estratēgico tomando tempo cada vez maior dos executivos de alto escalão. O fornecimento de dados relevan tes acerca do futuro, não sō para os usuārios internos, mas tambēm para os externos, constitui-se no momento num dos grandes desafios da Contabilidade, cujos procedimentos conven cionais não mais satisfazem as necessidades de informacões 
dos tomadores de decisões, motivando severas crïticas.

0 futuro sempre se cercará do risco da incerteza, mas ignorá-lo por essa razão, apegando-se no conservadoris mo e na objetividade dos dados verificāveis, trará, como consequência, igualmente, a não confiabilidade dos dados contābeis por totalmente irrelevantes para os usuários.

Nesse necessārio esforço de adequação da Contabili dade para o melhor desempenho de sua real função, qual seja a de fornecer informações relevantes para a tomada de decisões, ē imprescindīvel uma maior participação de estudiosos e profissionais da ārea contābil - o resultado bem sucedido serā uma maior aproximacão de suas afins a Economia e a Administração.

Buscando esse objetivo de maior aproximação com a Economia e Administraça, estudos pioneiros foram realizados por professores da Faculdade de Economia e Adminis tração da USP, entre os quais podem ser citados: "Contri buicão a Teoria dos Ajustamentos Contäbeis" e "Aspectos da Avaliação de Estoques a Preços Correntes", ambos de autoria do Prof. Dr. Sergio de Iudicibus, "0 Problema da Depre ciacão e as Necessidades Administrativas das Empresas", do Prof. Dr. Alkindar de Toledo Ramos, e, "Contribuicão à Ava liacão do Ativo Intangivel", do Prof. Dr. Eliseu Martins".

Dentro do mesmo espirito, o presente trabalho objetiva enfatizar a relevāncia e a comparabilidade das demonstrações contābeis, apresentando uma contribuição à men suração e contabilização do goodwill não adquirido, um pro 
cedimento muito reclamado por aqueles que apontam a contabilizacão apenas do goodwill adquirido como uma das gran des incongruēncias da Contabilidade, alēm de causa de inūmeras distorcões. A escassez, para não dizer inexistência, de obras de autores europeus e japoneses, pertinentes ao assunto, em funcão do privilegiamento da literatura em inglês, impossibilitou um estudo comparativo com os desenvol vimentos da chamada escola americana.

"Contribuicão a Mensuração e Contabilização do Goodwill não Adquirido" divide-se em cinco capitulos, a sa ber:

CAPITULO I . FUnÇ̃̃o DA CONTABILIDADE E OBJETIVOS DAS DEMONSTRACÕES CONTÁBEIS

Nesse capitulo è abordada a Contabilidade no contexto do mundo das decisões, considerando a sua funcão de supridora de informacões o que, como e para quem transmi tir as informações contábeis, bem como as controvéríias re lativas a publicaça de dados prospectivos relevantes para os usuārios.

CAPITULO II - GOODWILL: CONCEITOS E NATUREZA

Aqui foram apresentados os diversos conceitos de goodwill, a evolucão conceitual desde o seu aparecimento e a natureza do goodwill, que tanta discussão tem suscitado. 
CAPfTULO II . MENSURAÇ̃o E CONTABILIZACÁO DO GOODWILL

Neste capitulo são analisados, de forma bastante abrangente, os métodos de mensuracão e contabilizacão do goodwill, os argumentos utilizados para sua adocão, bem co mo as dificuldades relacionadas com a mensuraça do goodwill.

\section{CAPITULO IV , PROCEDIMENTOS PROPOSTOS}

Constitui-se na contribuicão propriamente dita do autor deste trabalho, onde, na impossibilidade de avaliar - valor económico individual dos ativos, para apurar o valor do goodwill sinergistico, é proposta a ativacão de gas tos com Pesquisa/Desenvolvimento e Propaganda/Publicidade e a avaliação do valor corrente dos ativos, como forma de ob tenção de um goodwill mais relevante, principalmente em função de sua reavaliacão anual. O enriquecimento das informacões contābeis com a apresentação, mesmo que paralela mente, do goodwill global da empresa e de dados prospectivos a ela relacionados, fornecerā um amparo mais seguro às decisões dos usuārios.

Entretanto, a solucão definitiva para a grande maioria dos problemas está na ampliacão dos fatores de lucro sujeitos à contabilização, que, por sua vez, depende da reformulacão da teoria contābil, especialmente na parte concernente aos princíplàls e convencões contābeis geralmen te aceitos. 


\section{ABSTRACT}

This work intends to present a form of measuring and accounting non-purchased goodwill, as a way to avoid distortions in financial analysis by accounting information users.

In this sense,it is divided into four chapters as presented below:

Chapter I Function of Accounting and objectives of Financial Statements

This chapter fotcusses the Accounting in the context of world of decisions, considering Accounting as information supplier - What, How and Whom inform. The controversy about publication of predictive data useful for decision makers is also analysed.

Chapter II Goodwill: Concepts and Nature Here, it is presented several concepts of goodwill, and the historical of the nature of goodwill.

Chapter III. Measurement and Accounting of Goodwill

This chapter analyses all used methods of measuring and accounting of acquired goodwill. It also foccusses difficulties related to goodwill measurement.

Chapter IV. Proposed Treatments to Goodwill 
It is presented here the contribuition of the author, that consists of measuring and accounting goodwill, including purchased and non-purchased goodwill, by using a form of current value accounting.

The presentation of predictive data in financial statements will certainly be of high utility for accounting information users in their decision models. 
CAPÍTULO I

FUNCÃO DA CONTABILIDADE E OBJETIVO DAS DEMONSTRAÇ̃̃ES

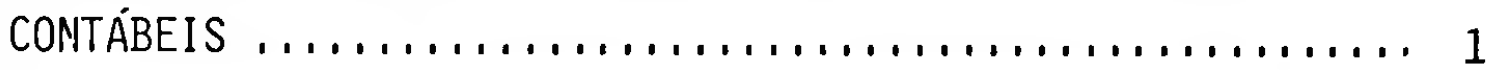

1.1. CONTABILIDADE COMO SISTEMA DE INFORMAÇ̃̃ES PARA

A TOMADA DE DECISÕES $\ldots \ldots \ldots \ldots \ldots \ldots \ldots \ldots \ldots \ldots, 2$

1.1.1. INFORMAÇÓES CONTÁBEIS E PROCESSO ADMINIS TRATIVO DO PLANEJAMENTO, EXECUÇAO E CONTROLE $\ldots \ldots \ldots \ldots \ldots \ldots \ldots \ldots \ldots \ldots \ldots \ldots \ldots \ldots, 2$

1.1.2. O QUE, COMO E PARA QUEM INFORMAR $\ldots \ldots \ldots \ldots \ldots 4$

1.1.3. OBJETIVOS DOS RELATORIOS FINANCEIROS ........ 5

1.1.4. ESTAGIO ATUAL DAS. INFORMACOES CONTABEIS PUBLICADAS $\ldots \ldots \ldots \ldots \ldots \ldots \ldots \ldots \ldots \ldots \ldots, 7$

1.1.5. CONTABILIDADE COMO INSTRUMENTO DE MENSURACÃO OU AVALIACÃO $\ldots \ldots \ldots \ldots \ldots \ldots \ldots \ldots \ldots$

1.2. CONTROVÉRSIAS SOBRE A PUBLICACÃO DE DADOS PROS-

PECTIVOS $\ldots \ldots \ldots \ldots \ldots \ldots \ldots \ldots \ldots \ldots \ldots \ldots \ldots, 22$

$1,2,1$. NATUREZA DAS PREVISOEES $\ldots \ldots \ldots \ldots \ldots \ldots \ldots \ldots, 22$

1.2.2. POR QUE PUBLICAR DADOS PROSPECTIVOS? ....... 23

1.2.3. RESISTENCIAS A PUBLICACÃO DE DADOS PROS-

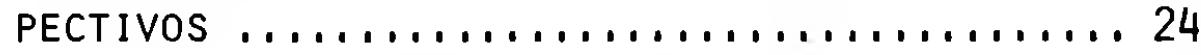

1.3. Dilema DA CONTABILIDADE: PROgRESSO OU ESTAGNACÃO? $\ldots 26$ 1.3.1. DINAMICIDADE DO CAMPO DE ATUAC,ÃO DA CON

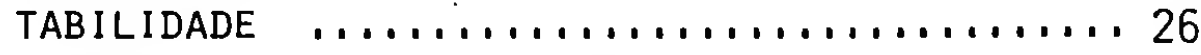

1.3.2. EXIGENCIA DE ADEQUACÃO DA CONTABILIDADE COMO SISTEMA INFORMATIVO $\ldots \ldots \ldots \ldots \ldots \ldots \ldots 29$

1.3.3. ORGAOS QUE INTERVEM NO CAMPO CONTABIL ...... 33

1.3.4. CONTABILIDADE PREDITIVA: UM OBJETIVO ALCANCÁVEL?.

CAPITULO II

GOODWILL: CONCEITOS E NATUREZA $\ldots \ldots \ldots \ldots \ldots \ldots \ldots \ldots, 41$ 2.1. DEFinicão DE ATIVO INTANG IVEL $\ldots \ldots \ldots \ldots \ldots \ldots \ldots \ldots, 42$ 2.1 .1 . O QUe E uM ativo intang fVel? $\ldots \ldots \ldots \ldots \ldots, 42$ 
2.1.2. GOODWILL UM INTANGIVEL MUITO EXPECIAL ...... 44 2.2. CONCEITOS E NATUREZA DO GOODHILL .............. 45 2.2.1. RAZOES DA PREFERENCIA PELO TERMO

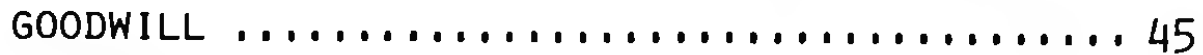

2.2.2. REFERENCIAS HISTORICAS $\ldots \ldots \ldots \ldots \ldots \ldots \ldots \ldots, 46$

2.2.3. EVOLUÇ.ÃO CONCEITUAL E NATUREZA DO GOODWILL ... 50

2.2.4. GOODWILL SEMPRE UM CONCEITO RESIDUAL? ....... 58

$2,2,5$, GOODWILL NEGATIVO OU BADWILL $\ldots \ldots \ldots \ldots \ldots, 60$

2.2.6. CONCEITO IDEAL: GOODWILL SINÉRISTICO $\ldots \ldots, 60$ 2.3. VALOR DO GOODWILL E SUA RELEVÂNCIA PARA USUÁRIOS $\ldots 62$ CAPÍTULO III

MENSURACÃO E CONTABILIZACÃO DO GOODHILL ............. 64

3.1. VALOR DO GOODWILL: UM DEPENDENTE $\ldots \ldots \ldots \ldots \ldots \ldots \ldots 65$

3.1.1. FATORES ENVOLVIDOS NA AVALIACAO DO GOODWILL .. 65

3.1.2. FORMAS DE AVALIACÃO DO GOODWILL ..........6 66

3.1.3. DIFICULDADES RELATIVAS A MENSURACÃO ........ 84

3.1.4, GOODWILL SINERGISTICO: UM RESULTADO DA MENSURAÇ̃O IDEAL $\ldots \ldots \ldots \ldots \ldots \ldots \ldots \ldots \ldots \ldots$

3.2. TRATAMENTOS CONTÁBEIS ADOTADOS $\ldots \ldots \ldots \ldots \ldots \ldots \ldots \ldots . \ldots \ldots$

3.2.1. GOODWILL UM INCONVENIENTE INEVITÁVEL ........103

3.2.2. GOODWILL NAO ADQUIRIDO X GOODWILL ADQUIRIDO ..104

3.2.3. FORMAS DE TRANSACÃO E GOODWILL ............115

3.2.4. PROCEDIMENTOS ADOTADOS QUANTO AO GOODWILL

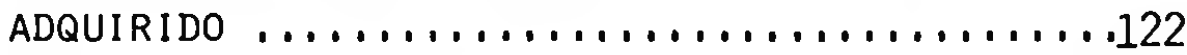

CAPITULO IV

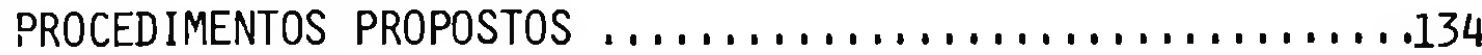

4.1. MENSURACÃO DO GOODHILL GLOBAL E REAVALIACÕES CONS-

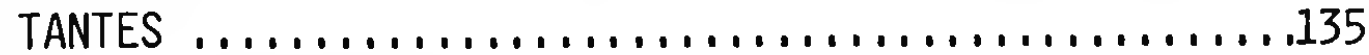

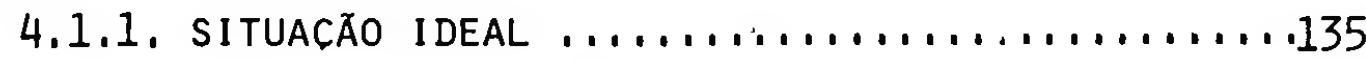

4.1.2. TRATAMENTO CONTÁBIL IDEAL $\ldots \ldots \ldots \ldots \ldots \ldots \ldots 141$

4.2. PROCEDIMENTOS IDEAIS $X$ PROCEDIMENTOS PROPOSTOS $\ldots \ldots .143$ 4.2.1. IMPRATICABILIDADE DOS PROCEDIMENTOS IDEAIS ...143 4.2.2. MÉTODOS DISPONIVEIS PARA MENSURACÃO DO GOODWILL ..........................146 


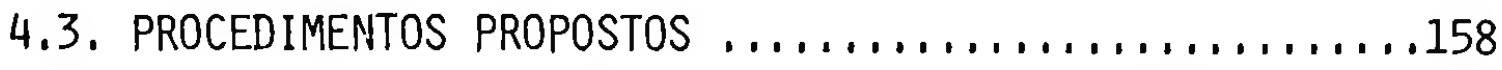
4.3.1. APURAÇÃO DO GOODWILL GLOBAL UTILIZANDO MÉTOdO DE VALORES CORRENTES .............158 4.3.2. REAVALIAÇ̃ES ANUAis DO GOODWILL GLOBAL .......163 4.3.3. CONTABILIZACÃO DO GOODWILL GLOBAL ...........164

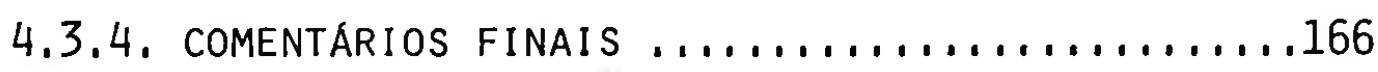

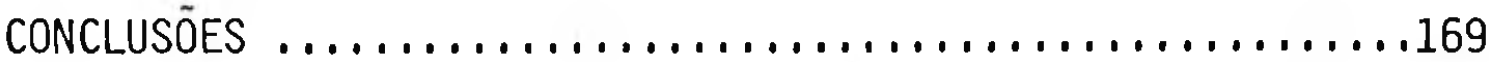

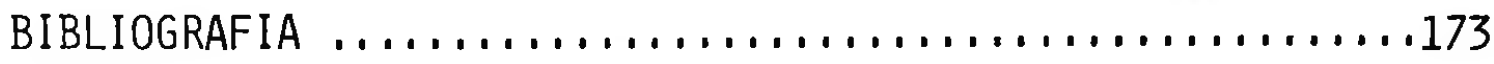




\section{CAPITULO I}

FUNCĀOO DA CONTABILIDADE E OBJETIVOS DAS DE:ONSTRACÖES CONTABBEIS 


\section{CAPITULO I}

FUNCĊ̃O DA CONTABILIDADE E OBJETIVOS DAS DEMONSTRACÕES COMTÁBEIS

1.1. CONTABILIDADE COMO SISTEMA DE INFORMAC̄ÕES PARA TOMADA DE DECISÕES

1.1.1. INFORMAÇÕES CONTABEIS E PROCESSO ADMINISTRATIVO DO PLANEJAMENTO EXECUCÃO E CONTROLE

A evolucão do sistema capitalista trouxe consigo - acirramento da concorréncia como consequência natural, bem como a necessāria profissionalizacão da Administraça, na medida em que o bom senso deixou de ser um requisito su ficiente para o sucesso dos negōcios.

0 uso de tēcnicas cada vez mais sofisticadas, inte grando ciēncias correlatas como a Estatistica, Sociologia, Psicologia, Economia e Contabilidade, entre outras, promoveu um rápido desenvolvimento do instrumental disponível ao administrador no desempenho de suas funcões, sem o que sua tarefa seria dificultada pelo contexto de incertezas em que os negócios se desenrolam e onde as variāveis sociais tem um papel preponderante.

Atuar num contexto dessa natureza, sem um eficiente sistema de informacões, impossibilitaria a tomada de qualquer decisão racional e confiāvel, aumentando considevelmente o risco dos negócios. A Contabilidade registrando, classificando, analisando e resumindo os dados relativos as transacões realizadas pela empresa propicia informacões 
indispensāveis para o funcionamento do processo administra tivo de planejamento, execução e controle, o trinōmio fundamental da Administração Moderna. Numa definição mais moderna, poder-se-ia dizer que a contabilidade $\bar{e}$ um sistema de processamento de informações destinado a captar e medir a essēncia económica dos eventos que afetam a entidade e relatar seus efeitos econōmicos sobre a mesma entidade para os tomadores de decisões.

Jā O Americam Institute of Certified public Accountants (AICPA), atravēs do "Statement of APB no 4", Conceitos Básicos e Princípios Contábeis Subjacentes aos "Statements" Financeiros de Empresas, assim a definiu:

\begin{abstract}
"Contabilidade ē uma atividade serviço. Sua função é prover informação quantitativa, primordial mente de natureza financeira, acerca das entidades econōmicas, julgada ūtil na tomada de decisões econōmicas - em fazer escolhas racionais entre cursos alternativos de açăo..."
\end{abstract}

Assim, a Contabilidade fornecendo as informações contābeis que, juntamente com as informações não contābeis, constituem o sistema de informações à disposição da Administração para fundamentar as suas decisöes, desempenha um papel decisivo na gestão das entidades.

Igualmente, são indispensāveis as informações gera das pela contabilidade aos usuārios externos à empresa, pois é a ünica forma confiāvel pela qual podem avaliar o desempenho de uma entidade e o de seus administradores,com vistas a tomada de decisões a ela pertinentes. 


\section{].1.2. O NUE, COMO E PARA QUEM INFORMAR}

Tratando-se da forma pela qual os usuärios, especialmente os externos, podem conhecer a empresa, são de crucial importāncia as questões relativas a "o que, como e para quem" destinar as informações contábeis, jā que definem a estrutura necessäria ao provimento dessas informações. São questões intimamente relacionadas entre si pois "o que e como" dependem do tipo de necessidades requeridas pelos usuārios para as suas decisões, bem como de sua capa cidade de interpretar corretamente as informações fornecidas nas demonstrações.

Parece razoāvel, dessa forma, iniciar a definição da estrutura informativa a partir dos usuārios, a prōpria razäo de ser das informações contábeis. No tocante a êsse aspecto, são basicamente duas as alternativas:

a. prover informações para usuários indistintos com mūltiplos objetivos de decisäo, i.ê, elaborar relatórios financeiros para fins gerais;

b. prover informações para grupos de usuārios específicos com objetivos de decisão conhecidos, contendo as informações relevantes para os seus modelos particulares de decisão.

As questões relativas a "o que e como" ficam pelo menos parcialmente delimitadas com a definicão dos usuá rios externos a que se destinam as informacões, pois 0 seu conhecimento e o de suas necessidades determinarão não só o conteudo dos relatōrios contābeis, bem como a ling̣uagem mais adequada nara a sua comunicacão. 


\subsubsection{OBJETIVOS DOS RELATÓRIOS FINANCEIROS}

A função dos relatörios financeiros tem sido enten dida como a de fornecer informaça ūtil para a tomada de decisões económicas - para possibilitar a escolha racional entre os usos alternativos de recursos escassos. Entretanto, não obstante a relativa antiguidade desse conceito, 0 conteudo dos relatōrios financeiros tem pecado pela sua insuficiência no cumprimento da finalidade proposta.

Em resposta às crīticas aos Relatōrios financeiros das Sociedades Anonimas, O AICPA formou o Grupo de Estudos sobre os Objetivos dos Relatörios Financeiros (o "Trueblood Committee") para trabalhar sobre as seguintes questões:

1. Quem necessita dos relatōrios financeiros?

2. Que informação necessitam?

3. Quanto da informação necessāria pode ser fornecida pelos contadores?

4. Que estrutura é requerida para o provimento da informação necessāria?

Em seu relatōrio, apresentado em 1973, 0 "Trueblood Committee" concluiu sobre os Objetivos dos Relatörios Financeiros:

- ... fornecer aos usuārios informações necessārias para prever, comparar e avaliar a capacidade de lucro da empresa ...

- fornecer informacões fatuais e interpretativas acerca das 
transacões e outros eventos, as quais são üteis para pre visão, comparação e avaliação da jā citada capacidade de lucro da empresa

- relatar os valores correntes, quando diferirem significa tivamente dos custos histöricos..."

0 Comitê enfatizou claramente a necessidade de as informacões contidas nos Relatórios Financeiros serem ūteis ao processo preditivo, embora não tenha recomendado explicitamente a publicacão de previsões pela própria empresa.

Por outro lado, ressaltou as qualidades desejāveis nas informacões fornecidas: relevāncia, verificabilidade, neutralidade, oportunidade e comparabilidade, entre ou tras.

Os dados preditivos tornam-se mais importantes na medida em que hā uma preocupacão crescente, tanto dos usuá rios internos como externos, com as expectativas futuras relativamente as empresas, desfrutando de maior vantagem aqueles que antecipam decisões por melhor "enxergarem"o fú turo. Assim o fazem os investidores e investidores em potencial para avaliar os investimentos na empresa e tomar suas decisões. Da mesma forma, quanto mais alto o escalão administrativo, maior vai sendo a parcela de seu tempo gas to no exercício da "futurologia empresarial" - a concorrēn cia mais importante não mais concerne a gestão do presente mas em delinear as decisões estatēgicas relativas as con junturas econōmicas futuras cada vez mais distantes. 
Nesse aspecto, são os usuärios externos os grandes prejudicados pois tem que se basear primordialmente nos da dos publicados pela Contabilidade Financeira, sensivelmente mais pobres, enquanto os usuärios internos, a Adminis tracão especialmente, tem a sua disposicão todo um fluxo de informacões privilegiadas propiciado por um campo especiffico da Contabilidade, a Contabilidade Gerencial, a qual não estando sujeita à restricão dos principios e conven cões contábeis, tem experimentado um grande; desenvolvimento.

A respeito do aspectó formal dos relatōrios contā.beis, existe uma corrente na Teoria Contábil, os defenso res do "Events Theory Accounting", que julgam muito mais relevantes para a tomada de decisões particulares o enfoque dos eventos que afetam a empresa, criticando especialmente a publicacão de dados condensados, que poderiam esconder detalhes importantes.

\subsubsection{ESTAGIO ATUAL DAS INFORMAÇOES CONTÁBEIS PUBLICADAS}

As informações contäbeis decorrentes dos procedi mentos de acordo com os principios e convencões contābeis geralmente aceitos privilegiam apenas o passado, permitindo a avaliação nem sempre eficiente das decisões passadas. Para os usuārios externos, essas informacões contābeis representam a empresa como a fotografia de um "iceberg" - a parte invisivel pode ser muito mais significativa para as 
suas decisões que aquela que assoma à superfície das demonstracões.

A despeito das inūmeras resistēncias daqueles que defendem a imutabilidade da estrutura da teoria contábil, jā existe quase um consenso de que pelo menos alguns principios e convencões geralmente aceitos devem ser reformula dos, face ao contexto em que foram estabelecidos e a dinamicidade crescente dos negōcios e da ciência administrativa, que requerem uma postura condizente da Contabilidade, sob o risco de ser relegada a um segundo plano como fonte informativa.

A Contabilidade jā não pode repousar na segurança de sua objetividade pois, da mesma forma, suas informações deixarão de ser confiāveis por irrelevantes. Só assim, a Contabilidade Financeira proverā os usuārios externos de informacões mais relevantes, eliminando, pelo menos par cialmente, o "gap" informativo em relacão aos usuários internos.

1.1.5. CONTABILIDADE COMO INSTRUMENTO DEMENSURAC̄̃o OU AVALIAÇ̃̃O

\subsubsection{FUNÇ̃̃O DA CONTABILIDADE}

Na definição mais moderna de contabilização"captar e medir a esséncia econōmica dos eventos que afetam a enti dade ..." fica explícita essá suar.importante funcão.

Alguns autores julgam ser a mensuração da renda a 
funcão central da ciēncia contäbil, realcando a importān cia da Demonstração de Resultados como fonte informativa do desempenho da empresa. Mas no que consiste realmente a ren da, objeto da mensuraçäo contābil?

\subsubsection{CONCEITO ECONOMICO E CONTÁBIL DE RENDA}

a. RENDA ECONÓMICA - Trata-se da renda tal como definida pelos economistas. Para Keynes, considerado um dos maio res economistas de todos os tempos, renda correspondia a soma do consumo mais a poupanca, um conceito macroeco nōmico de difícil, se não impossível, adaptacão a mensu racão contābil. A renda ideal ou padrão de Fisher equivale a soma algébrica dos recebimentos liquidos esperados de uma propriedade especifica, que Canning adaptou, incluindo as mudanças de valor da propriedade até a sua realizacão. Os rendimentos líquidos da liquidacão de uma firma mais as retiradas efetuadas pelos proprieta rios durante o periodo e menos o capital investido pelos mesmos constituiria a renda total final (1). Jä se tornou clāssica, por outro lado, a definicão de renda de Hicks ${ }^{(2)}$, como o montante que um homem pode consumir durante um periodo e ainda permanecer tão rico no final do periodo quanto o era no inicio. Este conceito foi

(1) Apud Kenneth S. Most - "Accounting Theory" $-2^{\text {nd }}$ Edition Grid Publ. Inc. Columbus Ohio, 1979, p. $212 / 215$.

(2) Hicks,J.R. - "Value and Capital" - Oxford University Press, 1939 - pg. 172 . 
adaptado para o contexto empresarial por Alexander (3): o motante que a empresa poderia distribuir aos seus acionistas, sōcios ou titulares, durante um periodo, e manter no final de periodo a mesma riqueza (igual patrimonio líquido) do início do período. Riqueza para Alexander seria medida em termos de fluxos futuros de caixa descontados a uma taxa de juros subjetiva, fluxos e taxa conhecidos com certeza. A taxa de juros sub jetiva corresponderia a uma taxa de desconto em que pa ra a entidade haveria uma indiferença quanto ao dinhei ro futuro ou presente.

Embora o conceito ideal de renda, a necessidade de conhecimento com certeza do futuro è um fator limitante da sua aplicabilidade, o que foi reconhecido pelos seus prōprios defensores.

Kenneth S. Most ${ }^{(4)}$ apresenta um exemplo numérico do que denomina Modelo de Fisher-Hicks, considerando as seguintes condicões:

- aquisicão em $t_{0}$ de 10000 ações da Cia AB por $\$ 11479$;

- recebimento de dividendos: $\$ 1000$ em $t_{1}, \$ 2500$ em $t_{2}, \$ 3700$ em $t_{3}$

(3) Alexander, Sidney s. - "Income measurement in a Dynamic economy" in Baxter, W.T. \& Davidson Sidney (ed.). "Accounting Theory". Richard D. Irwin Inc. Homewood, Illinois, 1962, p. 139.

(4) Most, Kenneth S. - "Accounting Theory", $2^{\text {nd }}$ edition, Grid Publishing Inc. 1981, pg. 215/216. 
- venda das acões em $t_{4}$ por $\$ 7000$;

- taxa de descontos: $7 \%$ a.a

$\cdot Y_{e}=C+\left(k_{n}-k_{n-1}\right)$, sendo

ye a renda

c o fluxo líquido de caixa

$k$ o capital (fluxos futuros de caixa descontados)

Assim, ter-se-ia:

\begin{tabular}{|c|c|c|c|c|c|}
\hline períodos & C & $k_{n}$ & $k_{n-1}$ & $Y_{e}$ & $\begin{array}{l}\text { Depreciação } \\
\text { Implicita }\end{array}$ \\
\hline$t_{0}-t_{1}$ & 1000 & 11282 & 11479 & 803 & 197 \\
\hline$t_{1}-t_{2}$ & 2500 & 9572 & 11282 & 790 & 1710 \\
\hline$t_{2}-t_{3}$ & 3700 & 6542 & 9572 & 670 & 3030 \\
\hline$t_{3}-t_{4}$ & 7000 & 0 & 6542 & 458 & 6542 \\
\hline
\end{tabular}

Renda Total ................... 2721

Depreciação Total (Poupança) ............... 11479

Note-se que a renda final, como não poderia deixar de ser, é a mesma do conceito contābil (\$14 200 - \$11 479), di ferindo entretanto a sua distribuicão pelos períodos.

Assumindo agora a reaplicação da renda à taxa de $7 \%$ a.a., ter-se-ia um retorno permanente de $\$ 803$, que corresponde a renda económica sobre um capital constante: 


\begin{tabular}{|c|c|c|c|c|c|c|}
\hline \multirow{2}{*}{$\frac{\text { períodos }}{t_{0}-t_{1}}$} & \multirow{2}{*}{$\frac{Y_{e}}{803}$} & \multirow{2}{*}{$\begin{array}{l}\text { Juros s/ } \\
\text { Poupança } \\
0\end{array}$} & \multirow{2}{*}{$\begin{array}{c}\begin{array}{c}\text { Retorno } \\
\text { Total }\end{array} \\
803\end{array}$} & \multicolumn{3}{|c|}{$\begin{array}{l}\text { Cálculo } \\
\text { dos Juros }\end{array}$} \\
\hline & & & & \multicolumn{3}{|c|}{-} \\
\hline$t_{1}-t_{2}$ & 790 & 13 & 803 & $7 \%$ & $x$ & 197 \\
\hline$t_{2}-t_{3}$ & 670 & 133 & 803 & $7 \%$ & $x$ & 1907 \\
\hline$t_{3}-t_{4}$ & 458 & 345 & 803 & $7 \%$ & $x$ & 4937 \\
\hline$t_{4}-t_{5}$ & 803 & 0 & 803 & $7 \%$ & $x$ & 11479 \\
\hline
\end{tabular}

b. RENDA CONTÁBIL - os contadores, em geral, consideram impraticā vel a mensuração da renda de uma empresa atravēs de rea valiações anuais de todos os recursos da mesma. Renda de uma entidade, para os contadores, ma is preocupados com a praticidade do conceito, corresponde ao lucro (receitas - despesas + ganhos - perdas) da mesma, o qualē men surado de conformidade com os principios e convencões contäbeis geralmente aceitos.

Os componentes do Lucro Contābil teriam as seguintes definições:

b.1. RECEITA - "Entende-se por receita a entrada de elemen tos para o ativo, sob a forma de dinheiro ou direitos a receber, correspondentes, normalmente, à venda de mercadorias, de produtos ou à prestacão de servicos " (Contabilidade Introdutōria) ${ }^{(5)}$ ou

(5) Iudicibus, Sergio; Ramos, Alkindar de T.; Kanitz, Stephen C.; Martins, E1iseu; Weber, Fo Eduardo; Weber,Jr.Eduar do; Castilho, Edison e Benatti, Luiz - "Contabilidade" Introdutoria" - Atlas. 
"inflows or other enhancements of assets of an entity or settlements of its liabilities (or a combination of both) during a period from delivering or producing goods, rendering services, or other activities that constitute the entity's ongoing major or central operations" (FASB, 1980) ${ }^{(6)}$ ou ainda "... monetary expression of the aggregate of products or services transferred by an enterprise to its customers during a period of time" (Committee of Concepts and Standards for Accounting and Reporting, $A A A$, 1957 ).

b.2. DESPESA - "Entende-se por despesa o consumo de bens ou servicos que, direta ou indiretamente, deverá pro duzir uma receita. Diminuindo o ativo ou aumentando o passivo, uma despesa é realizada com a finalidade de se obter uma receita cujo valor seja superior a diminuição que provoca no patrimōnio liqquido" (Contabilidade Introdutoria) ou
"expenses are resources used during a period of time which are capable of expression in money, regardless whether they originate from

(6) FASB Statement of financial accounting concepts n? 3 "Elements of Financial Statements of Business Enterprises", 1980. 
current, past or future expenditures"

b.3. GANHOS E PERDAS - "Gains are increases in equity (net assets) from peripheral or incidental transaction of an entity and from all other events and circumstances affecting the entity during a period expected those that result from revenues or investments by owners" Accounting Principles Board (APB) Statement no 4.

"losses are decreases in equity (net assets)

from peripheral or incidental transactions or

other events and circumstances affecting the

entity during a period except those that

result from expenses or distributions to

owners"-Accounting Principles Board (APB)

Statement no 4 .

Nesse sentido, são determinantes principais do lu cro contábil os principios da realização e a regra básica do "matching", embora todos os demais princi pios e convenções contābeis geralmente aceitos influenciem direta ou indiretamente a apuraça do resultado da empresa.

b. 4. REALIZACÃO - estabelece o critério geral de reconhec mento da receita e assim o define O FASB - Concepts Statements nọ 3 :

"Realization in the most precise sense means the process of converting noncash resources and rights into money and is most precisely used 
in accounting and financial reporting to refer to sales of assets for cash or claims to cash"

Jā o Accounting Principles Board (APB) Statement nọ 4 assim o incluiu como principio de mensuracão:

"Realization: Revenue is qenerally recognized when both of the following conditions are met:

(1) the earning process is complete or virtually complete, and (2) an exchange has taken place".

Exceções à aplicação da regra:

a) reconhecimento do acrēscimo (accretion) - represen ta um aumento no valor de ativos como recursos flo restais por (crescimento) ou minerais (por descobertas);

b) percentagem de acabamento - que permite, no caso de contratos de construcão de longo prazo, o reconhecimento proporcional de receita, antes do tērmi no da obra. Um método alternativo é o reconhecimen to proporcionalmente aos custos incorridos.

c) reconhecimento da receita na producão - aplicavēl a metais preciosos com valor monetário fixo, sem custos significativos para sua colocacão no mercado. 
A Realização ē um dos princīpios determinantes do re sultado, cuja validade muito se discute, sendo muito criticado pelos economistas que, com muita razão,con sideram a formação da renda como um processo cumulativo, a partir da aquisicão das matērias primas e não apenas como decorréncia do ato da venda.

Jā em 1943, George 0 . May ${ }^{(7)}$ apontava as deficiências do Principio da Realizacão e a sua concordāncia com o ponto de vista dos economistas:

"Manifestly, when a laborious process of manufacturer and sales culminates in the delivery of the product at a profit, that profit is not atributable, except conventionally, to the moment when the sale or delivery ocurred. The accounting convention which makes such an atribution is justified only by its demonstrated practical utility".

A praticidade e a objetividade parecem ser os principais trunfos para a aceitação, hoje não muito pass $\underline{i}$ va, do princípio da realizacão, cujos efeitos distorcivos constituem-se num dos alvos principais das criticas.

b.5. 'MATCHING' - A mensuração de despesa é geralmente considerada mais dificil que a da receita, porque as vendas de bens e serviços são datadas, enquanto que muitas vezes isso não ocorre com as despesas. Daí a

(7) May, George 0. - "Financial Accounting", The MacMillan Co, 1943. P. 30 . 
introducão do critério do "matching" para o reconhec $\underline{i}$ mento de despesas, vinculando-o ao reconhecimento das receitas, pela utilizacão da relacão de causa e efeito - despesas são necessārias à percepcão de receitas, portanto, podem ser consideradas como causas da sua ocorrência.

0 reconhecimento de despesas pelo "matching" pode basear-se em associacão fĩsica (inventārios e mate riais), na decorrência de tempo (juros, seguros e depreciaça) ou na impossibilidade de medir futuros benefícios (propaganda e publicidade, donativos, pesqui sa e desenvolvimento).

A principal critica ao "matching" decorre sobretu do do fato de fazer com que a determinacão da despesa seja uma função das receitas, quando o razoāvel, segundo seus opositores, seria o seu reconhecimento independente. 0 pröprio Accounting Pinciples Board(APB) Statement no 4 (1970) explicitamente evita o termo, justificando:

"The term matching is often used in the accounting literature to describe the entire process of income determination. The term is also often applied in accounting, however, in a more limited sense to the process of expense recognition or in an even more limited sense to the recognition of expenses by associating costs with revenue on a cause and effect basis ... Because of the variety of its 
meanings, the term matching is not used in

this statement".

Em 1971, outro grande crítico do "matching", Robert T. Sprouse ${ }^{(8)}$ classificou-o como totalmente estéril.

\section{1,5,3. TENTATIVA DE CONCILIACÃO DE CONCEITOS}

David S: Solomons $(9)$, tentando especificar a distinção entre o conceito de renda económica de Alexander e a renda contábil, assim a expressou:

Renda Contābil

(+) Ganhos não Realizados nos Ativos Tangiveis

(-) Ganhos Realizados nos Ativos Tangiveis ocorri dos em periodos anteriores

(+) Alteracões no Valor dos Ativos Intangiveis

( ) Renda Econōmica

Em 1978, a Security and Exchange Comission (SEC)

fez uma exigēncia às companhias de petroleo, no sentido de publicacão de relatōrios suplementares baseados em conceito econômico-contäbil de renda, o método que ficou conhec do como o "Reservè Recognition Accounting"(RRA), o qual

(8) Sprouse, Robert T. - "The Balance Sheet - Embodiment of the most fundamental elements of Accounting Theory" - in Foundations of Accounting Theory, University of Florida Press, $1971, \mathrm{pg}$. 90/104.

(9) Solomons, David - "kconomic and Accounting Concepts of Income" - The Accounting'Review, July/1961,pg. $374 / 383$. 
consiste no cālculo do Valor Atual das reservas provadas de gās e petróleo, em um dado momento, usando os preços correntes de mercado de então e um fator de desconto anual de $10 \%$. Em consequéncia do questionamento da utilidade do demonstrativo suplementar, sua obrigatoriedade foi afrouxa da em 1981.

Numa das mais significativas tentativas de aproxi mar os conceitos económico e contäbil de renda, Edwards e Be $11(10)$ propuseram um conceito alternativo de renda, seme lhante à renda pelo custo corrente, que chamaram renda dos negōcios, assim como apresentaram um mētodo de ajustamento em face aos efeitos da alteracão do nível geral de precos. 0 modelo permite uma avaliacão separada dos resultados de decisões concernentes as operacões e daqueles decorrentes de decisões de manter ou não os ativos, abandonando assim o principio da realização. Comparando com o conceito contá bil convencional:

\begin{tabular}{|c|c|c|}
\hline \multicolumn{2}{|r|}{ Renda contābil } & Edwards e Bell \\
\hline Vend & & Vendas \\
\hline$(-)$ & $\begin{array}{l}\text { Custo Histörico dos Bens } \\
\text { Vendidos }\end{array}$ & $\begin{array}{l}\text { (-) Custo Corrente } \\
\text { Bens Vendidos }\end{array}$ \\
\hline \multirow[t]{2}{*}{$( \pm)$} & $\begin{array}{l}\text { Ganhos ou Perdas Realiza } \\
\text { dos na manutencão de At } 1 \\
\text { vos }\end{array}$ & $\begin{array}{l}\text { (士) Ganhos ou Perdas Reali } \\
\text { zados na manutencão de Ati } \\
\text { vos }\end{array}$ \\
\hline & & $\begin{array}{l}\text { (士) Ganhos ou Perdas não } \\
\text { realizados na manuten- } \\
\text { ção de ativos }\end{array}$ \\
\hline
\end{tabular}

(10) Edwards, Edgar 0. e Bell Philip W. - "The theory and Measurement of Business Income" - University of California Press, 1961. 
A propōsito das controvērsias sobre o conceito de renda a adotar, o grupo de estudo que debateu as mudancas nos conceitos de renda dos negōcios, em 1952, assim concluiu em seu relatōrio:

\footnotetext{
"Economists might disagree with the accounting view, accountants might agree with the economists that a gradual recognition of revenues on the basis of accretion might be preferable, but they might reject it as too seldom capable of implementation".
}

Decadas se passaram e permanece de pé o desafio da conclusão acima. Até quando?

\subsubsection{MENSURAÇ̃̃ E AVALIAÇ̃̃o}

Expressando a importāncia da mensuração, Lord Kelvin afirmou certa vez que, sem uma mensuração não se poderia ter o conhecimento completo de qualquer coisa. Em 1946, S.S. Stevens(11), um psicólogo, definiu de uma for ma simples mensuração como "a atribuicão de nūmeros a objetos ou eventos de acordo com regras".

Diferentemente da mensuração nas ciências exatas, a mensuração contábil encontra sērios obstāculos à sua consecucão satisfatōria, pois:

19. a determinação do atributo ou objeto a ser medido e a (11) Apud Kenneth,s. Most. "Accounting Theory". $2^{\text {nd }}$ ed, Grid Publ. Inc., Columbus, Ohio, 1979 , P. 238. 
forma de sua realização dependem dos inūmeros concei tos de renda e sua relevāncia;

20. a unidade de medida dos fatos e eventos contābeis, a moeda, geralmente não se reveste das características de invariabilidade desejāveis num padrão de medida, tra zendo problemas adicionais;

30. a restricão imposta pela convencão do conservadorismo, como uma reação prudente à incerteza e aos riscos a ela inerentes.

Os resultados da mensuração contābil informados aos usuários para a tomada de suas decisões devem ser prin cipalmente relevantes (utilidade preditiva), oportunos, ob jetivos e neutros.

Como atender integralmente a todos esses requisitos qualitivos, considerando o contexto em que a contabil $\underline{i}$ dade atua e ainda prover as informacões desejadas pelos tomadores de decisäo?

Atē o momento, embora em detrimento da relevāncia, os contadores, no seu conservadorismo, tem privilegiado a segurança da objetividade, na elaboração dos relatórios con tābeis destinados aos usuärios externos.

\subsubsection{INSATISFAÇ̃̃O EM RELACÃO A DEMONSTRACÃO DE RESULTADOS}

Embora as criticas não se restrinjam a esse demonstrativo, serão apontadas abaixo algumas críticas ao De monstrativo de Resultados, apesar dos esforcos que tem si- 
do feitos no sentido de melhorā-10:

10. falta de um conceito consensual de lucro liquido na teoria contābil e o problema do reconhecimento de receitas e despesas, em funcão dos principios e conven cões contābeis;

20. inabilidade de chegar a um consenso sobre as mudancas no nivel geral de precos e como relatā-los na demons tracão de resultados;

30. sua inutilidade para decisões de curto prazo;

40. ausência de dados físicos e de comportamento que poderiam tornā-la mais ütil para anālise;

50. falta de dados sobre os maiores clientes e informacões financeiras sobre āreas geogräficas

1.2. CONTROVÉRSiAS SOBRE A PUBLICACÃO DE DADOS PROSPECTI VOS

\subsubsection{NATUREZA DAS PREVISÕES}

Previsões decorrem da combinacão de julgamento e ciência, onde histōria, planos, reacões, aspiracões, limitacões e pressões tem uma influēncia. São baseadas em hipō teses da administracão sobre eventos futuros, alguns expli citos e outros implicitos, hipoteses essas por sua vez baseadas em situacões presentes e informacão interna e exter na disponiveis.

Como são afetadas por fatores como receitas, cus- 
tos, relacões trabalhistas, controles governamentais, impostos e condicões econōmicas gerais, não hä nenhuma seguranca de que os resultados previstos serão alcançados.

Informacões sobre o passado e o presente, bem como julgamento sobre a direção da mudança das condiçoes, são necessārios para a elaboração das estimativas, que podem não se confirmar no futuro, exigindo a revisão das mesmas, se as mudancas forem significativas.

A informação de previsões é substancialmente me nos passível de verificacăo objetiva, ao contrārio dos dados histōricos. Por outro lado, o usuärio deve estar sem pre ciente da inacurācia inerente a qualquer previsão(12).

Apesar do grau de risco da incerteza inerente a estimativa, a utilizacão crescente de modelos estatísticos, tem possibilitado o desenvolvimento de modelos preditivos que permitem avaliar a amplitude provāvel desse risco.

\subsubsection{POR QUE PUBLICAR DADOS PROSPECTIVOS?}

A Razão bāsica seria o fornecimento de informações mais relevantes para os usuärios externos, especialmente a cionistas, tendo em vista suas decisões relativas às expec tativas sobre o futuro da empresa. De outra forma, teriam

(12) Management Ndvisory Services Executive Committee, Guideline series no. 3 "Guidelines for systems for the preparation of Financial Forecasts" - AICPA, march/ 1975, p. $5 / 6$. 
que basear-se em informações convencionais publicadas, em projecões efetuadas por analistas de investimento e em outras fontes externas à empresa, mais passiveis de erras, quando ninguém melhor que a prōpria empresa poderia fornecer os dados prospectivos relevantes.

A publicação das previsões evitaria tambēm a possibi lidade de ocorrência de privitégios à pessoas "seleciona das" que gozariam de uma vantagem injusta relativamente aos demais usuārios.

\subsubsection{RESISTENCIAS À PUBLICACÃO DE DADOS PROSPECTIVOS}

Uma pesquisa efetuada, em 1972, pela "Financial Executives Research Foundation "revelou uma forte oposicão da Administracão das Empresas, que apresentaram os seguintes motivos:

- incorréncia em despesas adicionais para o "disclosure" de dados prospectivos;

- perda de certas vantagens competitivas pelo fornecimento de informacões importantes às concorrentes;

- preferéncia pelos dados condensados em confronto com 0 maior detalhamento desejado pelos usuārios externos para suas anāitises (custo maior para informação);

- inexistência de garantia de confiabilidade como compensação dos gastos efetuados;

- a possibilidade de perda de credibilidade como resultado da ocorrência de diferencas entre o real e o previsto; 
- a tendéncia natural de a administracão aumentar a amplitude de variacäo das previsöes, como medida de seguranca, diminuindo a utilidade das mesmas;

- resisténcia da auditoria face a necessidade de sua adequação a uma nova atribuicão: opinar sobre as estimati vas apresentadas.

Não obstante as objecões feitas pela Administra cão, recentemente, calorosas discussões sobre o "disclosure" de previsões de lucros, resultaram nas seguintes propostas: - o Grupo de Estudo sobre Objetivos dos Relatōrios Finan ceiros do AICPA (1973), debatendo a relação entre o processo preditivo e os objetivos dos relatōrios financei ros, recomendou que previsões financeiras fossem fornec das, quando fossem üteis no processo preditivo.

- a Security and Exchange Comission (SEC) anunciou, tambēm em 1973, que seria' permitida a inclusão de informa cäo sobre previsöes nos relatórios a ela destinados e, em 1975, propós a implementacão de tal informação.

- o "Accountants International Study Group" (1974) recomen dou um progresso ordenado, no sentido da publicaça de previsões de lucros $(13)$.

(13) Accountants International Study Group - "Published Profit Forecasts" - December 1974. 


\subsection{DILEMA DA CONTABILIMADE: PROGRESSO OU ESTAGMACÃO?}

\subsubsection{DINAMICIDADE DO CAMPO DE ATUAČ̃o DA CONTABILIDADE}

\subsubsection{CRITICAS ^̀ CONTABILIDADE}

A Contabilidade tem sido criticada, por contado res e não contadores, em função de muitas razões, entre as quais:

- é baseada nos irrelevantes custos histōricos ao invés de custos de oportunidade

- ela apenas provê os usuārios de uma descricão do passado, sem uma previsão do futuro

- seus modelos consistem exclusivamente de identidades e não permitem procedimentos de otimização

- ignora fatores psicológicos e usa procedimentos arbitrārios de alocação

- o balanco patrimonial não é suficientemente compreensivo porque o critērio de mensuracão para inclusão é excessivamente superficial

- que suas mensuracões não são acompanhadas de erros de es timação $(14)$.

Assim, embora a Contabilidade assegure a utilida-

(14) Mattessich, Richard - "Accounting and Analytical Methods - Measurement and Projection of Income and wealth in the Micro and Macro-Economy". Richard D. Irwin Inc., Homewood. 1964, p. 414. 
de seu produto aos acionistas, os relatórios financeiros pu blicados não mostram os lucros disponíveis para dividendos; da mesma forma, a utilidade pretendida para os credores $f j-$ ca prejudicada pela não demonstração dos valores correntes de mercado dos ativos e os onus sobre os mesmos; e, final mente, até mesmo para a legislacão fiscal há necessidade de adaptação para avaliacão dos impostos devidos.

\subsubsection{ATRASO RELATIVO DA CONTABILIDADE FINANCEIRA}

Apesar da evolução do conhecimento contäbil, conforme demonstra o gräfico $1.1^{(15)}$ abaixo, a Contabilidade F $\underline{\mathbf{j}}$ nanceira experimenta um atraso relativo, comparado à Contabilidade Gerencial, a qual livre das limitacões impostas pelos princípios e convencões contábeis tem sido uma fonte informativa de grande utilidade para a Administracão.

A urgēncia de adequação dos objetivos dos relató rios financeiros à realidade dinâmica do campo de atuacão da contabilidade è reconhecida pelo FASB, em 1978, em "Statement of Financial Accounting Concepts"(16):

"... the objetives of financial reporting are not immutable - they are affected. by the economic, legal, political, and social environment in which financial reporting

(15) Most, Kenneth - "Accounting Theory" - $2^{\text {nd }}$ - Grid Public. Inc., Columbus, Ohio, 1979, pg. 5 .

(16) Apud Welsch, Glenn A, Zlatkovich, Charles T. e Harrison, Walter T. Jr. - "Intermediate Accounting", 5 th ed. Richard D. Irwin Inc. 1979, p. 23. 


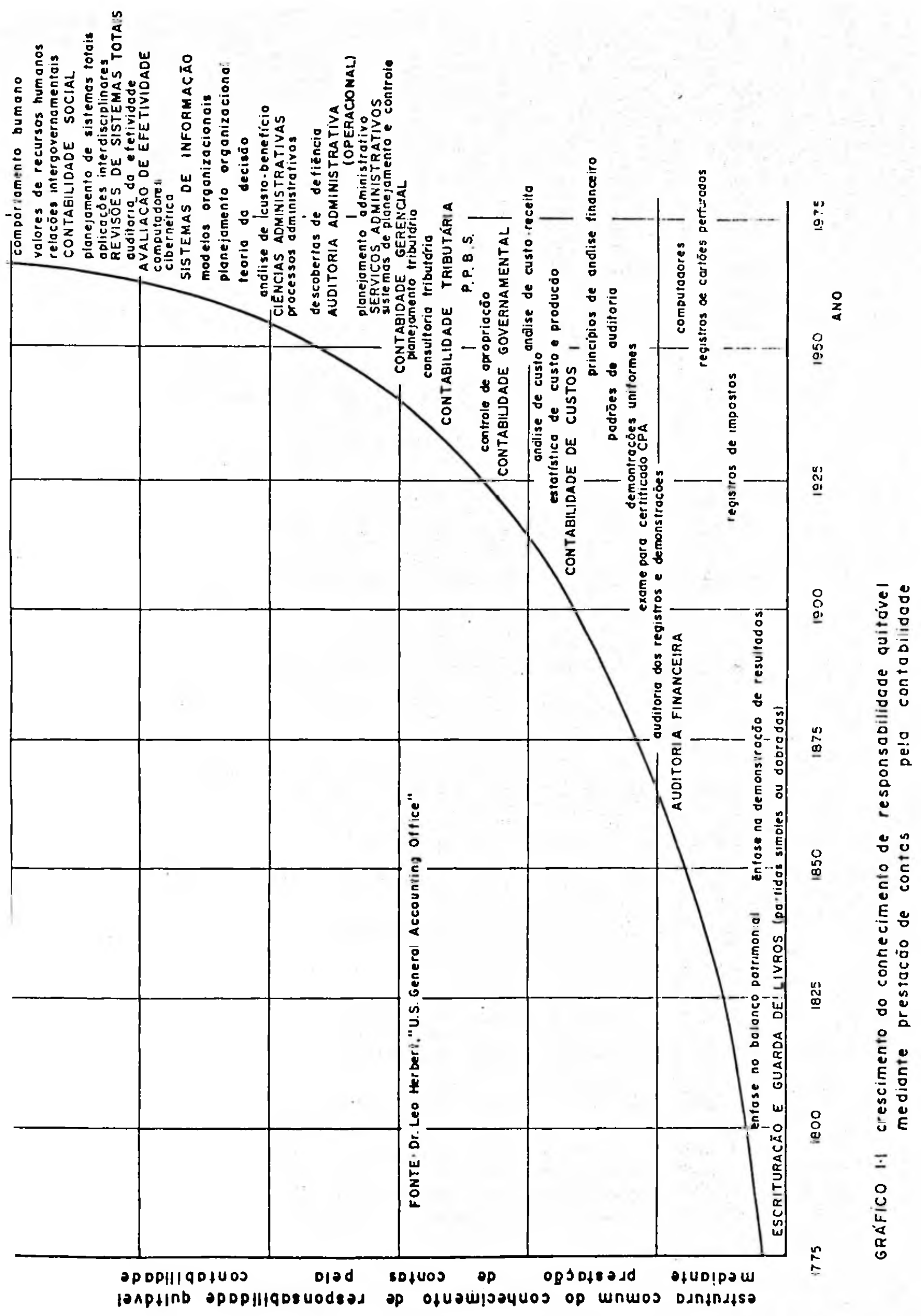


takes place".

Por outro lado, tais mudanças são ainda mais justificadas pelo fato de, atualmente os modelos de avaliacão dos dados contäbeis enfatizarem a habilidade preditiva dos mesmos, como o faz, por exemplo, Beaver, Kennelly e Voss (17), em "Habilidade Preditiva como um Critērio para a Avaliacão dos Dados Contābeis".

A realcar a importāncia das informacões contābeis, não só para os seus interessados usuais, mas tambēm para a prōpria comunidade, nos EUA, em 1974 e 1975, a Camara dos Deputados e o Senado Federal constituiram Comitê para investigacão da profissão contábil e dos relatōrios publicados.

1.3.2. EXIGENCIA DE ADEQUACÃO DA CONTABILIDADE COMO SISTEMA INFORMATIVO

1,3,2,1. FORNECIMENTO DE INFOMACÕS MAIS RELEVANTES PARA A TOMADA DE DECISÕES

Como jā foi abordado em objetivos dos Relatōrios Contābeis, a relevāncia dos dados preditivos, que fornecam uma visão das expectativas futuras sobre a empresa, é in-

(17) Beaver, William H, Kennelly, John W. e voss William M. - "predictive Ability as a Criterion for Evaluation of Accounting Data" in Hendrirsen, Eldon S. \& Budge, Bruce P. - "Contemporary Accounting" - Dickenson Publ. Co Inc. California, 197 p. 36/48. 
contestāvel para a tomada de decisões. E ninguēm melhor que a prōpria empresa para fornece-los.

1.3.2.2. NECESSIDADE DE ALTERAC.̃o DE ALGUNS PRINCIPIOS E CONVENÇÕES CONTÁBEIS GERALMENTE ACEITOS

Estando os Relatōrios Financeiros Publicados atados à observância rigorosa dos citados Principios e Conven cöes, alguns dos quais constituem-se em verdadeiros entraves ao progresso da Contabilidade, o atendimento integral da funcão informativa da Contabilidade, de forma mais satisfatōria, depende de revogacão ou reformulacão dos mes mos.

1.3.2.3. PROPOSTA DE REFORMULACÃO

Não $\bar{e}$ recente a iniciativa nesse sentido e inūmeros tem sido os estudos realizados em vārios países, pro pondo a reformulacão dos chamados Princípios e Convencões Contābeis Geralmente Aceitos, entre os quais pode-se citar:

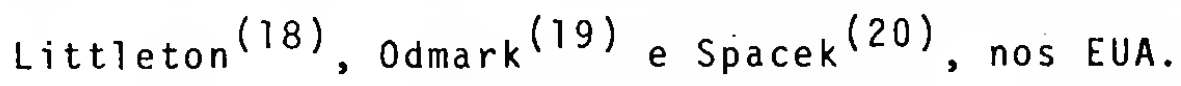

(18) Littleton, A.C. - "Suggestions for the Revision of the Tentative Statement of Accounting Principles"-The Accounting Review, Vol. $14 \mathrm{pg} .57 / 64$.

(19) Odmark, V.E. - "Current Challenges to Accounting Principles" - The Accounging Review april/1960, pg. $272 / 277$.

(20) Spacek, Leonard - "A suggested Solution to Principles Dilemma" The Accounting Review - vol.39 pg. 264/274. 
1.3.2.4. PRINCIPAIS ALVOS: CUSTO COMO BASE DE VALOR, DENO MINADOR COMUM MONETÁRIO, REALIZAÇÃO, CONSERVADO RISMO E OBJETIVIDADE.

Em "Contabilidade Introdutōria"(21), seus autores elaboraram o Quadro 1.1. abaixo transcrito, avaliando os Prin cîpios e Convenções Contābeis Geralmente Aceitos, bases da prätica contābil e determinantes do conteūdo das informa cões contábeis:

(21) Op.cit.pg. 271 . 


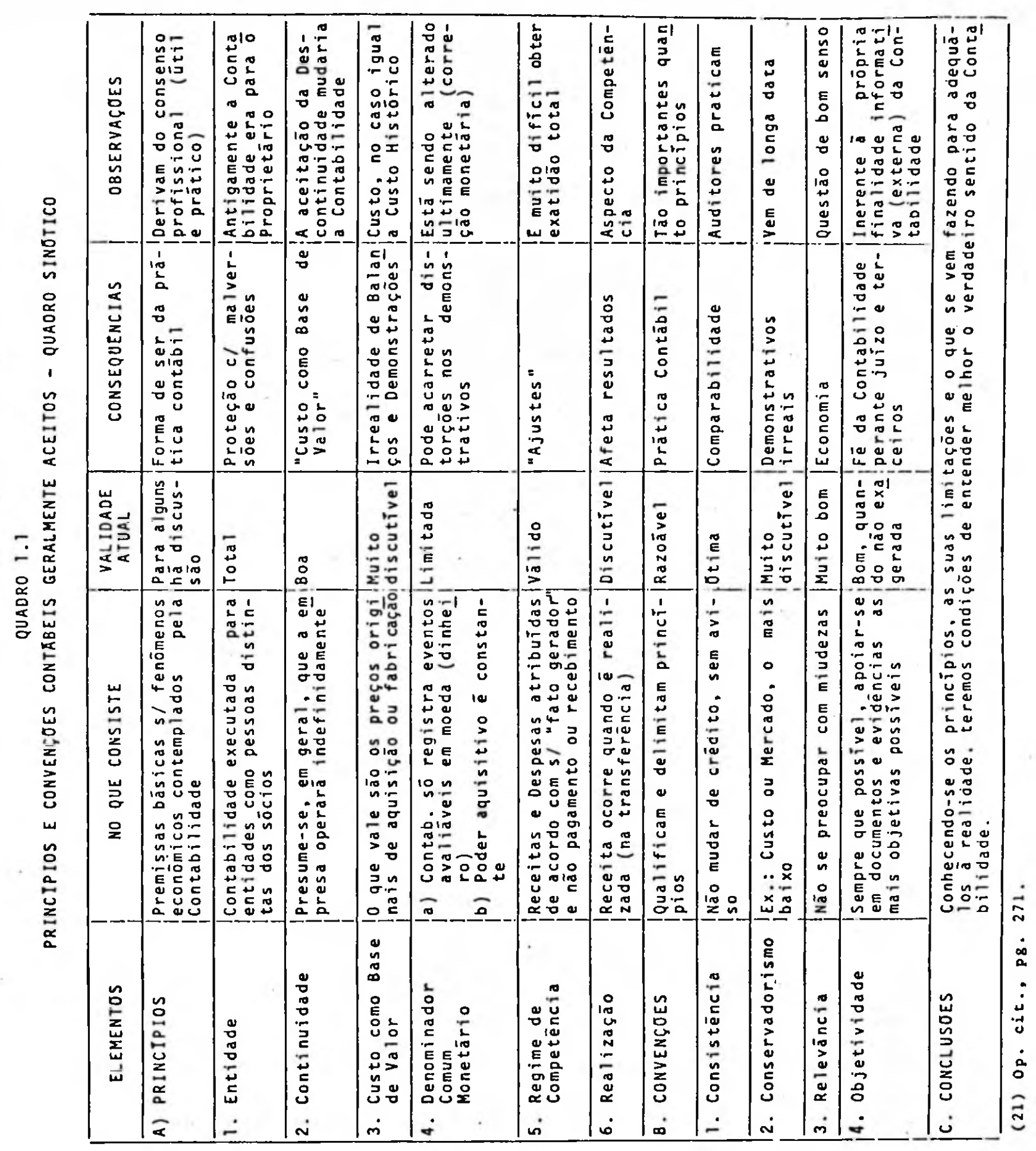


1.3.3. ORGÃOS QUE INTERVEM NO CAMPO CONTABIL.

1.3.3.1. AMBITO INTERNACIONAL

- "international accounting standards committee" (IASC) -

- organismo da profissão contābil, de carater internacio nal, criado em 1973 e tendo por objetivo:

a. formular e publicar no interesse público, as normas de contabilidade a serem observadas na apresentaça de demonstracoes financeiras e promover sua aceitacão e observāncia em àmbito mundial; e

b. trabalhar, em geral, pelo melhoramento e harmonizacão dos regulamentos, normas contábeis e procedimen tos relativos à apresentacão das demonstraçoes financeiras.

o IASC, portanto, como o próprio nome indica, visa basicamente a harmonizaça internacional da Contabil dade, influindo no desenvolvimento dos procedimentos con tábeis a nỉvel mundial, jā que seus membros se comprometem a aplicar todos os esforcos no sentido de implantar em seus paises as normas aprovadas pelo Conselho Dire tor do Comitê.

Até o presente momento, O IASC emitiu 24 pronun ciamentos acerca de procedimentos contábeis a serem observados internacionalmente.

- "international federation of accountants" (IFAC) - é o órgão de cúpula da profissão contābil no mundo, tendo si do criado em 1977, e visa desenvolver e aprimorar a profissão contábil, de forma internacionalmente coordenada, 
atravēs da harmonização das normas contābeis. Para consecucão desse objetivo, compõe-se de 7 comissões: Auditoria, Educacão, Etica, Contabilidade Administrativa, Organizacão Regional, Congresso Internacional e Planejamento.

A partir de 1987, segundo acordos assinados, haverá uma maior conjugacão de esforcos entre o IASC e a IFAC, para a consecução da harmonização e desenvolvimento da profissão contābil, cabendo à ūltima a indicação dos 13 membros que comporão o primeiro.

\subsubsection{COMUNIDADE EUROPÉIA}

A "Union Européenne des Experts Comptables Economiques et Financiers" (UEC), embora fundada em 1951 , somente pas sou a ser uma organização de àmbito verdadeiramente europeu, em 1963, sendo seus objetivos em termos gerais:

a. habilitar os contadores a contribuir mais efetivamente pa ra o desenvolvimento económico da Europa e a trabalhar pa ra a unidade européia;

b. elaborar os padrões de conduta e conhecimento profissionais e trabalhar para as suas harmonizacões em todos os paises filiados a UEC;

c. prover uma plataforma para o estudo e solucão dos proble mas da profissão contábil e a ela relacionados.

Para concretizar esses objetivos a UEC tem uma estru tura organizacional composta por uma Assembléia de Delega dos dos paises membros, uma Diretoria Executiva e uma Secre 
taria Geral. A elaboracão de estudos sobre assuntos especī ficos cabe aos 13 Grupos de Trabalho Permanentes, dividi dos em:

1. Grupos de Trabalho Científico e Técnico, compreendendo:

- Terminologia Contābil

- Legislação Contābil

- Auditoria

- Técnicas Contābeis

- Controle Orcamentārio e Administrativo

- Pesquisa Econōmica e Financeira

- Matemātica Financeira

- Contabilidade Pública

- Publicacões

- Pesquisa Tributāria

- Pesquisa Teörica e Histörica

2. Grupos de Trabalho Profissional, compreendendo:

- Educação Profissional

- Organização Profissional

Alēm dos relatōrios a respeito de suas atividades normais, os Grupos de Trabalho são responsāveis pela publicaçào de Dicionārios sobre Terminologia Contābil e Manuais de Auditoria, entre outras.

A UEC certamente $\bar{e}$ um ōrãão de importāncia funda mental, näo só para a profissão contābil na Europa,mas tam- 
bém porque a unidade européia fatalmente passarā pela uni ficação do pensamento e procedimentos contābeis no Velho Mundo.

\subsubsection{ESTADOS UNIDOS}

- "american institute of Certified public accountants", (AICPA), a associação dos auditores dos EUA, através de suas publicaçoes (Journal of Accountancy entre elas), dos "Accounting Research Studies" (ARS) e dos seus "Statements" tem influenciado muito os procedimentos con tábeis naquele país. Os "Accounting Research Bulletins" e o "Accounting Terminology Bulletin" (no periodo de 1938 a 1959) emitidos pelo Comite sobre Procedimentos Contābeis, as Opiniões e os "Statements" do "Accounting Principles Board" (no periodo de 1959 a 1973), que substituiu o Comitê e, finalmente os "Statements" do "Financial Accounting Standards Board - FASB" (a partir de ,1973), agora um órgão não mais constituido exclusiva mente de auditores, muito tem contribuido para o disciplinamento da prática contábil. Face a necessidade de maior amplitude nos debates preliminares aos "Statements", para melhor auscultar os reclamos dos usuários, os "meetings" foram abertos ao público a partir de 1978.

- "AMERICAN ACCOUNTINg ASSOCiation"(AAA), cujos membros são professores da ārea contābil e contadores das empresas e do governo, tem por finalidade o desenvolvimento da teoria contábil, atravēs do encorajamento e patrocinio de 
pesquisas contābeis. Publica o "The Accounting Review", uma revista mundialmente conhecida no meio contābil, e tem emitido tambēm "Statements", de carater mais normat $\underline{i}$ vo, sobre Principios Contäbeis, Teoria Contābil, entre outros assuntos.

- "Securities AND exChange COMission" (SEC) è um ōrgão governamental com autoridade sobre o disciplinamento do mercado de titulos nos EUA, entretanto, em geral, a Comissão pouco tem interferido na prātica contābil, con fiando na iniciativa dos örgãos representativos da profissäo contábil. Recentemente, no entanto, considerando que o interesse público não vinha sendo totalmente servi do, o SEC(22) impos o "Disclosure" de certos dados de custo corrente, no que foi acompanhado pelo FASB, que propōs o "Financial Reporting and Changing Prices" (1978) e com "disclosure" de dados sobre custo histórico corrigido ou custo de reposiçà corrente.

- "InTernal Revenue Service" (IRS), è o Imposto de Renda americano, que ao definir as condicões de dedutibilidade de despesas e estabelecer restricões sobre a utilização de sistemas de avaliacão de inventārios. - por exemplo:atē bem pouco tempo atrās o LIFO ou UEPS não era aceito pelo IRS - tem influēncia sobre os procedimentos contábeis.

\section{$1,3,3,4$, BRASIL}

Apesar do brilhantismo de algumas contribuicões, os correspondentes örgãos brasileiros, representativos da pró (22) "Accounting Sëries Release (ASR)" nọ 190, 1976. 
fissão contābil, ainda não tem o nỉvel de entrosamento al cancado nos EUA, em razão do fato de alguns serem relativa mente novos como o Instituto Brasileiro de Contadores-IBRA COM: (ex Instituto de Auditores Independentes do Brasil)e a Comissão de Valores Mobiliārios (CVM), a quem cabe não só a fiscalizacão permanente das atividades e servicos do mer cado de valores mobiliārios, bem como a normatizacão do sistema de informacões das companhias abertas, que só foi cria da em 1976, pela Lei $6.385 / 76$.

Entretanto, foi o Banco Central, atravēs de suas Resoluçōes, que antecipou a padronização de demonstrativos contábeis e a obrigatoriedade de auditagem de demonstrativos a serem publicados, mais tarde consolidados na Lei das Sociedades por Acões (Lei no 6.404/76), que introduziu uma sērie de inovaçoes nas präticas contābeis do país.

A Secretaria da Receita Federal, örgão administra dor dos Tributos Federais, vem de longa data influenciando os procedimentos contábeis, na medida em que a apuração dos Resultados Tributāveis nem sempre é extra-contābil como deveria sē-lo. São sobejamente conhecidos no meio contäbil suas Portarias, Instrucões Normativas, Atos Declaratōrios Normativos e Pareceres Normativos.

o Conselho Federal de Contabilidade, um örgão de classe por exceléncia, tem tido participação, principalmen te através da promocão de seminārios, palestras e cursos de formação e especialização.

Não poderia ser esquecida, entretanto, a relevānte contribuicão de orgãos como a Fundacão Instituto de. Pes 
quisas Contābeis, Atuariais e Financeiras - FIPECAFI, uma das poucas entidades de pesquisas e cursos avancados de es pecialização na ārea contābil, existentes no paĩs. 0 "Ma nual das Sociedades por Ações" por ela elaborado, um "best seller", tornou-se a bíblia dos contadores brasileiros.

Mais recentemente, 0 Instituto Brasileiro de Pesquisas Contābeis, Atuariais e Financeiras - IPECAFI, outra entidade de influēncia no meio contábil brasileiro, elaborou o estudo "Estrutura Conceitual Básica da Contabilidade", uma ampliação do capítulo sobre Princípios Contābeis do citado Manual.

1.3.4. CONTABILIDADE PREDITIVA: UM OBJETIVO ALCANÇÁVEL?

A necessidade da publicacão de dados preditivos parece ser um ponto pacífico, em funcão da sua relevāncia para os usuārios externos, mas como fazē-lo sem ter que es perar pelas alteracões estruturais exigidas na teoria contābil?

Uma solução possivel poderia ser o fornecimento de demonstrativos alternativos: um na forma convencional, de acordo com os principios e convencões, e outro com dados preditivos, com ressalvas de näo observāncia daqueles princípios e convencões.

Os dados preditivos poderiam ser complementados com o "disclosure" dos seus fundamentos, cálculos e probalidades, de forma a que o usuārio pudesse ajustā-los aos 
seus próprios modelos preditivos.

A solucão definitiva, entretanto, requererá, sem dūvida, a participação de toda comunidade contābill, profís sionais e estudiosos, bem como dos usuärios, para a refor mulação de alguns princỉpios e convencões contābeis atualmente vigentes. A inflexibilidade é incoerente com a reali dade em que atua a Contabilidade. 


\section{CAPITULO II}

GOODHILL: CONCEITOS E NATUREZA 


\section{CAPITULO II}

\section{GOODWILL: CONCEITOS E NATUREZA}

\subsection{DEFININCAOO DE ATIVO INTANGIVEL}

\subsection{1, ORIGEM DO TERMO E "DEFINICC̃O"}

Tangível originou-se do latim "tango"(tocar), sig nificando literalmente perceptivel ao toque. Contrário sen so, intangĩvel significa não perceptível ao toque, o que acarretaria a definicão de ativo intangivel como aquele que possui valor econōmico mas carece de substāncia física,i.ē, constitui-se de ativo sem existencia corpórea.

\subsubsection{IMPRECISÃO CONCEITUAL OU CLASSIFICAÇAO IMPRÓPRIA?}

A falta de substāncia física, entretanto, não tem sido utilizada como condicão, pelos contadores, para a separação entre Ativos Tangíveis e Intangiveis. Assim, Depōsitos Bancārios, Contas a Receber, Seguros e Títulos de In vestimentos, apesar de representarem direitos, portanto, na da corpōreos, têm sido classificados como Ativos Tangíveis.

Então, o que realmente caracteriza um Ativo Intan give 1 ?

Em resposta, alguns autores, como Hendriksen (23), tem procurado atribuir-lhe adicionalmente a caracteristica

(23) Hendriksen, Eldon S. - "Accountins Theory" - Richard D. Irwin, Inc. Homewood, Illinois, 1970, p. 424. 
de ativo cuja existéncia não pode ser desvinculada dos ativos tangĩveis - o que na verdade não corresponde a realidade de muitos ativos intangiveis, que podem ser alienados iso ladamente como, por exemplo, patentes e förmulas - enquanto outros, como Hatfield ${ }^{(24)}$, contornando o problema da imprecisão conceitual procura caracterizar ativo intangivel por enumeração dos assim classificāveis.

Não foi sem razão que o Prof. Eliseu Martins em sua "Contribuicão à Avaliacão do Ativo Intangîvel"(25)ao abordar o Ativo Intangivel (capitulo III), com muita proprieda de, começou-o por "Definicão (ou falta de)".

Embora näo tenham apresentado os critérios utiliza dos, Welsch, Zlatkovich e Harrison ${ }^{(26)}$ classificam os intangiveis nos seguintes grupos:

a. ativos correntes: caixa, direitos a receber, investimentos a curto prazo e pagamentos antecipados;

b. fundos e investimentos: investimentos em ações e debentu res ;

c. outros ativos: direitos a receber a longo prazo;

d. ativos operacionais ou fixos: patentes, franquias e good will

e. ativos diferidos: pagamentos antecipados (longo prazo).

(24) Hatficld, Henry Rand - "Accounting:lts Principles and problems"- D. AppleLon and Co., Lnc.,NY,1927, p.111.

(25) Martins, Eliseu - "Contribuicão à Avaliação do Ativo In tangivel" - Tese Doutoramento - FEA-USP, 1972, p. 53.

(26) Op. cit., pg. 515. 
2.1.2, GOODWILL UM INTANGÍVEL MUITO ESPECIAL

Embora alguns autores relutem ou atē the neguem(27) a condicão real de ativo, em funcão de suas características peculiares, o Goodwill enquadra-se, segundo a maioria, na classificação de Ativo Intangivel. Um intangível ainda desprezado pela Contabilidade, a não ser que uma transacão o traga a tona, tornando inevitável o seu reconhecimento e re gistro.

Some-se a essas caracteristicas especiais a forma de apuração do seu valor contabilizāvel (ligado à continuidade da firma, um "going concern value"), uma forma hoje sempre residual, bem como a natureza de que se reveste,abor dado com maiores detalhes no capitulo 2.3 .

Pode-se dizer assim, que se trata de um Ativo In tangivel Especial, distinto dos demais integrantes do seu grupo. 0 menos realizável dos Ativos e, segundo o prof. Iudicibus ${ }^{(28)}$, o mais intangivel dos intangiveis.

(27) Chambers, Raymond J. - "Accounting, Evaluation and Economic Behavior", Prentice Hal1, 1966 (pg. 211): "o goodwill não atende as condições de severabilidade e de nenhuma forma aumenta a adaptabilidade da firma". Spacek, Leonard - "The Treatment of Goodwill in the Corporate Balance Sheet" (pg. 37 e 40) diz näo querer incluir como um ativo no Balanço "o valor atual da diferenca entre lucros futuros descontados e os ativos a serem usados em produzir os lucros".

(28) Iudicibus, Sergio de - "Teoria da Contabilidade" - ed. Atlas $1980, \mathrm{pg} .197$. 


\subsection{CONCEITO E NATUREZA DO GOODWILL}

\subsubsection{RAZÕES DA PREFERENCIA PELO TERMO GOODWILL}

Antes de mais nada, cabe aqui um esclarecimento a respeito da preferēncia pelo termo "goodwill", utilizado em todo o decorrer do presente trabalho. Como bem observou o Professor Eliseu Martins(29) em sua jä citada tese, tem - se utilizado, no Brasil, de forma impröpria, o termo "Fundo de Comércio" como sinōnimo de "goodwill" - a impropriedade começa com a utilização do termo "fundo", cuja conotação é di versa da atribuida e termina com a vinculacão ao comércio, restringindo a sua abrangēncia conceitual. 0 magnifico ma nual das sociedades por Ações, "best seller" de consulta obrigatória de todo contador, ao estabelecer um roteiro para contabilizacão de acordo com a Lei nọ 6404/76 (Lei das Soci edades por Acões), introdutora de profundas inovacões nos procedimentos contābeis vigentes, também optou, infelizmente, pela utilização do termo "Fundo de Comércio" como equivalente do Goodwill.

Os estudiosos, entretanto, consagraram o "Goodwill" na sua versão original, pois como o "Feed-back", è um termo técnico sem correspondente versão adequada em portuguēs. Por outro lado, "Goodwill" tem um sianificado muito mais abrangente, como será visto nos itens seguintes, que o seu suposto sinōnimo "Fundo de Comércio".

(29) Op. cit. p. 55 . 


\subsubsection{REFERENCIAS HISTÓRICAS}

Segundo Carsberg( ${ }^{(30)}$, cujo artigo serā a base das referéncias a seguir, a primeira utilização conhecida do termo de origem inglesa "goodwill" ocorreu em 1571, conforme o "Oxford English Dictionary - Wills and Inventories of the Northern Counties of England" e, relacionava-se com ter ra: "I gyue to John Stephen... my whole interest and my good will of my Quarrell (i.ē, quarry)".

A partir dessa data atē o advento do estudo $\therefore:$ de Francis More, apresentado à "Chartered Accountants' Students" Society" de Edimburgo, Escócia, em 1891, a avaliação do Goodwill, seu aspecto crucial, permaneceu mais como matéria para decisões de Juizes nos Tribunais, muito embora Catlett e 01son (31) mencionem dois artigos sob o mesmo titulo "Goodwill", publ $\underline{i}$ cados no "The Accountant" em 05/04/1884 e 22/09/1888, cujos autores foram respectivamente, William Harris e J. H. Bourne, porém, abordando principalmente outros aspectos do goodwill. o primeiro, Harris, constatava que o problema do goodwill tor nara-se crescentemente significante apōs o surgimento das empresas organizadas sob a forma de Sociedade por Acões, na segunda metade do século XIX. Antes disso a maioria dos con

(30) Carsberg Bryan V. - "The contribution of P.D. Leake to the Theory of Goodwill valuation", Journal of Accounting Rescarch, Spring/1966, p. 1/15.

(31) Catlett. George R. e Olson, Norman O. - "Accounting for Goodwil1" - Accounting Research Study no 10. ICPA,1968, p. 10 e 38 . 
tadores restringia-se em concordar que o goodwill não deve ria permanecer muito tempo no Balanco. Já Bourne, cujo estú do foi o vencedor em uma competicão de ensaios entre estu dantes, patrocinada pela "Liverpool Accountants Students ' Association", em 1888, preocupava-se mais com o aspecto con ceitual do goodwill:

... the benefit and advantage accruing to an
existing business from the regard that its
customers entertain towards it, and from the
likelihood of their continued patronage and
support. Hence, it has no relation to a new
business, and is only applicable to one already
established" $(32)$.

A propósito daquele perīodo de escassez produtiva na literatura do goodwill, Preinreich(33), em seu artigo "The Law of goodwill", elabora um histōrico das decisões ju diciais e suas tendéncias, iniciando-o pela primeira conhecida, datada de 1620, atē a decada de vinte, mostrando atra vēs das decisões proferidas a mudança gradativa que se processava no enfoque judicial sobre o assunto. Partindo do goodwill relativo a terras, o Judiciārio foi ampliando a abrangēncia do termo goodwill, incluindo progressiva e suces sivamente o valor atribuível à localização do negōcio,à a(32), (34) e (35) Apud Bryan V. Carsberg - "The contribution" of P.D. Leake to the Theory of Goodwill Valuation" - Journal of Accounting Research, Spring/1966, p. 1/15.

(33) Preinreich, Gabriel A.D. - "The Law of Goodwil1", Accounting Review, december/1936 p. 317/329. 
fluência de clientela garantida, à marca e à continuidade da firma, atē chegar a um conceito bem prōximo do atual.

0 estudo de More foi o primeiro a abordar a questäo da avaliacăo do goodwill, estabelecendo como base para - seu cálculo o Lucro excedente ao retorno de $6 \%$ a.a. sobre os ativos tangiveis liquidos.

Em 1897, Dicksee (34) tambēm enfocou o assunto, porém de um ponto de vista mais do seu tratamento contābil, defendendo a sua baixa imediata contra reservas de capital, entretanto, sugeriu além disso que a avaliação do goodwill deveria ser baseada no lucro restante, após a atribuicão de uma justa remuneracão da administracão e um retorno nor mal sobre o tangivel empregado. Ao lucro liquido assim apu rado, aplicar-se-ia um fator variável de acordo com a atividade da firma transacionada para a obtencão do goodwill.

Edwin Guthrie ${ }^{(35)}$, em uma conferencia proferida em 1898, explicava como ajustar o lucro líquido de um negōcio para obter uma base apropriada para a avaliaça do goodwill, capitalizando para isso o "lucro restante" de Dicksee, mediante aplicacão de taxa de juros adequada. Utilizando-se de exemplos muméricos para ilustrar as idéias desses auto res, Carsberg concluiu que as formulacões de Dicksee e Guthrie levariam a um valor idēntico para o goodwill.

0 que se tornou conhecido como o "Método de Nova Iorque"(1906), resultou dos problemas de avaliacão nas in meras demandas judiciais e não diferia muito das contribuj cöes anteriores, mas marcava o comeco do dominnio americano 
no assunto. 0 método propos a determinação dos lucros $1 \hat{i}$ quidos pela média dos lucros passados, após deducão de uma remuneração razoável para administracão e de um retorno de $6 \%$ a.a sobre os ativos tangiveis. 0 fator multiplicativo aplicāvel, tal qual recomendava Dicksee, seria variāvel de acordo com cada caso específico.

Henry R. Hatfield (1909), professor de Contabilidade da Universidade de California, percebendo que o valor de mercado do goodwill de um negōcio dependia do montante dos super-lucros, do grau de certeza da sua transferéncia ao comprador e do tempo de duracão esperado para os benefí cios, propós duas abordagens diferentes para a avaliacão do goodwi11:

1a. capitalizar os lucros liquidos deduzidos apenas da remuneraçäo da administração, obtendo-se dai a avaliação "going concern" da empresa como um todo. 0 goodwill re suttaria da diferenca entre o valor da empresa e o valor contābil dos ativos tangĩveis.

2ạ. capitalizar o "lucro resultante" apōs a dedução tambēm do retorno sobre ativos tangiveis.

Esses métodos de avaliação propostos constituĩram em real avanco relativamente aos precedentes.

A contribuicão de Leake, o real objeto do artigo de Carsberg, consistiu na apuração do goodwill atravēs da somatōria dos valores atuais dos super-lucros anuais (lucros liquidos deduzidos de remuneracão adequada da administra cão e de retorno normal sobre ativos tangiveis). Estes 
super-lucros seriam decrescentes, jā que a sua existēncia tornaria atraente o ramo de atividade onde ele estivesse $\underline{0}$ correndo, o que provocaria a afluencia de novas firmas ao ramo e a sua consequente diminuicão gradativa.

Catlett e 01 son citam ainda, intercalando-se às referēncias de Carsberg, um artigo publicado no. "The Accountant", em 1902, de autoria de E. A. Browne, "Goodwill: Its Ascertainment and Treatment in Accounts", onde o autor defendia a baixa do goodwill contra Lucros Retidos/Acumula dos.

Embora artigos de revistas especializadas e compéndios de Teoria da Contabilidade e Contabilidade Finan ceira tenham contemplado o goodwill em variados enfoques, 0 primeiro livro citado abordando especificamente o goodwill e outros intangiveis foi o de J.M. Yang, de 1927.

A partir da decada de quarenta, örgãos especializados como o AICPA (1944) e, mais tarde, O AAA, encamparam a preocupacão com esse assunto polémico e ao mesmo tempo importante, dai resultando os "statements" e estudos.

\subsubsection{EVOLUÇÃO CONCEITUAL E NATUREZA DO GOODWILL}

Acompanhando a evolucão dos sistemas económicos, inicialmente tendo sua base no dominio da terra, a fonte da riqueza da economia, posteriormente centrando essa base no comércio e finalmente na indūstria, o conceito de goodwill foi se modificando em funcão das rāpidas transformacões que se sucediam na economia, que culminaram na jā conhecida Re 
volucão Industrial.

Não sendo o objetivo deste trabalho a anālise detalhada da evolucão conceitual, sua abordagem, para efeito de simplificacão, serä subdividida em:

\section{2 .3 .1 , CONCEITOS ANTERIORES DE GOODWILL}

Após sua primeira aparicão que se vinculava à ter ra, o goodwill foi gradativamente sendo relacionado com o comércio e finalmente com a atividade industrial. Dessa for ma, Lord Chancellor Eldon, citado por Preinreich ${ }^{(36)}$, as sim definiu o goodwill, em sua famosa decisão de 1810 (Crutwe $11 \times$ Lye):

"is nothing more than the probability that the old customers will return to the old place".

Em 1880, Lord Macnaghten (Ginesi $\times$ Cooper) ampliava o conceito de goodwill para:

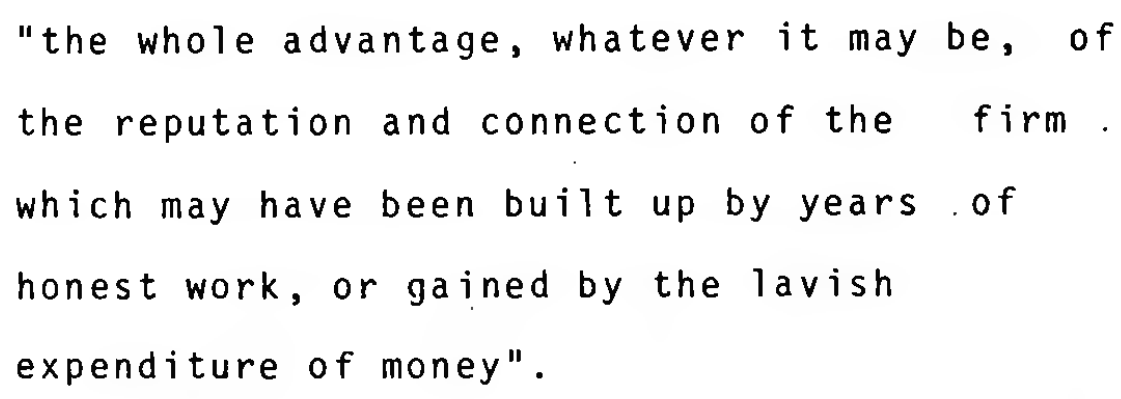

No mesmo sentido, J. H. Bourne, citado no item anterior, em sua definicão vinculava o goodwill a fidelidade da clientela em um negōcio jā estabelecido. (36) op. cit.p.317 c 318. 
Com o desenvolvimento industrial e a crescente complexidade que passou a caracterizar os negōcios, a lu cratividade das empresas deixou de ser atribuivel apenas a localizacăo privilegiada, a clientela garantida ou à per sonalidade dos proprietārios da firma. Processos industrais, conexões financeiras e "staffs" eficientes passarama desempenhar um papel importante na lucratividade de uma empresa e consequentemente a constituir parte substancial do valor do goodwill.

\subsubsection{CONCEITOS MAIS ATUAIS DE GOODWILL}

a. Conceito de Goodwill relacionado com capacidade de lucro

São conceitos ma is abrangentes de goodwill, englo bando todos os tipos de goodwill anteriormente abordados, os quais poderiam, segundo yang $(37)$ ser agrupados, de acordo com as vantagens económicas propiciadas, em:

a) aoodwill dos consumidores ou decorrente.da clientela es tabelecida,

b) goodwill industrial ou resultante da lealdade e adaptabilidade dos empreg̣ados e

c) goodwill financeiro ou decorrente das facilidades de obtenção de fundos.

George T. Walker ${ }^{(38)}$ relaciona o valor do goodwill à capacidade de lucro acima da normal:

(37) Apud Goorge R. Catlett c Norman 0. Olson - "Accounting for Coodwill" - Accounting Resedrch Study n? lo, AICPA, $1968, P .13$.

(38) Walker, George T. - "Why purchase Goodwill should be Amortized on a Systematic Basis", Journal of Accountancy. February 1953, p. 213. 


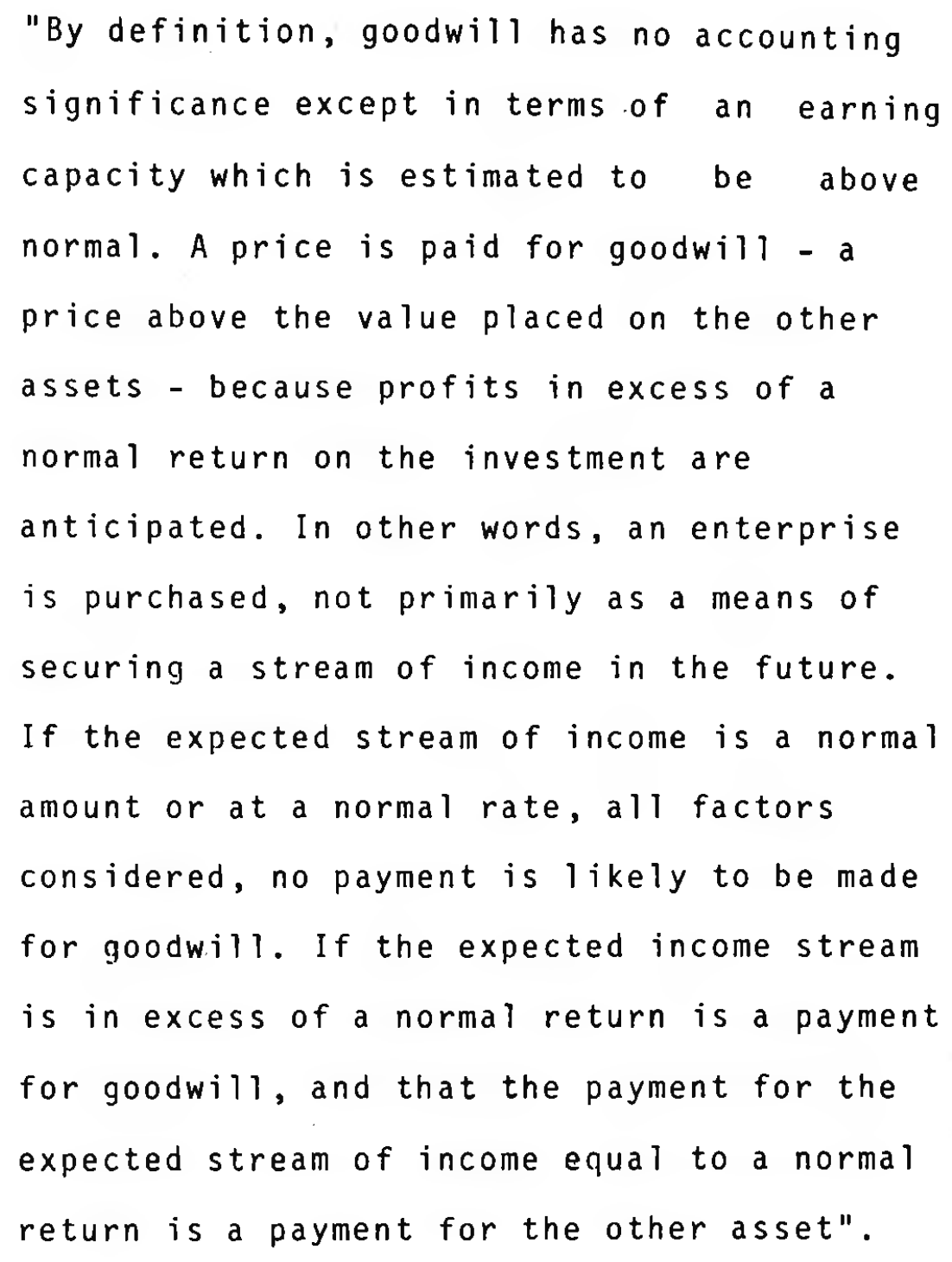

1. eficiēncia da administração nos seus diversos niveis e segnentos

2. processos industriais

3. propaganda e publicidade eficientes

4. localização estratégica

5. condicões tributārias favoráveis

6. boas relacões trabalhistas 
7. conexões financeiras privilegiadas

8. adequados treinamentos para empregados

9. boas relacōes com a comunidade

b. Goodwill como um Ativo dos Proprietārios da Empresa

Raymond J. Chambers considera o goodwill mais um ativo dos proprietārios de um negócio que um valor atribuㅍ vel a empresa em si:

"...the goodwill of a going concern runs to the constituents not to the firm. It is they who put valuations on expected superior returns. It is they who have the right to dispose of going concerns or of their interests in them. To regard goodwill as an asset of a going concern is to confuse two entities - the constituents accept an offer for a going concern in excess of the current cash equivalent of its capital, the difference is simply a gain of them. It arises only when the firm ceases to be the same firm by becoming the instrument of a new group of constituents. The new constituents, having laid out a sum in excess of the current cash equivalent of the old firm's components, may regard the advantage acquired as an asset of the new firm. But this excess, though represented by a money payment, is no 


\begin{abstract}
different from the amount by which. the subjective valuation of any sing̣le asset exceeds the price paid for it; and no such excess is regarded as part of the current cash equivalent of an asset. That cash has been paid may be recognized in the record; but its effect is in no way to increase the adaptability of the firm, and the indicated treatment of it is to reduce the amount of the residual equity from the price paid to the current cash equivalent of the new firm's component assets and liabilities"(39).
\end{abstract}

Embora atualmente algum consenso jä Exista em rela cão ao aspecto conceitual do goodwill ainda falta muito para contradizer a afirmação de Canning $(40)$, em 1929, de que "contadores, escritores da literatura contäbil, economistas. engenheiros e as cortes, tem tentado definir goodwill, discutir sua natureza e propor meios para avaliā-lo. A ma is interessante caracteristica dessa imensa quantidade de escritos é o seu nūmero e a variedade dos desacordos alcancados". Um dos problemas subsistentes continua sendo a linha divisória entre o valor atribuivel ao goodwill e aqueles atribuiveis a outros intangiveis, o que acarreta especialmen te dificuldade na sua mensuração.

(39) Clambers, Raymond J. - "Accounting. Evaluation and Economic Behavior". Prentice-Hall Inc.,1966,p.209/222.

(40) Canning John B. - "The Economics of Accountancy" - The Ronald Press Co., 1929, p. 38. 
Welsch, Zlatkovitch e Harrison (41) distinguem 0 valor de continuidade ("yoing concern value") da empresa do valor do seu goodwill, considerando que este ültimo se relaciona com a lucratividade acima da normal, enquanto 0 primeiro estaria ligado à capacidade normal de lucro. Reco nhecem, entretanto, a dificuldade de efetuar a sua separação".

A maioria dos autores, entretanto, concorda atual mente em que o goodwill é uma resultante do valor de empre sa como um todo, em termos de sua capacidade de geracăo de lucros futuros, e do valor econōmico dos seus ativos ident ficados e contabilizados.

Relativamente a natureza do goodwill, as correntes existentes podem ser agrupados em quatro grupos:

19. o grupo que vincula a sua natureza ao conceito de goodwill como valor atual dos super-lucros - uma corrente que atualmente perde importāncia jā que nenhum esforco $\bar{e}$ feito para identificar a contribuicão dos outros ati vos para a obtencão dos lucros esperados.

20. aquele segundo o qual o goodwill é uma resultante dos ativos não contabilizados e/ou sub-avaliados, seja em funcão do valor de mercado ou seu valor de uso. Entre os ativos não contabilizados poder-se-ia citar: proces sos e patentes prōprias, marca, localizacão, recursos humanos eficientes, linhas de crēdito favorāveis, fornecedores em condicões privilegiadas e lealdade de con

(41) 0p. cit. p.515. 
sumidores.

30. outro combina o valor de continuidade (going concern) da empresa e dos ativos não contabilizados e/ou sub-avaliados como responsāveis pelo goodwill - trata-se do grupo do "master valuation account". Corresponde na verdade a um expediente para contornar a quase imposs $\underline{\mathbf{i}}$ bilidade de identificar certos componentes do goodwill e de medir outros identificāveis. A aceitação dessa linha de pensamento implica no reconhecimento de que o goodwill é um "valor conjunto" que não pode ser dissociado e atribuido a ativos individuais.

40. o ültimo e mais recente é aquele que, segundo Bedford e Burton(42), acredita ser o goodwill uma resultante do fenomeno da sinergia. Portanto, o goodwill não è um ativo independente como um ativo tangível qualquer,que pode ser vendido ou trocado. Ao conträrio, trata-se de um valor ligado a continuidade da empresa, representan do o excesso do valor dos ativos combinados da mesma sobre a soma dos seus valores individuais.

O goodwill, em sua natureza, $\bar{e}$ um valor decorrente da expectativa de lucros futuros edacontribuicão atribuível aos ativos não identificados e/ou não contabiliza dos pela empresa, bem como a sub-avaliação dos ativos e até métodos de mensuração. E um valor residual atribuível entre outros fatores à existēncia de administracão efici-

(42) Bedford, Norton M c Burton, E. James - "Goodwill" in Dilvidson, sidncy \& weil, Roman L., "llandbook of modern Accounting", Mc-Graw-llill Co, 1977, p. 21-2. 
ente, processos industriais e patentes pröprios, localizacão ótima, recursos humanos excelentes, efetividade da propaganda e condicões financeiras privilegiadas e do grau de sinergia, fatores importantes para a empresa, mas näo contemplados pela contabilidade, em função da dificuldade de sua mensuração. Acabam todos incorporados ao valor do goodwill quando a empresa è vendida.

Assim, o goodwill difere dos demais ativos ident ficāveis e separāveis que podem ser transacionados individualmente, pois tem a sua existéncia vinculada a existēn cia da firma, dela não podendo ser separada e vendida.

\subsubsection{GOODWILL SEMPRE UM CONCEITO RESIDUAL?}

A evolução conceitual por que passou o goodwill não lhe tirou o caracter residual do seu valor, decorrente sobretudo da forma de sua apuração. No decorrer do tempo,o que tem mudado como resultado dos diferentes métodos utili zados, é a natureza e a importāncia do valor residual correspondente ao goodwill.

Assim, no caso do goodwill relacionado com superlucros, seu valor resultava da diferenca entre os super-lu cros e os lucros normais da empresa - diferenca sobre a qual era aplicada uma taxa de desconto para o cálculo do seu valor atual. Por outro lado, o goodwill avaliado pela diferenca entre o valor da empresa como um todo, em termos de capacidade potencial de produzir lucros futuros, e o valor dos ativos identificados e contabilizados, enfatiza 
a correspondēndcia do resíduo aos ativos não contemplados pela contabilidade - o conceito residual propriamente dito do goodwill, segundo Paton. Qualquer que seja a forma e ava liação dos citados ativos - custo histōrico, custo de repo sição, valor líquido de realizacão ou valor económico ou de uso - e mesmo que o progresso da ciência restrinja gradativamente os ativos não contabilizados, pode-se afirmar que o goodwill não deixará de ter o seu caráter residual.

Segundo Reg S. Gynther ${ }^{(43)}$, face a sua natureza, se todos os ativos fossem identificāveis e contabilizāveis, não haveria goodwill:

"If we were omniscient it would be possible
to name all of intangible assets (as well as
the tangible assets) and to calculate for
its net present value. This would mean that
we would also have values for all assets such
as special skill and knowledge, high managerial
ability, etc-i.e. if they existed. There
would be no goodwill item as such". (Grifo deste)

Tal afirmação seria verdadeira apenas se a soma dos valres econômicos dos ativos fosse sempre igual ao valor da empresa - i.ēe, se fosse descartada a possibilidade de ocorréncia de sinergia na empresa, o que será abordado em 2.2.5.

(43) Gynther, Reg. S. - "Some conceptualizing on Goodwill i" in Hendriksen. Eldon. S. \& Budge, Bruce P. "Contemporary Accounting theory", Dickenson Publ. Co, California. 1974 . P. $220 / 231$. 


\subsubsection{GOODWILL NEGATIVO OU BADWILL}

Dadas as caracteristicas jā analisadas do goodwill, é possível a ocorrência de um valor negativo, nos casos em que o valor atual dos lucros futuros da empresa fosse menor que o valor econömico dos seus ativos. Tratar-se-ia do chamado goodwill negativo ou badwill, não muito enfocado pelos autores.

Nessa situacão, a empresa valeria mais pelos ati vos que pelas perspectivas de lucros futuros. Aos seus proprietários seria mais vantajoso liquidar os ativos a vender a empresa, enquanto para os compradores em potencial isso poderia significar um fator ponderāvel na aquisicão, jā que as condicões desfavorāveis determinantes da situaça da empresa podem ser sanāveis por uma nova administracão, como muito comumente tem ocorrido.

0 APB opinion nọ 16 manda, no caso de apuração de goodwill negativo, proceder a uma nova avaliacão dos ativos tangiveis e intangiveis adquiridos, de forma a não reconhecer goodwill negativo na contabilidade.

\subsubsection{CONCEITO IDEAL: GOODWILL SINERGISTICO}

Mesmo que todos os ativos tangiveis e intangiveis sejam identificados e mensurados os seus valores econômicos ou de uso, ao contrārio do que afirma Gynther, restaria o efeito sinergístico resultante da combinaça dos ativos ut lizados no processo operacional. 
0 que seria sinergia?

Sinergia è um termo de origem grega syn (com) e ergos (trabalho) que significa literalmente trabalho con junto. Segundo Bertoletti ${ }^{(44)}$ : "Existe sinergia quando duas ou mais causas produzem, atuando conjuntamente, um efeito maior que a soma dos efeitos que produziriam atuando individualmente...quando existe sinergia o todo è maior que a soma das partes".

Adaptando o conceito acima para a avaliaça de ativos: ocorrendo sinergia positiva, o valor da empresa se ria sempre maior que a soma dos valores econōmicos de todos os ativos utilizados, sem excecão. Assim, se o conta dor fosse omniciente, o goodwill resultante seria atribuível à sinergia da organização, um conceito muito mais ūtil para a avaliação do comportamento da empresa e suas potencialidades.

Entretanto, assim como o valor do goodwill conven cional é afetado por variacões conjunturais nas expectativas de lucros futuros, tambēm a mensuracão do goodwill sinergistico pode sofrer influencias distorcivas. A apuraça de um goodwill sinergístico isento dessas distorcões, seria conseguido na medida em que se pudesse eliminar as influéncias dos fatores não atribuiveis a sinergia propria mente dita.

(44) Bertoletti Mario E. - "Sinergia: Un Concepto de Alta Estratégia" - Rev. Administración de Empresas, vol.I, p. $315 / 319$. 
Obtida esșa "depuração" do goodwill sinergistico, este poderia constituir-se num verdadeiro termōmetro da eficiência da empresa em combinar os ativos utilizados.

\subsection{VALOR DO GOODWILL E SUA RELEVANNCIA PARA OS USUARIOS}

Qual a razão da relevāncia da informação do valor do goodwill para os usuärios, especialmente acionistas e acionistas potenciais da empresa?

Como foi extensamente abordado, o valor do goodwill de uma empresa, seja na sua forma convencional ou na forma definida como sinergỉstico, estará sempre relacionado com a capacidade de geração de lucros dessa empresa. Nesse sen tido, o seu conhecimento é de importância fundamental para a tomada de decisões concernentes à empresa. Da mesma forma, as informaçoes sobre o comportamento passado da empresa sō são importantes na medida em que propiciam uma projé cão da sua situação futura.

Um dos grandes problemas relativamente à avalia ção do valor do goodwill é a definição de quem deve fazē 10: cada usuärio de acordo com os seus interesses e com ba se nas informações disponĩveis sobre a empresa, publicados ou não, ou a prōpria administração da empresa, que tem meihores condições para uma mensuração mais precisa. A respeito D. R. Ladd $(45)$ a firma:

(45) Ladd, D.R. - "Contemporary Corporate Accounting and the Public". Richard D. Irwin Inc. 1963 p. 155. 
"The essential fact is that management because of the information it has, is in the best position to estimate the present worth and thereby the value of intangible resources of the corporation. Furthermore, it would be an important function of the public accountant to test the reasonableness of management. estimates, utilizing his knowledge of the particular corporation, his ability to compare estimates with those made by other clients, and a knowledge of business conditions generally. The characteristic coution of most accountants should act as an antidote to either excessive optimism or excessive pessimism".

A a firmação acima implica tambēm em modificaçōes nos procedimentos atuais de auditoria, jā que a esta seriam atribuidas adicionalmente as tarefas pertinentes a ra zoabilidade das estimativas feitas pela empresa.

De qualquer forma, a tendência $\bar{e}$ o crescimento gra dativo da importāncia do goodwill, na medida em que os at $\underline{j}$ vos não identificados e/ou contabilizados vão aumentando proporcionalmente aos demais ativos, com a sofisticação dos negōcios. Um rāpido exame nos fatores responsāveis pela capacidade de lucro de uma empresa, em 2.2.2, confirma tal afirmativa, já que a maioria deles, embora incontestāvel a Participação no sucesso de uma empresa, não é objeto dos registros contābeis. 


\section{CAPÍTULO III}

MENSURACÃO E CONTABILIZACÃO DO GOODWILL 


\section{CAPÍTULO III}

\section{MENSURAÇ̃̃O E CONTABILIZACÃO DO GOODWILL}

\section{3. ]. VALOR DO GOODWILL: UM DEPENDENTE}

\subsubsection{FATORES ENVOLVIDOS NA AVALIAÇÃO DO GOODWILL}

Na moderna conceituacão do goodwill, onde o seu va lor corresponde a diferenca entre o valor atual da empresa como um todo, em termos de capacidade de geracão de lucros futuros, e o valor económico dos seus ativos, pode-se afirmar a sua dependēncia de:

a. estimativa dos lucros futuros esperados da empresa,

b. identificacăo e mensuração do valor economico dos seus ativose, finalmente,

c. taxa de descontos ideal a utilizar para a apuracão do va lor atual.

São trēs variāveis independentese crīticas que determinarão, pela sua variacão, o comportamento da varíavel dependente (o goodwill da empresa). Isso mostra a vulnerab $\underline{i}$ lidade do valor apurado. Entretanto, hä que se considerar que as informações relevantes sobre o futuro jamais poderão se cercar da certeza dos fatos passados, caso contrārio,não seria necessāria a ciēncia administrativa e nenhuma impor tāncia teriam as projeções estatísticas. 
3.1.2. FORMAS DE AVALIAÇÃO DO GOODWILL

3.1.2.1. AVALIAÇÃO BASEADA NO LUCRO LIQUIDO E FATOR MULTI PLICATIVO

Entre os preconizadores mais antigos dessa forma de avaliação estavam Francis More, Lawrence R. Dicksee, Edwin Guthrie e o Método de Nova Iorque, cujas formulações pouco di feriam entre si, conforme exemplos numéricos apresentados por Carsberg( ${ }^{(46)}$, alguns dos quais estão transcritos abaixo:

a. LAWRENCE R, DICKSEE

Lucro Liquido .................... 23.500,

(-) Remuneração da Administração .... 500 ,

Juros sobre Capital Imobilizado

em Ativos Tangiveis: $8 \%$ a.a. de

$100.000 \ldots \ldots \ldots \ldots \ldots \ldots \ldots \ldots .000, \underline{8.500}$,

( $)$ Lucro. Liquido Ajustado ........... 15.000,

(x) Fator Multiplicativo de acordo

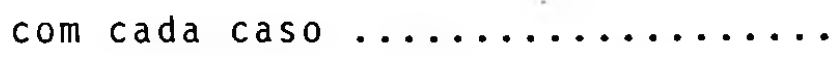

( =) Valor do Goodwill ............. 60.000

Algebricamente a formulação poderia ser expressa co mo segue:

$$
G=(L L-R A-i \cdot A T) \cdot F
$$

onde: $\quad G \ldots \ldots$ V. valor do Goodwill

LL ........Lucro Lĩquido

(46) op. cit.p. 5/10. 


\section{RA...... Remuneração da Administração \\ i ..... Taxa de Juros Aplicāveis ao Capital Imo bilizado em Ativos Tangiveis \\ F ...... Fator Multiplicativo para Obtencão do Goodwill}

b. MÉTODO DE NOVA IORQUE

Lucro Lĩquido (mēdia 5 anos) ............ 20.500,

(-) Remuneração da Administração ...... 500 ,

Juros sobre Capital imobilizado em

Ativos Tangiveis: $6 \%$ a.a. de

$100.000 \ldots \ldots \ldots \ldots \ldots \ldots \ldots \ldots \ldots \ldots \ldots \ldots, 6.000$,

(=) Lucro Liquido Ajustado ............ 14.000,

(X) Fator Multiplicativo de acordo com

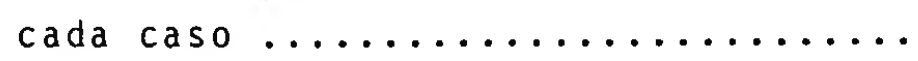

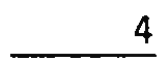

(=) Valor do Goodwill ............... 56.000,

Praticamente não difere do "modelo" de Dicksce. exceto pelo Lucro Líquido que passa a ser a média dos 5 ūitimos anos.

\subsubsection{2: MÉTODO DE HATFIELD}

Foi o precursor do método residual atualmente aplicado, tendo introduzido à época uma inovacão nos métodos de avaliacão do goodwill. Ainda de acordo com as ilustracões numēricas de Carsberq, sua avaliacão consistia em: 
Valor do Negócio (capitalização de 23.000

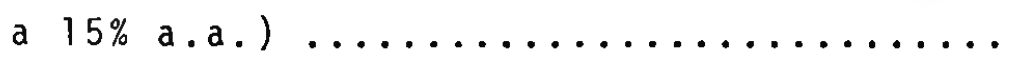

(-) Valor Contābil dos Ativos Tangíveis..

100.000 ,

(=) Valor do Goodwill, correspondente

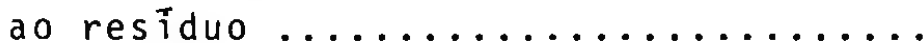

A expressão algébrica poderia assim ser representa da :

$$
G=\frac{L L-R A}{j}-A T
$$

onde: $L L \ldots . .$. Lucro Lĩquido

$$
\begin{aligned}
& \text { RA } \ldots \ldots \text {.... Remuneração da Administracão } \\
& \text { AT } \ldots \ldots \text { Ativos Tangiveis } \\
& \text { j } \ldots \ldots \text { Taxa de Capitalizacão dos Lucros }
\end{aligned}
$$

\section{1 .2 .3 . VALOR ATUAL DOS SUPER-LUCROS}

Seu mais antigo defensor foi Percy D. Leake, cuja forma de avaliacão levava em conta o decréscimo gradativo dos super-lucros e foi assim exemplificada por Carsberg:

Lucro Liquido .................... 23.500,

(-) Remuneraçào da Administracão ...... 500, Juros sobre Capital imobilizado em Ativos Tangiveis $8 \%$ a.a. de $100.000 \ldots 8.000, \frac{8.500}{15.000}$, 
Valor Atual dos Super-lucros decrescentes - periodo de 10 anos:

\begin{tabular}{cccc}
\hline Ano & Super - 1ucro & Fator de desconto & Valor-atua 1 \\
\hline 01 & 15.000, & 0,926 & 13.890 \\
02 & 13.500, & 0,857 & 11.570 \\
03 & 12.000, & 0,794 & 9.528 \\
04 & 10.500, & 0,735 & 7.718 \\
05 & 9.000, & 0,681 & 6.129 \\
06 & 7.500, & 0,630 & 4.725 \\
07 & 6.000, & 0,583 & 3.498 \\
08 & 4.500, & 0,540 & 2.430 \\
09 & 3.000, & 0,500 & 1.500 \\
10 & 1.500, & 0,463 & 695 \\
\hline
\end{tabular}

Valor do Goodwill ................6 61.683,

Sua representação algēbrica seria como segue:

$G=\sum_{t=1}^{k} \frac{\left(L L_{t}-R A-i A T\right)}{(1+r)^{t}}$

onde: $L L_{t} \ldots$... Lucro Lĩquido no momento $t$, que seria de crescente, acarretando super lucros decres centes

RA ..... Remuneração da Administração

i ..... Taxa de Juroṣ Aplicāvel ao Capital Imobilizado em Ativos Tangiveis

AT .......Ativos Tangiveis 
r.... Taxa de Desconto Atribuĩda aos Super-Lucros k..... Limite de Duracão dos Super-Lucros

3.1.2.4. DIFERENCA ENTRE O VALOR ATUAL DA EMPRESA E O VALOR DOS ATIVOS CONTABILIZADOS

a. FORMAS DE AVALIAÇÃO DO VALOR DE EMPRESA

Existem basicamente trēs formas de avaliação do va lor da empresa: Iucros Projetados ou Estimativa de Lucros Futuros, Fluxos Futuros Liquidos de Caixa Esperados e Preço de Mercado das Acões da Empresa. Todas podem ser tomadas co mo representativas do valor de continuidade da empresa, em termos de sua capacidade de geracão de lucros futuros, dentro de determinadas condições.

10. Lucros Projetados ou Estimativa de Lucros Futuros:

Devem ser descontados mediante a aplicacão de uma taxa adequada, geralmente considerada como tal a taxa cor respondente a empreendimento de igual risco, para obtenção do valor atual da empresa.

20 Fluxos Futuros Liquidos de Caixa Esperados:

Náo deixa de ser uma variante da anterior, mas enfatizando os fluxos de caixa relacionados com os resultados. Igualmente tais fluxos devem ser descontados mediante aplicação de taxa adequada para o cálculo do valor atual da empresa. 
30 Preco de Mercado das Acões da Empresa:

E, segundo seus defensores, uma aproximação vālida para o valor da empresa, quando suas acōes são pūblica e frequentemente transacionadas em Bolsa. Embora esses precos possam variar quase que diariamente, sua utilização seria justificada pelo fato de o preço de mercado de uma acáo representar a "opinião média" dos investidores a respeito da capacidade de lucro da empresa, sobretudo na inexistência de dados publicados sobre o seu futuro. J.E. Sands $(47)$ afir ma a respeito:

"The greater the likelihood that forecast wealth will not be realized, the less they are willing to pay for a chance for it. The greater the likelihood that forecast wealth will be realized, the more they are willing to pay for a chance for $i t$. And if they could be certain what the future wealth of a business would be, they would be willing to trade their present wealth for that future wealth at a rate $n f$ discount determined only by their preference for present over future wealth"

0 preco de uma ação, entretanto, tem o inconvenien te de, além do montante dos lucros projetados e do grau de risco envolvido na sua consecucão a influenciā-lo,estar sujeito a variacão decorrente de situacões conjunturais e me mo especulacões variadas.

(47) Apud George R. Catlett e Nornan 0.01son - "Accounting for Goodwill", Accounting Research Study no 10,AICPA. $1968, p .14$. 


\section{b. AVALIAÇÃO DOS ATIVOS CONTABILIZADOS}

19. Custo Histōrico

Atualmente, ē um mētodo amplamente criticado por ignorar as variacões da unidade de medida, bem como por não levar em consideracão alteracões nos precos especificos dos bens e servicos objetos da mensuração.

A mensuração dos demais ativos pelo valor do custo histōrico, i.ē, pelo seu valor na data de aquisicão, como manda o Principio do Custo como Base de Valor, teria toda a objetividade possível, porēm, seria a menos relevante, já que o goodwill resultante ficaria inflado não só pelos ativos não contabilizados, mas também pela grande diferenca en tre o valor econômico e o custo histörico dos ativos contabilizados, que numa economia inflacionāria torna-se ainda maior.

Do ponto de vista de sua magnitude o goodwill pode ria tornar-se até o ativo mais significativo, mas o seu valor seria desprovido de relevància, jā que parcela razoāvel dele seria decorrente de uma mensuracão incondizente com uma economia dināmica e preços não estáveis. Sua mensuração, entretanto, seria a mais fācil de ser realizada, bastando para tanto recorrer aos custos histōricos registrados pela contabilidade e dai apurar o goodwill pela diferenca com 0 valor atual da empresa como um todo.

Em resumo, o valor do goodwill por esse mëtodo seria a diferenca entre o valor atual da empresa como um todo 
e o seu patrimōnio líquido a custo histōrico.

20. Custo Histōrico Corrigido

A chamada correcáo integral ou correcao pelo siste ma do "price level"(48) procura eliminar os efeitos da varia ção na unidade de mensuração nos Demonstrativos Contábeis pela correcão conta a conta do Balanço Patrimonial e do Demonstrativo de Resultados, visando expressā-los em moeda de mesmo poder aquisitivo. O indice normalmente utilizado para a promocão dessa correção é o IGP (Indice Geral de Precos) por ser mais facilmente obtenivel, embora o mais represen tativo do efeito da inflação sobre a empresa fosse um indice especifico da empresa ou do seu ramo de atividade. E um mé todo que, embora aceito pela maioria, corrige apenas os efeitos da inflação na unidade de medida, mas deixa de considerar variacões ainda mais significativas nos precos espe cîficos dos bens e servicos a mensurar.

0 goodwill assim obtido, perde um pouco em objetividade, entretanto, ganha em relevāncia pois elimina do seu valor a parte referente ao efeito da inflacão, que deveria estar refletido nos valores dos contabilizados.

30 custo de reposição ou custo corrente

A "Security and Exchange Comission" através do Accounting Series Release" nọ 190 definiu o custo de repos cao como o mais baixo montante que teria de ser pago no cur

(48) No Brasil, a legislação brasileira preve um sistema de correçáo monetäria parcial do ativo permanente e patri. mónio liquido. 
so normal dos negócios para obter-se um novo ativo de capa cidade produtiva ou operacional equivalente.

E um dos mais usados como aproximação do valor eco nómico dos ativos, a avaliacão mais significativa, por não encontrar os mesmos obstáculos de mensuracão do valor econômico e ainda produzir valor de goodwill mais relevante que os métodos anteriores.

0 mētodo.se reveste de alquma objetividade, jä que os valores de mercado para bens novos nele transacio nados normalmente são mais fáceis de serem obtidos, embora alguma variacăo possa ocorrer de um fornecedor a outro - po der-se-ia nesse caso até utilizar uma média de cotacoos para a avaliacão. Já os bens usados, quando não houver mer cado de segunda não desenvolvido, não tem a mesma facilida de de avaliação.

Algebricamente a avaliação do goodwill, utilizando esse método poderia ser expressa como segue:

$$
\text { Goodwill }=\sum_{t=1}^{n} \frac{L L_{t}}{(1+j)^{t}}-P L_{c c}
$$

onde: $L_{t} \ldots . .$. Lucro lĩquido no período $t$

j ........ Taxa de desconto (custo de oportunida de oportunidade) corresnondente remune ração do empreendimento de inual risco $\mathrm{PL}_{c c} \ldots \ldots \ldots$ natrimōnio líquido em custos correntes. São reclamadas como vantagens desse método, entre outras:

a. em relaçào à questäo da renda, permite determinar quan- 
to a empresa pode distribuir aos seus proprietários sem enfraquecer a sua capacidade financeira de operar no mesmo nivel de atividade no futuro, aproximando-se nesse aspecto do conceito econōmico de renda;

b. quanto a questão da posicão financeira, possibilita à entidade o conhecimento de quanto lhe custarā repor os ativos gastos, os auạ são necessārios para manter o mesmo nivel de atividade no futuro;

c. proporciona um "matching" muito mais significativo entre receitas correntes e custos e despesas correntes, o que năo ocorre com o custo histōrico e o histōrico corrigido;

d. possibilita uma melhor avaliacão das decisões adminis trativas, na medida em que separa os resultados decor rentes das operacões dos ganhos de manutenção de ativos;

e. constitui-se em base melhor para a estimativa das cond cöes operacionais futuras, possibilitando ainda a compa rabilidade entre as entidades.

Entretanto, além de violar os princípios da real 1 zação e do custo como base de valor, seus criticos apontam as seguintes deficiências ao método:

1. a mensuração não é suficientemente objetiva e verificável, pois o mercado não é perfeito e as variacões são grandes, alēm do que existem os problemas das mudancas tecnológicas, dos ativos para fins especiais, dos não reprodutiveis e dos complexos, que dificultam a sua apu ração; 
2. a distribuicão de resultados entre atividades operacionais e de manutencão de ativos é artificial;

3. repousa em esquemas de alocação arbitrários para os at $\underline{i}$ vos depreciáveis:

4. não apresenta posicões financeiras em termos de valores de realização e de liquidação, que são mais relevantes;

5. nao é uma medica acurada dos custos de oportunidade;

6. o que deve ser reposto? o ativo no estado em que se encontra ou o seu potencial de servicos?

Apesar dessas criticas, o Custo de Reposicão, especialmente a sua versão mais completa, o Custo de Reposicão A.justado ou Custo Corrente Corrigido, que permite ainda apurar o efeito da inflação, teve a sua relevāncia reconhecida pela pröpria SEC ("Security and Exchange Comission".), que exigiu, para as grandes empresas americanas, 0 "disclosure" dos Custos Correntes de Reposicão estimados dos inventärios e de capacidade produtiva, no final de cada exercício fiscal, bem como do montante aproximado dos custos de venda e depreciacão, com base nos custos de reposicão, para os dois exercicios fiscais mais recentes.

0 goodwill resultante dessa forma de avaliação de ativos seria a diferenca entre o valor atual da empresa co mo um todo e o patrimōnio liquido a custos correntes ou de reposicäo./

40. Valor Lĩquido de Realizacào

0 Valor Líquido Realizāvel de um ativo é definido como o montante māximo que pode ser realizado na venda des 
se ativo dentro de um curto período de tempo - não tão cur to para caracterizar uma situacão de venda forcada, porém, não suficientemente longo para permitir a liquidação do ativo fixo pelo uso. 0 montante liquido em questão corresponderia ao preco de venda menos os custos de realizacão, incluindo impostos, descontado até o ponto de mensuracăo.

As vantagens relativas à utilizacão desse mētodo seriam, de acordo com os seus defensores:

a. o lucro poderá ser determinado a qualquer tempo pelo cálculo da diferenca entre os ativos lîquidos no início e final de cada periodo, ajustado pelos aumentos de capital com novos recursos e pelos dividendos distribui dos;

b. em termos de decisões administrativas, a continua atualizacão dos precos provē a administracão com a informacão necessāria para a tomada de dicisões de vender ou manter ativos e ainda de extinguir ou refinanciar exigi bilidades;

c. serā mais apropriado aos usuärios que gostariam de conhecer o montante que poderia ser realizado pela empre-

- sa e a eles distribuído pela venda de ativos;

d. seu uso poderā motivar a administracão a fazer a escoIha mais desejāvel entre as alternativas disponiveis;

e. o lucro líquido, o numerador no cálculo do retorno sobre investimentos, poderā ser computado utilizando-se as mensuracões dos valores lïquidos de realizacão dos ativos; 
Seus opositores, no entanto, alinham as seguintes crîticas ao mētodo:

1. antecipa os lucros ou prejuizos, violando não só os principios do custo como base de valor e da realizacão, bem como o critērio bàsico do "matching";

2. são impraticáveis, pois nem sempre são obtenịveis, como no caso de produção em andamento e de ativos especializados, os quais não tem mercado para venda, impossibili tando a avaliação do seu valor de realização;

3. avaliando os ativos pelos valores liquidos de realizacáo, a Contabilidade teria problemas se os precos comecassem a cair;

4. seu uso, è por necessidade, uma abordagem de curto prazo e, uma diferenca positiva entre o valor liquido de realização e o custo, na data do balanço, não indica na da acerca do eventual resultado que se obteria na venda do ativo em questão.

- Valor Liquido de Realização, sem dūvida, viola um maior nümero de princīpios e convencões contābeis gera mente aceitos que os métodos anteriormente abordados, porém não é menos objetivo que o método do Custo de Reposi ção. Produz, por outro lado, valores mais relevantes para - Goodwill assim apurado que os mét.odos do custo histōrico e do histōrico corrigido.

0 prof. Iudicibus ${ }^{(49)}$ exemplifica a apuracão do $\therefore$ goodwill por esse método utilizando a förmula:

(49) Op.cit.,pg. $196 / 197$. 


$$
\text { Goodwil1 }=\sum_{i=1}^{n} \frac{L_{i}-r P L_{i-1}}{(1+j)^{i}}
$$

onde:

$$
\begin{aligned}
& \text { i } \ldots \ldots \ldots \text { é o horizonte de projecão dos resulta- } \\
& L_{i} \quad \ldots \ldots \text { lucro projetado para o período } \underline{i} \text {; } \\
& \text { r } \quad \ldots \ldots t \text { taxa de retorno de investimento de ris } \\
& \text { co zero; a taxa de custo de oportunida } \\
& \text { de aplicāvel à um } \mathrm{PL}_{j} \text {, por apresentar } \\
& \text { - recebimento do } \mathrm{PL}_{i} \text { um risco nulo (es } \\
& \text { tá avaliado a valor de realização); } \\
& \mathrm{PL}_{\mathrm{j}} \text {....... patrimōnio líquido a valores de reali- } \\
& \text { zação (tangíveis e intangíveis), no mo- } \\
& \text { mento } \underline{i} \text {; } \\
& \text { j } \ldots \ldots \text { taxa desejada de retorno, que deve ser } \\
& \text { superior a taxa } \underline{r} \text {, em funcão do prēmio } \\
& \text { atribuivel ao risco maior na obtenção } \\
& \text { de } L_{i} \text {. }
\end{aligned}
$$

Sendo indefinido o horizonte de projeção, mas podendo-se projetar um lucro médio e um patrimōnio líquido médio a valores de realizacão, o prof. Iudicibus chega a seguinte fórmula simplificada para a apuracão do goodwill:

$$
\text { Goodwill }=\frac{L-P L r}{j}
$$

50. Valor Econömico ou de Uso dos Ativos 
0 prof. Eliseu adotou como definicão de Valor Eco nômico de um ativo o valor atual mäximo dos resultados eco nómicos futuros esperados, utilizando para o seu cálculo a taxa de descontos correspondente ao custo de oportunidade de igual risco.

o resultado econōmico atribuível a um ativo em um exercicio social corresponderia a soma entre as receitas produzidas com a sua utilização (exemplo: 5.000 unidades $x$ preço unitário de venda do produto) e o valor venal desse ativo no final do mesmo exercício. Sua expressão algébrica poderia ser representada como segue:

$$
A_{i}=\frac{v_{t}}{(1+j)^{t}}+\sum_{t=1}^{n} \frac{R_{t}}{(1+j)^{t}}
$$

onde:

$$
\begin{aligned}
& A_{i} \ldots . . \text { Valor económico de um ativo } \\
& v_{t} \ldots . . \text { valor venal do ativo no final de cada } \\
& \text { perĩodo } t \\
& \text { j ..... Taxa de desconto (custo de oportunida- } \\
& \text { de) correspondente à remuneração de em- } \\
& \text { preendimento de igual risco } \\
& \text { m ..... Período em que a soma de } v_{t} \text { e } \Sigma R_{t} \text {, } \\
& \text { descontados, representa o valor econō- } \\
& \text { mico máximo } \\
& R_{t} \text {..... Resultado económico produzido pelo at } \\
& \text { vo no periodo } t \text {. }
\end{aligned}
$$

Trata-se da avaliacão ideal de ativos, entretanto, 
encontra sērios problemas na sua implementaçāo, jä que,embora seja possível a apuração do valor económico do ativo total, a sua necessāria individualizacão em termos de ativos especificos ē praticamente impossivel de concretizacäo.

Além disso, ao se avaliar os ativos pelo seu valor económico māximo, eles trarão embutidos o valor do goodwill da empresa que, atē prova em contrārio, constitui se em um ativo distinto e como tal merece um registro em separado.

Por outro lado, sendo a producão de receitas o re sultado da combinacão de vārios ativos diferentes, como individualizar a contribuição de cada um? Uma solucão possĩvel seria o agrupamento de ativos - por exemplo: planta ou capacidade produtiva - e avaliā-lo como um único ativo para efeito de avaliação do seu valor económico, porém isso traria consigo o problema da apuracão do valor venal dos ativos individuais componentes do grupo.

Um dos grandes entraves a sua aceitação, além das jā mencionadas dificuldades de aplicacão, é o grau de subjetividade na sua mensuracão, muito maior que nos métodos anteriores, e, naturalmente a não obediēncia a alguns dos mais importantes principios e convencões contābeis geral mente aceitos.

\subsubsection{MÉTODO DE APURAÇÃO PELO VALOR MARGINAL}

E o metodo apresentado por Mattessich ${ }^{(50)}$, para quem o valor da empresa (VE) equivaleria a soma dos valores de 
utilidade dos ativos fixos - não leva em consideraça os outros ativos - e o goodwill corresponderia a diferenca en tre aquele valor e o valor monetärio (VM) desses ativos fí xos.

Embora tenha afirmado não ser tão difícil a estimaça da função $V E=f(V M)$, que teria um tracado semelhan te ao da curva de custo marginal, não realizou a sua especificacão(51), presumindo talvez a variabilidade de sua conformaçäo de acordo com a empresa; em vez disso, utili zou para seus exemplos uma forma linearizada.

Graficamente, assim seria representada:

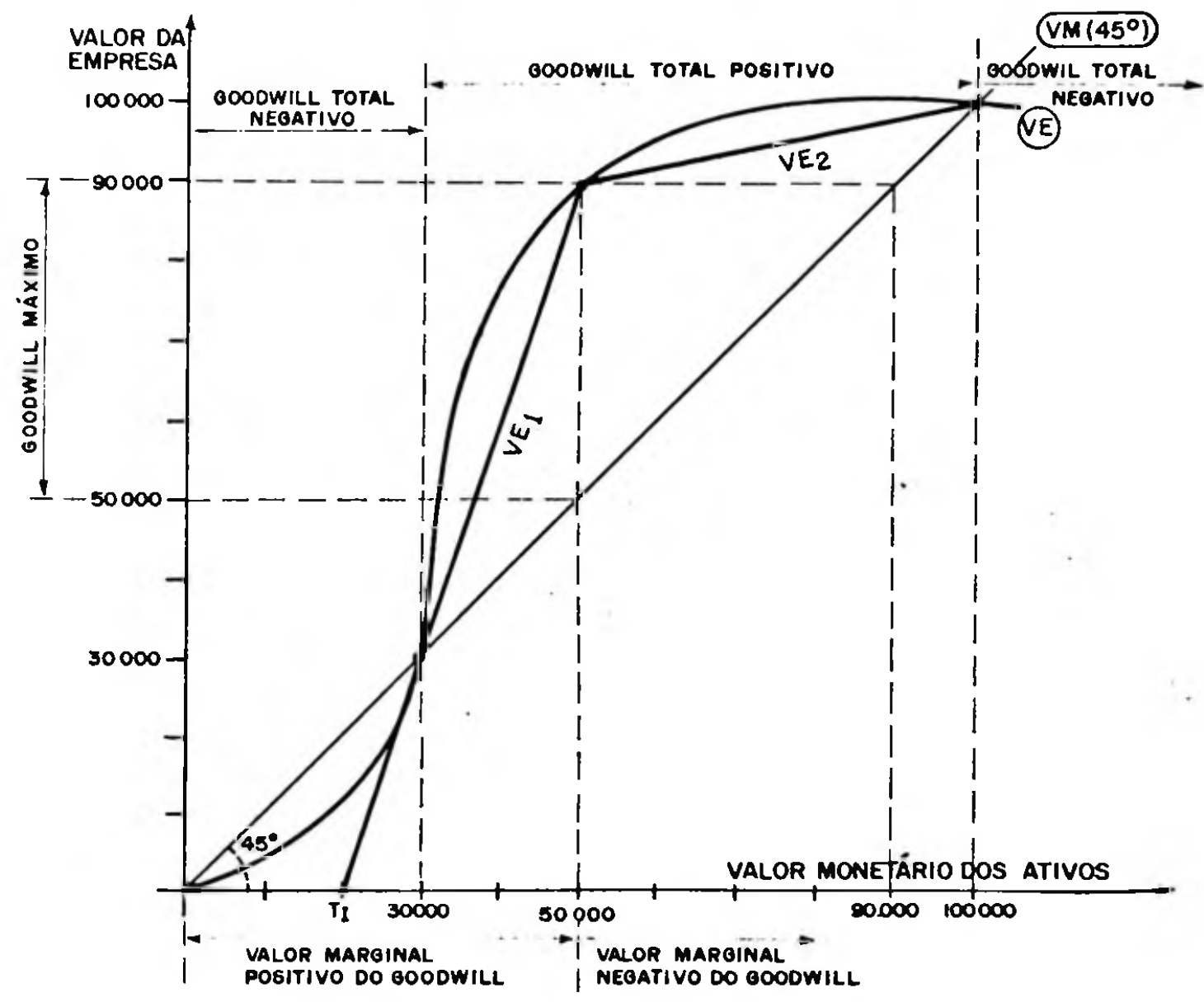

(50) Op. cit. p. 227.

(51) Apesar da não especificação, deduz-se que $V E=f(V M) \quad \ldots$ 
A reta VM de $45^{\circ}$ tem apenas a função de comparação, enquanto as retas $V E_{1}$ e $V E_{2}$, decorrentes da lineariza ção, tem os coeficientes de inclinacão $c_{1}$ e $c_{2}$, respectiva mente. Enquanto na reta $V E_{1}$ o goodwill seria apurado pela förmula $G=V M\left(c_{1}-1\right)$, na reta $V E_{2}$ o seria pela förmula $G=V M\left(1-c_{2}\right)$.

Para contabilizacão propõe a utilização das contas Goodwill (ativo) e Reserva de Goodwill (patrimōnio liquido), admitindo a existēncia de goodwill negativo.

Atē o ponto $T_{I}$, limiar do investimento ("Threshold Investment), todo o valor de aquisicão de ativos fixos seria simplesmente baixada a débito de Reserva de Goodwill e a crēdito de Goodwill (negativo).

Mattessich defende sua abordagem como capaz de contínua revisão do valor do goodwill, facilitando tambēm ... seria una função do tipo:

$$
f(x)=a_{0}+a_{1} x+a_{2} x^{2}+a_{3} x^{3}+\ldots+a_{n} x^{n}=\sum_{i=0}^{n} a_{i} x^{i}
$$

Portanto, o Goodwill (G) seria representado pela expres são a seguir:

$$
G=f(x)-b x=\left(\sum_{i=0}^{n} a_{i} x^{i}\right)-b_{x}
$$

é, considerando que, no ponto de $f(x)$ onde o goodwill é máximo, a tangente a essa curva é paralela a bx, e que $d[f(x)-g(x)]=d f(x)-d g(x)$, teriamos:

$$
\begin{aligned}
& d\left(\sum_{i=0}^{n} a_{i} x^{i}\right)=d \text { bx donde } \\
& \underset{i=1}{n-1} i a_{i} x^{i-1}=b
\end{aligned}
$$

cuja solução resultaria no goodwill máximo da empresa. 
a determinação do valor da empresa a qualquer momento. En tretanto, alēm de não considerar os demais ativos na apura cão do goodwill, não deixa de ser um dos métodos mais subjetivos.

\subsubsection{DIFICULDADES RELATIVAS A MENSURAÇ̃̃o}

\subsubsection{LUCROS FUTUROS PROJETADOS}

Qualquer que seja o método a ser utilizado para a apuração do valor da empresa e, consequentemente, do goodwill, a estimativa dos seus lucros futuros, nos quais estará interessado o usuārio, serā uma das questōes problemāticas com que se defrontará.

Como se comportarão os fatores que influenciaram o desempenho da empresa no passado? Se mudancas são espera das, em que grau afetaräo os resultados futuros da empresa?

Todos esses aspectos devem ser considerados na projeção dos lucros futuros para que seja reduzido o grau de incerteza do futuro ou, pelo menos, seja determinada uma amplitude de variacão das estimativas efetuadas.

NECESSIDADE DE AJUSTAMENTO DO LUCRO. Na anālise do comportamento passado dos lucros da empresa, atencão deve ser dada na composicão desses lucros, pois podem decorrer de at vidades não operacionais ou mesmo de manipulações, especialmente no ültimo ano. Assim, os lucros podem ser resultan tes de vendas de ativos, antecipacão no reconhecimento de receitas elou postergacão no de despesas. Na sua ocorrēn - 
cia, os lucras devem ser ajustados com a inclusão ou exclu são dos efeitos desses fatos, em cada exercício social, pa ra só depois elaborar-se as estimativas dos lucros futuros do negōcio.

TENDENCIA DO COMPORTAMENTO DOS LUCROS. Comportamento estāvel, grande variabilidade e tendēncia firmemente crescente ou decrescente podem estar escondidas em um comportamento médio igual. Suponha-se as seguintes empresas e lucrós $1 \vec{i}-$ quidos:

QUADRO 3.1 .

\begin{tabular}{rrrrr}
\hline Ano & Empresa A & Empresa $B$ & Empresa $C$ & Empresa D \\
\hline $19 \times 1$ & 31.000 & 45.000 & 18.000 & 40.000 \\
$19 \times 2$ & 29.000 & $(15.000)$ & 24.000 & 35.000 \\
$19 \times 3$ & 30.000 & 90.000 & 30.000 & 30.000 \\
$19 \times 4$ & 29.500 & $(20.000)$ & 36.000 & 25.000 \\
$19 \times 5$ & 30.500 & 50.000 & 42.000 & 20.000 \\
Total & 150.000 & 150.000 & 150.000 & 150.000 \\
Média & 30.000 & 30.000 & 30.000 & 30.000 \\
\hline
\end{tabular}

Embora os lucros médios do perỉodo $19 \times 1$ a $19 \times 5$ se jam exatamente iquais, as projeções de lucro deverão ser totalmente distintas se se considerar o seu comportamento pregresso, melhor visualizāvel no grāfico a seguir.

Admitindo-se a desnecessidade de ajustamentos,excetuando-se a empresa $B$, cujo comportamento irregular do lucro, näo permite qualquer estimativa confiāvel, as demais empresas poderiam ter os seus lucros futuros estima - 
Lucro

GRÁFICO 3.1.

Lỉquido

$(\mathrm{em} 1.000)$,

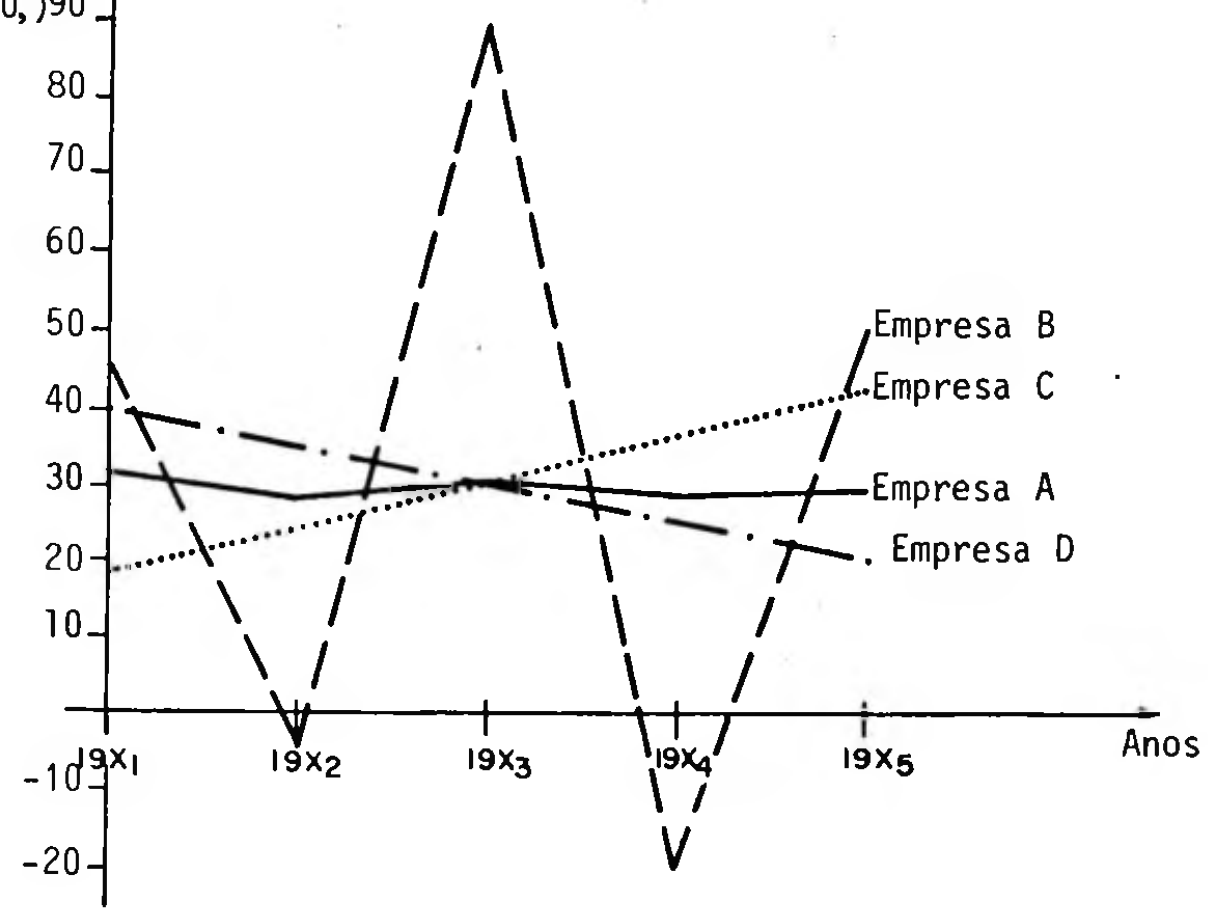

dos com razóavel segurança, porém em valores diferentes, em funcão das tendéncias verificadas nos comportamentos dos seus lucros passados. Isso naturalmente se os fatores que agiram no passado não se modificarem significativamente no futuro. E de se esperar, por outro lado, que se os lucros forem extraordinariamente arandes em determinado ramo de atividade, estes não se repitam por muito tempo, jã que isso atrairia outras empresas até o atingimento de uma situacão de equilibrio em termos de lucratividade na economia.

A projecão de lucros torna-se uma tarefa quase impossivel quando relativas a empresas recém criadas, portanto, sem comportamento de lucros passados para fundamentar quaisquer estimativas de lucros futuros. 


\subsubsection{TAXa de descontos para calculo do valor atual}

A taxa ideal mais recomendada para o desconto é a taxa de remuneracão de empreendimento de igual risco. Daí surgem questöes de difícil solução satisfatōria:

10. 0 que ē um empreendimento de igual risco? uma empresa do mesmo ramo de atividade e com igual estrutura organizacional e financeira?

E de se deduzir que, para dois empreendimentos terem igual risco, hā necessidade de que as empresas sejam absolutamente iguais, uma situacão puramente teórica, pois, na prätica, no máximo poderiam ser semelhantes.

20. Considerando além disso, que essa taxa pode variar no tempo, como contornar ou amenizar seus efeitos no cálculo do valor atual?

Não obstante ser a taxa ideal, a sua determinação na prātica acaba sofrendo distorcões, tornando aceitável a utilizacão de taxas alternativas mais facilmente obteniveis, como a taxa média de remuneracão de empresas com es trutura econōmico-financeira similar, no mesmo ramo de at vidade ou na economia como um todo. Mesmo considerando a tendência de longo prazo ao equilíbrio, existirão sempre pequenas diferencas atribuỉveis as peculiaridades ineren tes a cada ramo de atividade, assim, seria mais justificável o uso da taxa média do ramo de atividade a que pertence a empresa. 


\subsubsection{IDENT IFICAÇÃO E MENSURAÇAO DOS OUTROS ATIVOS}

Tratando-se o goodwill do resultado de uma mensura cáo dependente, qual seja dos outros ativos utilizados pela empresa, seria fundamental a identificacão e mensuracão do valor económico ou de uso de cada um deles. E, entretanto, quase impossível concretizar-se tal mensuração na prātica, pois implicaria em calcular a contribuicão individual de to dos esses ativos nos resultados da empresa - cada ativo seria avaliado pelo seu valor de uso, i.e, pelo que pudesse produzir para a empresa e não de acordo com o seu custo ou valor realizāvel.

Dada a dificuldade apontada, tem-se utilizado frequentemente, como alternativas para mensuracão, tanto o cus to histōrico como o custo de reposicão, resultando valores diferentes para o qoodwill conforme o método utilizado.

A existência de capacidade ociosa introduz outra complicacão pois, teoricamente, para a empresa objeto da venda năo teria valor econōmico ou de uso, enquanto o mesmo poderia não ocorrer com a adquirente. Uma solução poderia ser a sua avaliação pelo valor líquido de realização,se não desejāvel pela adquirente e possível a sua separacão e venda.

\subsubsection{OBJETIVIDADE X RELEVÂNCIA}

A anālise comparativa dos mētodos utilizados na avaliação dos ativos, os quais tem influência direta no valor do goodwill apurado, deve ser efetuada à luz dos crité- 
rios de objetividade e relevância.

0 método de mensuracão ideal seria aquele que produzisse resultados de relevāncia māxima, com um māximo de objetividade. Entre dois métodos que produzissem mensurações de igual relevancia, o melhor seria aquele que fosse mais objetivo.

A prātica, entretanto, não tem oferecido essa opcäo para a escolha do método, assim, Penman (52) analisando os métodos do custo histōrico, custo de reposicăo,valor de realização e valor atual, concluiu ser o primeiro o mais objetivo, porém o menos relevante, e, o ūitimo o mais relevante, mas o menos objetivo, rejeitando dessa forma todos os métodos analisados.

Esse dilema surgirā sempre que se insistir em ponderar igualmente a objetividade e relevāncia, na avaliaça de um método de mensuracão, pois, em realidade, apenas o custo histōrico é realmente objetivo, razão porque muitos o defendem como forma de resguardar a Contabilidade de quaisquer riscos de subjetividade, enfatizando a seguranca da in formação, embora em detrimento completo da sua relevãncia. Esses defensores ferrenhos julgam ser a atribuicão da conta bilidade concernente aos fatos passados, cabendo a cada usuārio, com base nesses dados, conjecturar sobre as possíveis situações futuras da entidade.

0 desenvolvimento e utilizacão crescente de mode los matemáticos e estatisticos em todos os campos do conhecimento humano, inclusive nas Ciências Médicas e Psicolónicas, (52) Op. cit. pg. 82 . 
näo justificam essa postura excessivamente defensiva

Contabilidade, pois isso pode acarretar-lhe um atraso rela tivo de consequências futuras graves.

Se a relevāncia da informação é essencial para o usuārio, por que oferecer-lhe apenas a objetividade de men suracão? A seguranca, na realidade, visa mais resguardar a entidade que ao usuārio, portanto, faz-se necessária uma mudanca na ênfase dada, privilegiando mais a relevāncia das informaçoes que a objetividade, com utilizacão, sempre que possivel, de técnicas estatisticas.

\subsubsection{CONSEQUENCIAS DAS DIFICULDADES DE MENSURAČ̃O}

A incerteza inerente aos resultados da mensuracão, o conservadorismo contābil e a própria natureza do goodwill são talvez os principais responsāveis pela tendéncia a tra tamentos atē arbitrários para eliminar o goodwill adquirido dos registros cantābeis e o não reconhecimento do goodwill não adquirido.

Esses procedimentos acarretam a irrealidade dos demonstrativos contábeis, que acabam muitas vezes esconden do mais do que demonstram.

3.1.4. GOODWILL SINERGISTICO: UM RESULTADO DA MENSURACÃO IDEAL

3.1.4.1. OMNICIENCIA DO MENSURADOR

Se o responsāvel pela mensuração fosse omnicien 
te ${ }^{(53)}$, i.e. , ciente de tudo, todos os problemas estariam re solvidos e a identificaçào e mensuração do valor econōmico (ou de uso) individual de todos os ativos da empresa,inclusive daqueles atualmente não contabilizados, não constituiria nenhum obstáculo. Também a taxa de remuneracăo de igual risco, aplicável na apuracăo do valor atual dos lucros futu ros, seria conhecida pelo mensurador, de forma que o goodwill sinergístico desejado fluiria da diferenca entre o valor atual apurado da empresa e a soma do valor económico individual de todos os ativos.

0 goodwill sinergístico, assim apurado, poderia melhor representar um valor atribuível aos recursos humanos, que a capitalizacão de toda a diferença entre os super-lucros e os lucros normais sobre os ativos possuidos, como o queria Hermanson (54), ao propor um modelo de avaliacão do valor dos recursos humanos - seu modelo só levaria ao goodwill sinergístico, se todos os ativos fossem idenficados e mensurados, e a aplicacão de sua taxa de retorno normal resultasse no valor económico daqueles ativos.

Por se tratar do ūnico fator de desempenho de uma empresa, com capacidade de atuar sobre os demais fatores de lucro e de decidir sobre a sua melhor combinacão, os recursos humanos seriam o grande responsāvel pelo goodwill siner gistico.

(53) Termo utilizado por Stephen H. Penman op.cit.,pg.80.

(54) Brummet, R. Lee - "Human Resource Accounting" in Davidson, Sidney \& Weil,. Roman L., "Handbook of modern Accounting", McGraw-Hill Book Co., 1977 p. 37-12. 


\subsubsection{2, LIMITACÕES A MENSURAÇÃ IDEAL}

Em primeiro lugar, a omniciēncia é uma utopia e a identificação e mensuração do valor econômico individual de cada atividade nào é possível, pelo menos dentro dos padroes exigidos pelos princípios e convencões contábeis geralmente aceitos. A agravar essa dificuldade prätica, mui tos desses fatores importantes na consecucão dos lucros de uma empresa sequer são contabilizados, em razão da impossibilidade de caracterização como ativo, no sentido convencio nal - caso específico dos recursos humanos - e da quase impossibilidade de uma mensuração objetiva. Dessa forma,o va lor atribuivel a esses fatores acabam constituindo-se em parte integrande do goodwill convencional.

Por outro lado, a interferéncia de situações conjunturais, favorāveis ou desfavoráveis, nos resultados de uma empresa, tornam mais dificil o isolamento do efeito sinergistico propriamente dito.

\section{$3,1,4,3$, ALTERNATIVAS PARA MENSURACÃO APROXIMADA}

$\mathrm{Na}$ impossibilidade prātica da apuração do goodwill sinergístico ideal, pode-se lançar mão de métodos alternati vos que produzirão valores de goodwill, ainda inflados pela participação de outros fatores, que, gradativamente, na medida em que a Contabilidade os contemplar em seus regis tros, terão individualizadas e mensuradas as suas contribui cōes. Mas, sem dūvida, o componente mais importante desse 
goodwill serā aquele decorrente da sinergia organizacional, o.goodwill que continuarā existindo mesmo apōs a identificação e mensuração de todos os ativos, sem excecão. Assim, mesmo estando ainda longe da apuracäo adequada do goodwill sinergistico, o presente trabalho defende uma mudanca de enfoque, direcionando-o para o goodwill sinergistico,ao in ves do goodwill convencional que, na medida do avanco da Contabilidade, tenderá para aquele.

A aproximação ao goodwill sinergỉstico poderia ser conseguida pela contabilização de recursos humanos e ativa cão de despesas de pesquisa e desenvolvimento e propaganda e publicidade.

\section{a. CONTABILIZAÇÃO DE RECURSOS HUMANOS}

Os recursos humanos, reconhecidamente o fator mais importante na obtenção dos lucros empresariais, ainda não sao objeto dos registros contābeis - as discussões em torno do assunto levam a crer que, num futuro não muito distante, sua contabilização seja aceita- dificultando a avaliação da capacidade de lucro da empresa, especialmente para os usuários externos.

Segundo a professora Eunice L. Kwasnicka (55), a con tabilizacăo dos recursos humanos teria grande impacto na

(55) Kwasnicka, Enice L. - "O impacto da Utilizaça de um sistema de Contabilização de recursos humanos na organiza cão" - tesc de doutoramento apresentada na FEA-USP e m $1981, \mathrm{pg} .7 / 8$. 
administracão pois "muitos administradores advogam a nivel teörico que:

a. necessitam de informacões mais completas sobre o valor real do pessoal que está deixando a organizaçao;

b. necessitam estimar a taxa de investimento em recursos humanos sobre o ativo total como um indicador de gera cä́o de lucros futuros;

c. é necessärio avaliar alternativas que.permitam decidir sobre o orcamento de capital, principalmente em casos onde deve-se optar entre investimentos em recursos huma nos e outros investimentos;

d. as taxas de retorno sobre os investimentos poderão ser interpretadas de forma mais inteligente se o valor do ativo humano for estimado e incluido na taxa base de re ferência;

e. hà necessidade de poder estimar o valor do treinamento e dos programas de desenvolvimento em uma sistemātica de estimacão do esperado retorno sobre o investimento em recursos humanos;

f. hã necessidade de saber se o custo de reposicão de sua mão-de-obra, de forma que a aquisicão dessa mão-de-obra se torna um seguimento do orcamento de capital;

g. a composicão do inventārio dos recursos humanos permiti rá elaborar melhor o planejamento de mão-de-obra".

A näo contabilização dos recursos humanos não per mite ao administrador uma avaliacão das decisões concernen tes a esse importante fator, levando-o a otimizar suas de- 
cisões em relacão aos recursos contabilizados. Não é sem razäo que, quando custos precisam ser cortados, a decisăo de dispensa de recursos humanos é a mais comum, embora pro vavelmente a mais onerosa, em funcão de todos os gastos efe tuados na sua contratacão e treinamento. 0 administrador, por outro lado, tende a enfatizar o desempenho daqueles a $\underline{s}$ pectos que serão objeto de avaliação.

Embora preocupação antiga da Administração, a Con tabilidade só começou a discutir a sua contabilizacão ou não a partir da década de sessenta, sendo particularmente importantes as contribuicões de Rensis Likert (56) Hekimian e Jones ${ }^{(57)}$, Brummet, Pyle e Flamholtz ${ }^{(58)}$ e Hermanson(59).

E indispensāvel ainda a menção das experiēncias pioneiras na contabilizacão de recursos humanos realizadas por "Touche Ross \& Co "(Canadā), em 1971, e por "R.G. Barry Corporation" (EUA), em 1973, que sentiram a relevāncia de $\underline{s}$ sa informacăo na tomada de decisões pelos usuārios exter nos. Entretanto, exceto para clubes profissionais de espor tes, hä ainda grandes resistēncias a sua contabilizacão.

A não contabilização de recursos humanos, segundo Brummet $(60)$ acarretaria:

\section{"...The failure of organization to capitalize}

(56) Likert, Rensis - "The Human Organization, its management and value" McGraw-Hil1, Book Co. NY, 1967.

(57) Hekimian, J.S. e Curtis, H.J. - "Put people on your Balance" - Harvard Business Review, jan/fev 1967.

(58) Brummet, L., Pylc, W. C.. e Flamholtz, E. - "Accounting for lluman Resources" - Michigan Business Review, march/ 1.968 .

(59) Hermanson, R.H. - "Human Resource Accounting" - The Accounting Review, jan/1973.

(60) op. cit. pg. 37-21. 
certain investments in human resources causes profit to be significantly understated in periods of rapid human resource building and significantly overstated in periods of human resource deterioration. In this way managers and indeed stockholders and the public are misled and perhaps caused to make counterproductive decisions. The danger in this area are particulary great for segment performance reports using profit center accounting. A manager may use a management style which results measured by conventional accounting in the short run as highly contributive to profit even though employee attitudes are deteriorating and antagonisms are growing. The manager's actions may be detrimental to the oraanization even though profits appear very satisfactory. A fully implemented human resource accounting system would bring the situation to a reckoning so as to prevent the rewarding of poor performance and make possible the rewarding of good, more complete performance..."

Brummet propõe ainda a adaptacão do indice de lucratividade sobre o ativo para

$$
\begin{aligned}
& \text { indice }=\frac{\text { lucro convencional } \pm \text { variação recursos humanos }}{\text { ativos convencionais }+ \text { ativos humanos }} \\
& \text { Apesar da importância extensamente ressaltada, exis }
\end{aligned}
$$


tem muitos problemas para a sua implementacão, tanto do pon to de vista conceitual como técnico. Conceitualmente, os re cursos humanos encontram as seguintes objecóes principais a sua contabilização:

- de ordem cultural e aqueles decorrentes de tabus, jā que a seres humanos seráo atribuídos valores;

- o ativo contábil tem por base conceito legal de proprieda de, ao qual não se enquadram os recursos humanos.

Alem disso, tecnicamente seria muito dificil a ava liação do valor de recursos humanos - exceto se se considerasse como sendo o seu valor o custo histórico dos gastos com contratacão e treinamento - e a atribuicão de vida ūtil, sobretudo se a rotatividade for elevada. Na avaliaça do va lor de recursos humanos é certamente imprescindivel a con tribuicão de profissionais de psicologia Industrial e Administradores de pessoal. E razoável esperar-se, por outro lado, que numa economia mais desenvolvida e estabilizada, on de as oportunidades e as remuneraçōes não sejam tão diferen tes, a mobilidade da mão-de-obra se torne bastante reduzida ${ }^{(61)}$.

Removidos esses obstáculos ou adaptada a teoria con tābil à nova realidade, rapidamente se difundirā a contabi1 ização dos recursos humanos, produzindo informacões da mais alta relevāncia para os usuärios - o contexto atual ainda apresenta resistências incontornāveis a esse procedimento, como o concluiu a própria professora Kwasnicka.

(61) No Japão, onde a rotatividade de mão-de-obra é uma das malis baixas do mundo, as razöes culturais descimponham papel importante. 
b. ATIVACÃO DE DESPESAS COM PESOUISA E DESENVOLVIMENTO $E$ PROPAGANDA E PUBLICIDADE

Em verdade, o lançamento desses gastos como despesas do exercício em que cäo realizados contraria frontalmen te o critério do "matching", jā que a maioria reconhece que seus benefícios irão fluir no futuro, tal como ocorre com muitos ativos possuidos. Entretanto, face a dificuldade de mensurar os seus efeitos e a duração dos mesmos, o conserva dorismo impõe o seu imediato reconhecimento como despesas.

PESQUISA E DESENVOLVIMENTO, Demonstrando a importāncia assu mida por esses gastos, sobretudo nas industrias de vanguarda, Welsch, Zlatkovich e Harrison (62) apresentam o quadro abaixo, extraido do "Business Week":

OUADRO 3.2 .

\begin{tabular}{|c|c|c|c|c|c|}
\hline \multirow{2}{*}{ Indūstria } & \multicolumn{2}{|c|}{ Milhões de US\$ } & \multirow{2}{*}{$\begin{array}{c}P \& D \\
\% \\
\text { vendas }\end{array}$} & \multirow{2}{*}{$\begin{array}{c}P \& D \\
\& \\
\text { Iucros }\end{array}$} & \multirow{2}{*}{$\begin{array}{c}P \& D \\
\text { por } \\
\text { empregado }\end{array}$} \\
\hline & $\begin{array}{l}\text { vendas da } \\
\text { industria }\end{array}$ & $\begin{array}{r}\text { gastos em } \\
\text { P \& D }\end{array}$ & & & \\
\hline Aeroespacial & 25.589 & 884,5 & 3,5 & 131,3 & 1.668 \\
\hline Automobilistica & 116.799 & $2.941,7$ & 2,5 & 57,8 & 1.501 \\
\hline Química & 56.221 & $1.438,8$ & 2.6 & 39,7 & 1.720 \\
\hline $\begin{array}{l}\text { Alimentos e Be } \\
\text { bidas }\end{array}$ & 59.888 & 301,9 & 0,5 & 12,4 & 337 \\
\hline $\begin{array}{l}\text { Equipamentos de } \\
\text { Escritōrio e } \\
\text { Computadores }\end{array}$ & 36.839 & $1.978,1$ & 5,4 & 55,8 & 2.347 \\
\hline Total Industr. & 867.174 & $16.224,7$ & 1,9 & 33,9 & 1.149 \\
\hline
\end{tabular}

(62) Op. cit. pg. 524. 
0 quadro mostra a aplicação média de um terço dos lucros das indústrias em pesquisa e desenvolvimento, propor cão essa que sobe para mais da metade nas indūstrias de equi pamentos de escritório e computacao, de alta tecnologia.

Nos EUA, até 1974 , os procedimentos contābeis adotados quanto a esses gastos eram os mais variados, pois per mitia-se:

$i$ lancar todos os gastos com $P$ \& $D$ quando incorridos, in cluindo propriedade, planta e equipamentos adquiridos para essa finalidade, mantendo-se apenas seus registros simbölicos ao valor de $\$ 1$ cada;

ii. capitalizar os ativos fixos adquiridos e lancar os outros gastos como despesas na medida da sua incorréncia;

iii. capitalizar os esforcos bem sucedidos, que tivessem re sultado em descobertas, bem como os ativos fixos adqui ridos e, finalmente

iv . capitalizar todos os gastos com $P \& D$, incluindo os custos operacionais da divisão de pesquisa e amortizálos nos periodos futuros.proporcionalmente a venda ou producão dos produtos inventados ou recursos descobertos.

Essa situação foi modificada com 0 advento do "Statement" nọ 2 do FASB, de outubro de 1974, que estabeleceu como regra geral o lancamento dos gastos com pesquisa e desenvolvimento como despesas do perỉodo em que fossem in corridos, exceto: 
1. gastos com $P \& D$ realizados por conta de terceiros sob contrato, onde o reembolso é esperado;

2. gastos com $P$ \& D realizados por indústrias extrativas;

3. gastos com $P$ \& $D$ realizados por indústria requladas pe10 governo;

4. materiais, equipamentos e intangiveis adquiridos para P \& D com possibilidade de usos alternativos no futuro.

0 tratamento definido, objetivou mais a padroniza cáo dos procedimentos das empresas, ao mesmo tempo que for taleceu a validade do conservadorismo. Como consequéncia, os periodos em que esses gastos forem realizados em grande proporcăo terão os seus resultados subavaliados, enquanto que os periodos posteriores, beneficiados pelas patentes descobertas a custo contābil zero, terão seus resultados su peravaliados.

A ativacão desses gastos como custos das patentes, förmulas e processos descobertos no futuro, conforme proce dimento do item iv, restabeleceria maior realidade nos demonstrativos contābeis, alēm do que não seria de difícil execução.

c. PROPAGANDA E PUBLiCidADE, Da mesma forma, os gastos com Propaganda e Publicidade, conforme o ramo de atividade da empresa e o grau de concorréncia nele existente, podem cons tituir-se em um dos seus itens de despesa mais relevantes. Igualmente, são gastos cujos efeitos se projetam no futuro e a Contabilidade, face a dificuldade de se medir esses efeitos e o tempo de sua duracão, prefere tratā-los como 
despesas no momento de suas ocorrēncias, distorcendo os resultados e prejudicando a comparabilidade das demonstraçoes.

A proposito desses gastos paton (63), discordando do tratamento a eles dispensado pela prātica contābil, pon derou:

"Encouraged by acceptance from many years of the view that selling costs, including advertising, are generally deductible for tax purposes in the period in which incurred, conventional accounting has long been on an arbitrary course in this area. The fact remains that is basically improper to include in current operating costs substantial amounts that are clearly associated with future product shipments, and in connection with business enterprise transfers and combinations the rights of some of the parties involved may be impaired by slavish adherence to the conventional - and illogical - procedures ... Dealing realistically with advertising and other marketing promotion programs is of course more difficult than the periodic allocation of the cost (or value) of activities related to particular orders for product, but it doesn't follow that the problem should be ignored. What is badly needed is the encouragement of

(63) Paton, William A.-"Comentārios ao Accounting for Coodwill" de George R. Catlett e Norman 0. Olson, ARS n? 10 AICPA, 1968 p. 144. 
careful study and analysis instead of adoption of the easy-going view that general goodwill is all that we can find in the area of intangible resources".

Os gastos com propaganda e publicidade estão int mamente relacionados com o valor do goodwill, na medida em que podem provocar um aumento nos lucros futuros da empresa ou evitar a sua queda, bem como podem fortalecer essa capa cidade de lucros futuros da empresa de uma forma mais ampla.

Embora menos aceita a sua ativacão, pelas razões acima, existem métodos estatísticos de apuração da efetivi dade de propaganda $(64)$, em termos do grau de influência nas vendas e do tempo de sua duração, sendo justificável à sua ativação e amortização de acordo com a experiēncia passada, uma prática já tradicional na contabilidade.

Sendo praticamente impossível a determinacão do efeito indireto desses gastos, i.e.e, em termos de fortalec $\underline{j}$ mento da marca e da fidelidade dos clientes, a aplicaça do critērio do "matching" para sua inteira amortizacão fificaria justificada.

d. AVALIAÇÃO DO GOODWILL

0 valor do goodwill sinergistico aproximado seria apurado pela diferenca entre o valor atual dos lucros futu ros da empresa e o valor económico dos ativos identifica -

(64) Dean, Joel - "Economia das Empresas", Ed. Fundo de Cul tura, R.J., 1962 . 
dos e contabilizados, incluidos os recursos humanos, Pes quisa e Desenvolvimento e Propaganda e Publicidade.

A mensuração resultante, entretanto, embora relevante, teria um alto grau de subjetividade.

\subsection{TRATAMENTOS CONTÁBEIS ADOTADOS}

\subsubsection{GOODWILL UM INCONVENIENTE INEVITÁVEL?}

0 aparecimento do goodwill, em decorréncia da aquisicão de empresas, tem sido um incomodo para os conservadores, em face da necessidade de se dispensar a ele um tratamento contābil, por jā não ser ignorāvel. Justifica se dessa forma o posicionamento daqueles que julgam ser a baixa do goodwill, contra reserva de capital ou de lucros, o tratamento contābil mais adequado, conforme será abordado mais adiante.

A mesma filosofia estā subjacente ao não reconhecimento do goodwill não adquirido, muito embora o volume crescente de gastos com pesquisa e desenvolvimento e propa ganda e publicidade induzam a conclusão de que o total dos ativos náo contabilizados estejam a cada dia aumentando pro porcionalmente ao ativo total, distorcendo as anālises e prejudicando a tomada de melhores decisões. 


\subsubsection{GOODWILL NÃO ADQUIRIDO X GOODWILL ADQUIRIDO}

3.2.2.1. DISTORÇ̃ES DECORRENTES DO NÃO RECONHECIMENTO DO GOODWILL NÃO ADQUIRIDO E PROCEDIMENTOS CONTÁBEIS RELATIVOS AOS GASTOS COM GOODWILL

Uma das primeiras distorcões geralmente levanta das por aqueles que defendem o reconhecimento e contabilizaça do goodwill não adquirido é a irrealidade dos demons trativos, especialmente os balanços, onde deveriam apare cer todos os ativos responsáveis pelo desempenho da empre sa - isso não sendo possivel, aqueles de dificil identificação e mensuração individualizada poderiam ser contabilizados a tîtulo de goodwill não adquirido. A não realização desse tratamento contábil faz com que ativos importantes continuem ocultos, diminuindo o valor dos balanços como fonte de informação para os usuários externos.

A existencia desses ativos ocultos, por outro lado, distorce os indices de mensuracão do desempenho, alterando a lucratividade sobre o ativo e mesmo afetando o prō prio lucro do periodo.

Empresas similares e com desempenhos reais semelhantes poderiam ter lucratividades e situacões patrimoniais totalmente diferentes, em função apenas do fato de uma ter adquirido o goodwill e a outra desenvolvido o seu próprio, que năo é reconhecido pela Contabilidade. Dessa forma, fica prejudicada a comparabilidade dessas empresas,atra vés dos seus demonstrativos convencionais e mesmo entre exercicios sociais diferentes da mesma empresa. 
Como consequência dessa prática, os gastos relacio nados com o goodwill não adquirido e/ou manutenção do adqui rido são todos considerados como despesas no exercício social de suas ocorrências, em funçao, entre outros, dos seguintes argumentos:

- dificuldade de vincular os gastos com a geracão do goodwill e o periodo da ocorréncia dos beneficios;

- flutuacão do goodwill sem relacão possível com o seu custo;

- goodwill não pode ser medido em termos de dinheiro gasto para criā-lo;

- impossibilidade, em geral, de identificacão do goodwill com fatores ou gastos especificos.

Essa.prātica vai de encontro ao critērio do "matching", sem pre invocado pelos conservadores na apuraça do lucro empresarial, pois, ignora-se completamente o principio da causa e efeito - os efeitos são normalmente mensurados, porém, nem sempre as causas são a eles associados. Assim, os demonstrativos po dem revelar variacões bruscas nos resultados da empresa, ape nas como consequēncia desses procedimentos contābeis.

3.2.2.2. JUSTIFICATIVAS APRESENTADAS PARA O NÃO RECONHECI MENTO DO GOODWILL NÃO ADQUIRIDO

Basicamente, essas justificativas giram em torno de trēs pontos, a saber: a necessidade de atender a conven- 
cão do conservadorismo, a ausência de base para determinar o goodwill não adquirido e o fato de a Contabilidade ser baseada no custo.

Por outra lado, se se reconhecer e contabilizar o goodwill não adquirido, a demonstração de resultado da empresa nao mostraria o seu sucesso en consenuir super-lucros, mas tenderia a mostrar algum tipo de lucros normais. A capacidade acima do normal da empresa seria eliminada pela amortizacao do goodwill reco nhecido e os lucros resultantes tenderiam a indicar un retorno normal. Paton $(65)$ acredita não ser nem racional e nem pra-
ticãvel uma empresa reconhecer em suas contas o valor capi
talizado de uma parte de seus prováveis lucros futuros.
Não obstante, esses argumentos contra o goodwill não adquirido, George 0 May ${ }^{(66)}$, julgando exagerada a ēnfa se na forma de obtencão como critério de reconhecimento,fez - seguinte comentārio ao chamar atencão sobre a inconsis tência do "Accounting Research Study" no 48:

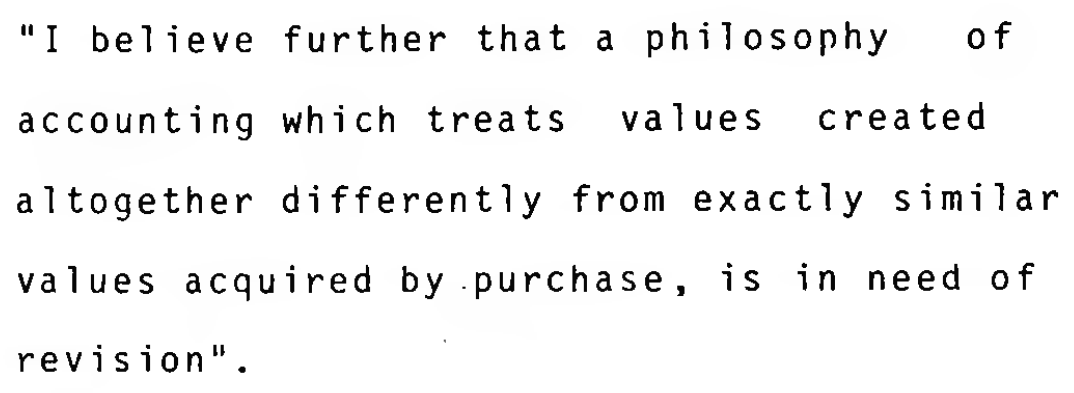

0 conservadorismo e o Custo como base de valor, principais fundamentos dos argumentos utilizados para o

(65) Paton, William A. - "Accounting Theory", Accounting Studics Press Ltd., 1962 p.307/332.

(66) May, Geurge 0. - "Business Combination: An Alturnate Vicw", Journal of Aceountancy, Apr./1957. p. 33/36. 
não reconhecimento, são atualmente dois dos maiores alvos dos crīticos da teoria contābil, o que jă foi abordado no presente trabalho. Relativamente a auséncia de base para determinar o goodwill não adquirido, Cattlet e 01 son (67) su gerem a utilizacão do valor de mercado da acão da empresa, o qual julgam melhor também para mensurar o goodwill adqu $\underline{i}$ rido.

E interessante ainda registrar, como demonstracão da incoerência dos argumentos utilizados, que, as vezes eles servem a fins opostos. Por exemplo: quando, uma vez adquirido e contabilizado o goodwill,e constata-se nos anos seguintes, que o goodwill da empresa permaneceu constante ou sofreu aumentos, os conservadores que defendem a amort $i$ zação do goodwill adquirido, atribuem tal constância ou au mento ao goodwill desenvolvido pela prōpria empresa, embora se oponham ferrenhamente em reconhecê-10. Como assegu rar-se dessa variacão, sem o conhecimento do comportamento das duas variāveis: o goodwill adquirido e o não adquirido?

A mistura do goodwill adquirido e não adquirido, sem pre vai ocorrer, na medida em que houver aquisicões de outras empresas e pode-se afirmar que não serā possível um tratamento adequado do goodwill adquirido, se o não adquirido continuar a ser ignorado.

o tratamento contābil para o goodwill não adquiri do não necessariamente terā que ser igual aquele dispensado ao adquirido, pelo fato deste ūltimo envolver uma tran-

(67) 0p.cit.p. 13/14. 
saçào, que implica numa movimentação de recursos no momento do seu reconhecimento. Uma solucáo possível para a contrapartida do reconhecimento do goodwill não adquirido seria a criacão, no patrimōnio liqquido, de conta similar a reserva de reavaliacăo (exemplo: Reserva Especial Goodwill não Adquirido).

Finalmente, para resguardar-se contra eventual subjetividade desses dados, o seu "disclosure" poderia ser efetuado em demonstrativos paralelos, apresentados ao lado dos convencionais.

\subsubsection{EXEMPLOS DE DISTORÇÕES}

\section{a. DADOS EXISTENTES SOBRE EMPRESAS:}

a.1. Empresas $A$ e $B$ iniciaram atividades no final de de $19 \times 0$ produzindo produtos similares;

a.2. No inicio de $19 \times 1$, a empresa $A$ gastou CZ $\$ 800.000,00$ em Pesquisa e Desenvolvimerito de produtos, enquanto a empresa $B$ adquiriu a empresa $C$, tendo pago adi cionalmente ao seu patrimōnio líquido Cz $\$ 800.000,00$, face sobretudo ao processo especial de producão que a ūltima desenvolvera (vida útil restante estimada de 5 anos), correspondente a cerca de $90 \%$ daquele valor.

a.3. As empresas A e B tinham no final de $19 \times 0$ um igual valor para o Ativo e o Patrimōnio Líquido,os quais montavam Cz $\$ 700.000,00$. 
a.4. No inicio de $19 \times 2$, a empresa $A$ logrou éxito em suas pesquisas, delas resultando a descoberta de "fórmula especial" que permitiria diminuir os custos unitārios e consequentemente elevaria as vendas ao dobro, pelo menos nos prōximos 10 anos, além de contribuir grandemente na melhoria da imagem da empresa.

b. HIPÓTESES ASSUMIDAS:

b. 1. Invariabilidade dos precos, de forma que o custo his tórico é igual ao custo de reposicão.

b.2. Acredita-se que as situacões presentes se repetirão no futuro.

b. 3. Ambas as empresas continuarão a utilizar as mesmas politicas no futuro.

b.4. Não houve distribuicão de lucros em $19 \times 1$.

b.5. 0 goodwill prōprio, i.é, o não adquirido, sō será apurado em $19 \times 2$.

c. DEMONSTRACÕES CONVENCIONAIS: 
d. DEMONSTRAÇOES COM GOODWILL NÃO ADQUIRIDO:

BALANÇOS PATRIMONIAIS EM 3].12.19XI

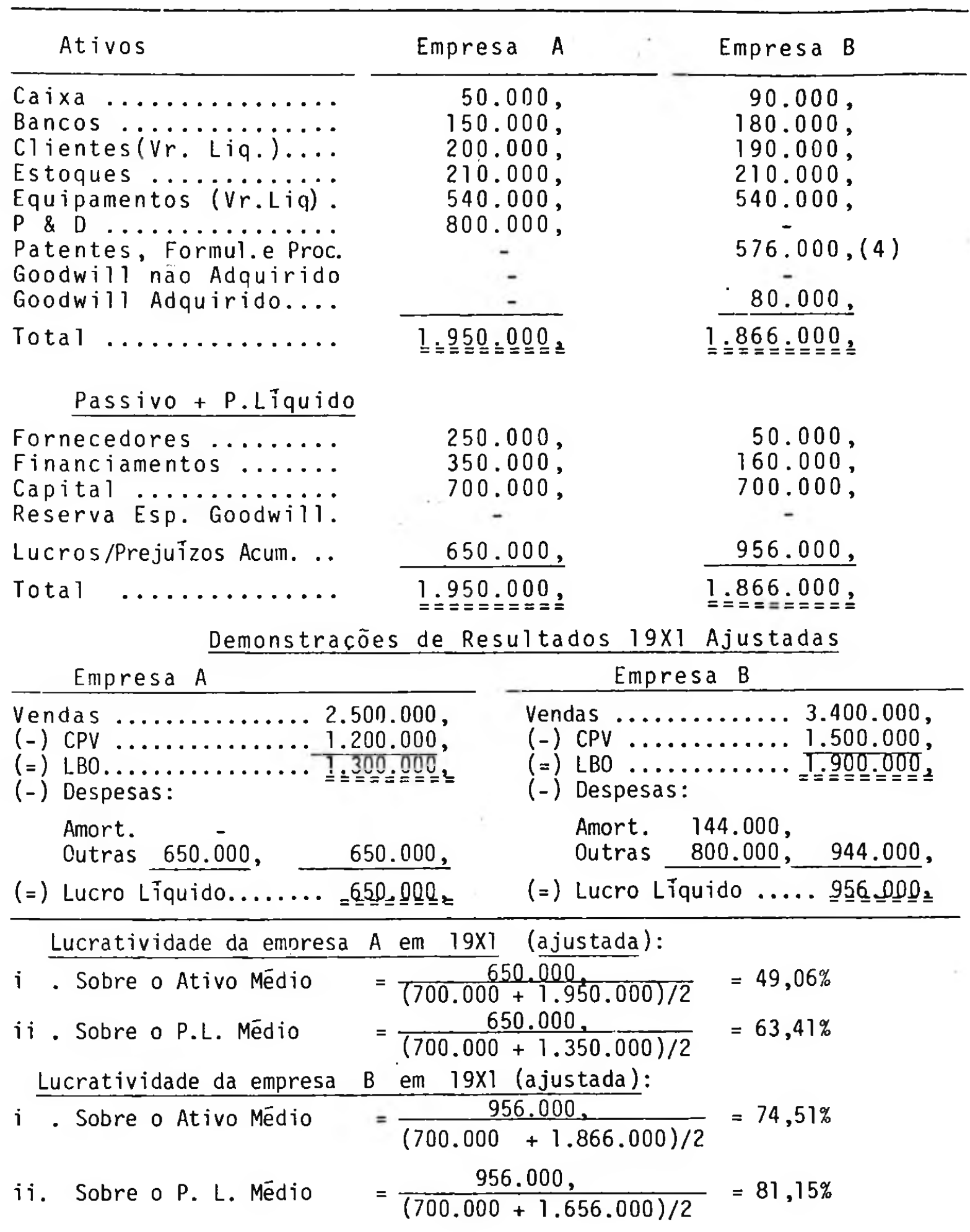


BALANCOS PATRIMONIAIS EM 3.1,12.19X1

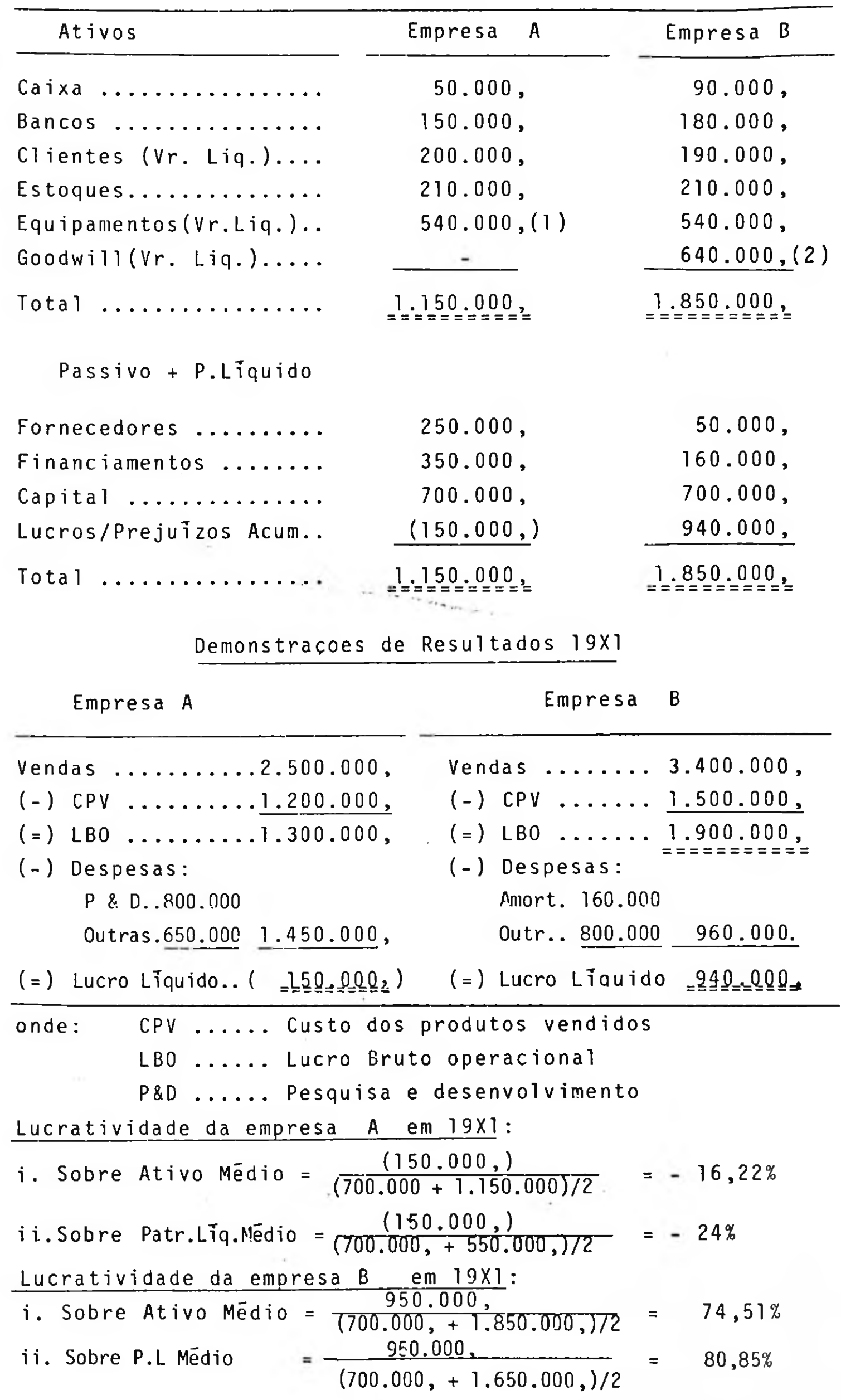


BALANÇOS PATRIMONIAIS EM 31.12.19X2

\begin{tabular}{|c|c|c|}
\hline Ativos & Empresa $A$ & Empresa \\
\hline 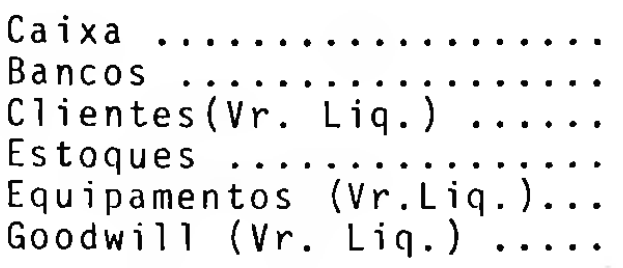 & $\begin{array}{l}310.000 \\
720.000 \\
820.000 \\
420.000 \\
480.000 \\
-\end{array}$ & $\begin{array}{l}280.000, \\
700.000, \\
640.000, \\
340.000, \\
480.000, \\
480.000,\end{array}$ \\
\hline Total & 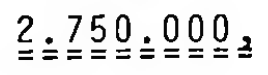 & 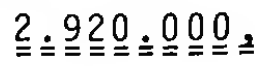 \\
\hline \multicolumn{3}{|l|}{ Passivo + P. Lịquido } \\
\hline $\begin{array}{l}\text { Fornecedores } \ldots \ldots \ldots \ldots \\
\text { Financianientos } \ldots \ldots \ldots \ldots \\
\text { Capital } \ldots \ldots \\
\text { Lucros/Prejuizios Acum. }\end{array}$ & $\begin{array}{r}150.000 \\
50.000 \\
700.000 \\
1.850 .000\end{array}$ & $\begin{array}{r}230.000 \\
150.000 \\
700.000 \\
1.840 .000\end{array}$ \\
\hline Total $\ldots \ldots \ldots \ldots \ldots$ & 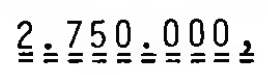 & $\stackrel{2}{=} \stackrel{9}{=} \stackrel{2}{=}=\stackrel{000}{=}=\underline{=}=$ \\
\hline
\end{tabular}

Demonstracões de Resultados $19 \times 2$

Empresa A

Vendas ......55.000.000,

(-) CPV........... 1.800 .000 ,

$\Leftrightarrow \quad \angle B O \ldots \ldots \ldots \ldots 1.300 .000$,

(-) Despesas:

Amort.

Outras 1.200.0001.200.000,

( ) ) Lucro Liquido ..2.000.000,
Empresa $B$

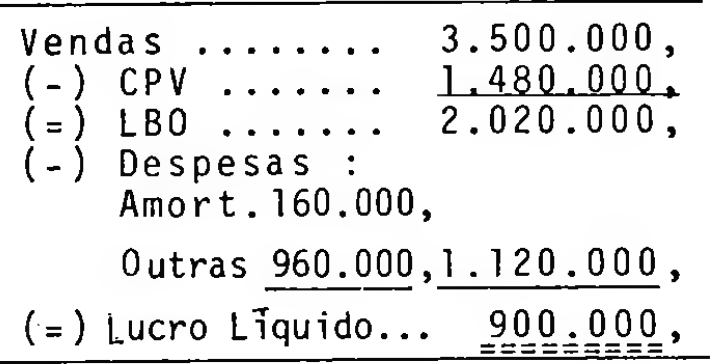

Lucratividade da empresa A em 19x?:

$i$. Sobre Ativo Médio $=\frac{2.000 \cdot 000,}{(1.150 .000+2.760 .000) / 2}=51,28$

ii . Sobre P.L. Médio $=\frac{2.000 .000,}{(550.000+2.550 .000) / 2}=64,52 \%$

Lucratividade da empresa $B$ em 19x2:

$i$. Sobre Ativo Médio $=\frac{900.000,}{(1.850 .000+2.920 .000) / 2}=37,74 \%$

ii. Sobre P. L. Médio $=\frac{900.000}{(1.650 .000+2.540 .000) / 2}=42,96 \%$ 
BALANCOS PATRIMONIAIS EM 31.12.19X2

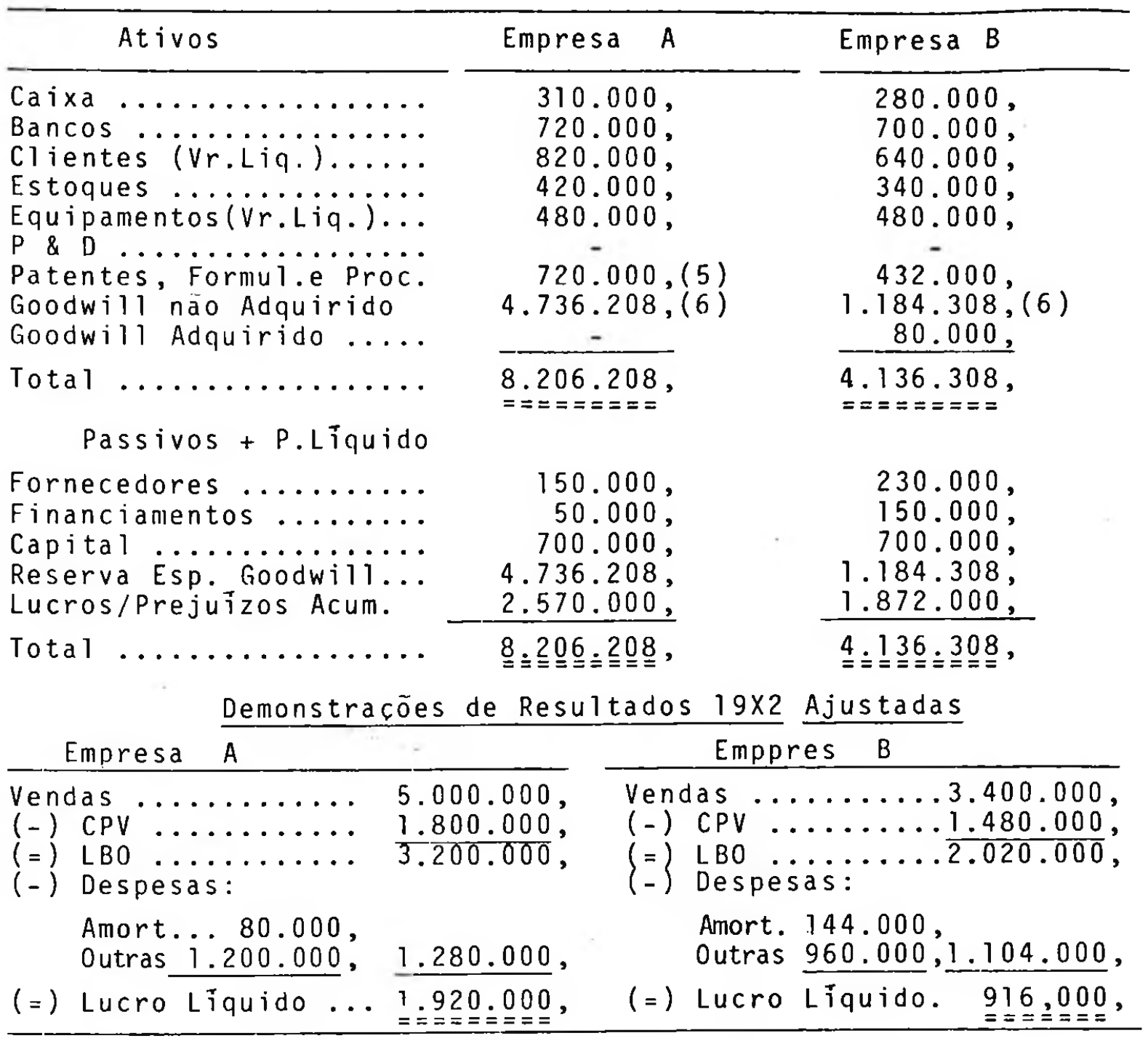

Lucratividade da empresa A em $19 \times 2$ (ajustada):

$i$. Sobre o Ativo Médio $=\frac{1.920 .000,}{(1.950 .000+8.206 .208) / 2}=37,81 \%$

i i. Sobre o P.L. Mëdio $=\frac{1.920 .000,}{(1.350 .000+8.006 .208) / 2}=41,04 \%$ Lucratividade da empresa B em 19x2 (ajustada):

$i$. Sobre o Ativo Médio $=\frac{916.000,}{(1.866 .000+4.136 .308) / 2}=30,52 \%$

ii. Sobre o P. L.Mëdio $=\frac{916.000}{(1.656 .000+3.756 .308) / 2}=33,85 \%$ 
e. OBSERVACÕES:

1) Os equipamentos de ambas as empresas foram adquiridos no inicio de $19 \times 1$, sendo as vidas úteis estimadas em 10 anos, com depreciaça pelo método da linha reta;

2) A empresa B amortiza o goodwill, considerando que 0 valor adicional, pago em relaçăo ao património líquido da adquirida, repousa preponderantemente no processo especial recebido na transação. Perĩodo de amortização: 5 anos;

3) A utilização da conta "Reserva Especial Goodwill" para a contrapartida da contabilizacão do Goodwill não ad quirido será justificada mais adiante;

4) Considerando-se que $90 \%$ do valor adicional corresponde ao valor. do processo especial adquirido, foi feita a separaçäo na contabilidade, aplicando-se a esse valor a amortização.

5) Registrou-se a förmula especial descoberta, tendo como custo os gastos com $P$ \& D efetuados. A vida ūtil estimada foi de 10 anos.

6) Cálculo do goodwill não adquirido, considerando hori zonte de 5 anos a taxa de desconto de 10\% a.a.: 


\begin{tabular}{|c|c|c|c|}
\hline Empresa $A$ & & Empresa & B \\
\hline Lucro Lĩquido Anual & 1.920 .000 & & $920.000,\left(^{*}\right)$ \\
\hline \multicolumn{4}{|l|}{ Valor Atual Lucros } \\
\hline Futuros (fator 4.1699) & 8.006 .208 & & 3.836 .308 \\
\hline P.L. em $31.12 .19 \times 2$ & 3.270 .000 & & 2.572 .000 \\
\hline Goodwil1 $\ldots \ldots \ldots$ & 4.736 .208 & & 1.264 .308 \\
\hline Goodwill Adquirido & - & & 80.000 \\
\hline Goodwill não Adq. . & 4.736 .208 & & 1.184 .308 \\
\hline & & (*) Mëdia & $=\frac{940.000+900.000}{2}$ \\
\hline
\end{tabular}

7) Os ativos sendo avaliados pelos seus custos histōricos (nesse caso considerados iguais aos de reposicäo), ao in vēs do valor econōmico, eles estão geralmente subavaliados, resultando um goodwill maior. Por outro lado, a em presa $B$, deve acautelar-se quanto ao seu futuro, se 0 seu goodwill baseia-se fortemente no processo especial adquirido, pois sua vida útil estimada $\bar{e}$ relativamente curta.

3.2.3. FORMAS DE TRANSAÇÃO E GOODWILL

\subsubsection{CONTABILIDADE DE AQUISICÃO("PURCHASE ACCOUNTING")}

Compreende todas as aquisicões de empresas em que o valor da transacao é efetuado em dinheiro, titulos ou outras propriedades. Todos os ativos adquiridos são registrados pelo seu valor considerado justo, inclusive o goodwill, que corresponde a diferenca entre o valor pago e. o valor daqueles ativos. 
Nesse método, faz-se clara distinção entre os periodos financeiros da adquirente e da adquirida, sendo o exercicio social da adquirida fechado na data da transacao.

Registrando os ativos da adquirida pelos seus valo res correntes e näo os valores contābeis histōricos, e reconhecendo o valor do goodwill pago, o "purchase accounting" efetua um "disclosure" da transacão ocorrida para os usuá rios das informacōes contäbeis.

\subsubsection{CONTABILIDADE DE FUSĀO DE INTERESSES ("POOLING ACCOUNT ING")}

Caracteriza-se o "pooling" quando ocorre uma tran sacao com troca de acoes votantes de uma empresa e acionistas de outra entidade, resultando em uma nova entidade, mas sem a necessidade de uma nova base para a contabilidade da mesma. Muito embora o goodwill seja atē avaliado na transacäo, para efeito da troca de acoes, ele näo é reconhecido na Contabilidade da sucessora, que registra os dados contábeis consolidados pelos seus valores contābeis históricos, desconsiderando os valores justos dos ativos.

Nos EUA, esse método de transacão tem sido estimu lado face disposicão do "Internal Revenue Service", o Impos to de Renda americano, que isenta as trocas de titulos, enquanto tributa as operacões com pagamento em dinheiro.

A năo contabilização, do goodwill, a inexistēncia de reajustes nos valores dos ativos a custos histöricos e a continuidade dos exercicios sociais, como se nada tivesse 
corrido, seriam outras vantagens reclamadas para o "pooling" por seus defensores.

A caracterizacäo da ocorréncia do "pooling", nem sempre fácil de ser realizada, o "pagamento" com ações seria complementado pela presenca das seguintes situacóes:

a. interesses dos acionistas continuam na mesma proporção na empresa sucessora.

b. empresas fusionadas tem tamanho não muito desproporcio nais uma em relação a outra;

c. administrações mantēm a mesma influēncia na sucessora;

d. atividades de negōcios das constituintes são similares ou complementares.

3.2 .3 .3$. "PURCHASE $X$ POOLING"

Conduzindo a situações totalmente distintas, tanto em relação aos demonstrativos contābeis, como as mensurações de desempenho da sucessora e reconhecimento do goodwill, a escolha entre esses mētodos tem merecido, nos EUA, muito aten ção por parte dos estudiosos da Contabilidade.

Atualmente o "Purchase" e o "Pooling" tem sido acei tos como métodos alternativos para as combinacões de negō cios que envolvem transacão de ações votantes.

0 mētodo do "Pooling" esconde a realidade da transacão aos usuārios das informaçoes contābeis, pois simplesmente soma os ativos contábeis histöricos, registrando toda 
a diferenca entre o valor da transacào e os valores histór cos como àgio (reserva de capital), enquanto o método do "Purchase" faz um "disclosure" do valor da empresa adquirida, năo só reconhecendo o valor do goodwill, como também agregando os ativos adquiridos pelo custo corrente.

$$
\text { Fischer, Taylor e Leer }{ }^{(68)} \text { elaboraram } 0 \text { seguinte }
$$

quadro comparativo dos procedimentos prescritos pelos dois mētodos:

QUADRO 3.3

\begin{tabular}{|c|c|c|}
\hline I tem & Mētodo Purchase & Método Pooling \\
\hline $\begin{array}{l}\text { 1. Registro de At } \underline{i} \\
\text { vos e Exigibili } \underline{-} \\
\text { dades. }\end{array}$ & $\begin{array}{l}\text { Aos valores correntes de } \\
\text { mercado com possibilidade } \\
\text { de ocorréncia de goodwill. }\end{array}$ & $\begin{array}{l}\text { Aos valores contäbeis da } \\
\text { firma adquirida. Não re- } \\
\text { conhecimento de goodwill } \\
\text { adicional }^{(a)} \text {. }\end{array}$ \\
\hline $\begin{array}{l}\text { 2.Titulos emiti - } \\
\text { dos }\end{array}$ & $\begin{array}{l}\text { Valor de mercado das a- } \\
\text { cões adicionadas ao capi- } \\
\text { tal integralizado. }\end{array}$ & $\begin{array}{l}\text { Capital integralizado da } \\
\text { firma adquirida transfe- } \\
\text { rido como valor integra- } \\
\text { lizado das açöes emiti - } \\
\text { das (b). }\end{array}$ \\
\hline $\begin{array}{l}\text { 3. Lucros Retidos } \\
\text { da firma adqui- } \\
\text { rida. }\end{array}$ & Não reconhecidos. & $\begin{array}{l}\text { Somados aos lucros reti- } \\
\text { dos (b) }\end{array}$ \\
\hline
\end{tabular}

(a) goodwill previamente contabilizado pela firma adquirida seria registrado pelo valor contābil.

(b) os lucros retidos da firma adquirida podem ser reduzi dos para chegar-se ao valor ao par ou declarado da emitente.

(68) Fischer, Paul, Tilylor William James a Leer J.Arthur "Avanced Accounting" - South Western Publ. Co, Cincinati. California,1978, pg. 145. 
Não se pode ignorar as alteracões provocadas

estrutura patrimonial da sucessora, motivada pela combinacão, assim como nào parece ser lógico ajustar para valores correntes apenas os ativos da adquirida.

0 reconhecimento e contabilizacão do goodwill nào adquirido e o registro de todos os ativos em bases correntes, "disclosure" jā exigido para algumas empresas america nas, reduziria, sem dūvida, a grande distāncia existente en tre os dois métodos, amenizando as distorcões decorrentes do uso de um ou outro método, o que seria de grande utilidade para os usuários.

Suponha-se duas empresas similares Alfa e Beta e as seguintes situações:

a. BALANCETES DE VERIFICACÃO EM 30,12,19X3:

\begin{tabular}{|c|c|c|c|}
\hline & $\mathrm{Alfa}$ & Beta & $\begin{array}{l}\text { Valor de } \\
\text { Mercado - Beta }\end{array}$ \\
\hline 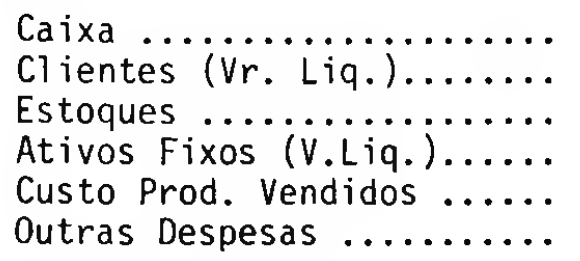 & $\begin{array}{r}950.000 \\
1.400 .000 \\
1.000 .000 \\
1.800 .000 \\
2.000 .000 \\
650.000 \\
\end{array}$ & $\begin{array}{l}150.000 \\
400.000 \\
300.000 \\
700.000 \\
650.000 \\
200.000\end{array}$ & $\begin{array}{r}150.000 \\
400.000 \\
500.000 \\
1.000 .000\end{array}$ \\
\hline Total Dēbitos $\ldots . . . \ldots \ldots$ & 8.800 .000 & 2.400 .000 & \\
\hline 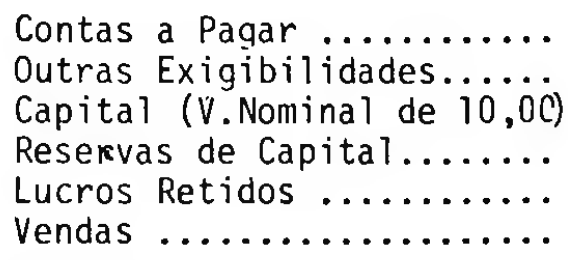 & $\begin{array}{r}600.000 \\
400.000 \\
2.000 .000 \\
400.000 \\
1.300 .000 \\
3.100 .000 \\
\end{array}$ & $\begin{array}{r}360.000 \\
240.000 \\
600.000 \\
80.000 \\
220.000 \\
900.000\end{array}$ & \\
\hline Total Crēditos ............ & 8.800 .000 & 2.400 .000 & \\
\hline
\end{tabular}

b. A transação entre as empresas concretizou-se em $31.12 .19 \times 3$ com a Alfa, a empresa sobrevivente, emitindo 60.00 n açōes comuns ao valor nominal de 10,00 (valor de mercado 30,00 ), näo tendo havido cus tos para reqistro e emissão destas. 
QUADRO 3.4. - ANÁLISE COMPARATIVA "PIJRCHASE POOLING"

CONTABILIDADE DA EMISSÃO DE TIITULOS

\begin{tabular}{|c|c|c|c|c|}
\hline \multirow{2}{*}{$-\frac{\text { Data } / \text { Operação }}{31.12 .19 \times 3 .}$} & \multicolumn{2}{|c|}{ Purchase } & \multicolumn{2}{|c|}{ Pooling } \\
\hline & & & & \\
\hline $\begin{array}{l}\text { Investimento enl Beta: ... } \\
\text { Ágio...................... } \\
\text { Lucros Retidos ............ }\end{array}$ & 1.800 .000 & $\begin{array}{l}600.000 \\
1.200 .000 \\
-\end{array}$ & 900.000 & $\begin{array}{r}600.000 \\
80.000 \\
220.000\end{array}$ \\
\hline \multicolumn{3}{|c|}{ Alocacäo do Investimento em } & Beta & \\
\hline \multicolumn{5}{|l|}{$31.12 .19 \times 3:$} \\
\hline Caixa $\ldots \ldots \ldots \ldots \ldots \ldots$ & 150.000 & & 150.000, & \\
\hline Clientes (V.Lĩquido)........ & 400.000 & & 400.000 , & \\
\hline Estoques $\ldots \ldots \ldots \ldots \ldots$ & 500.000 & & 300.000 , & \\
\hline Ativos Fixos(V.Liquido).... & 1.000.000, & & 700.000 & \\
\hline Goodwill.............. & $350.000,(1)$ & & - & \\
\hline Custo Produtos Vendidos ... & - & & 650.000 , & \\
\hline Outras Despesas ........... & - & & 200.000 , & \\
\hline Contas a Pagar............. & & 360.000 & & 360.000 \\
\hline Outras Exigibilidades ... & & 240.000 & & 240.000 \\
\hline Vendas $\ldots \ldots \ldots \ldots \ldots \ldots$ & & - & & 900.000 \\
\hline Investimento em Beta .... & & 1.800 .000 & & $900.000,(2)$ \\
\hline
\end{tabular}

\section{Observações:}

1. Goodwill = Valor do Investimento - Patrimônio Líquido

$$
\begin{aligned}
& =1.800 .000,-(2.050 .000,-600.000,) \\
& =1.800 .000,-1.450 .000,
\end{aligned}
$$

2. Valor Contābil Histórico do Patrimônio Lỉquido de Beta em $31.12 .19 \times 3$. 


\section{OUADPD 3.5. - ANIALISE CO!IPARATI'A "PUPCHASE -POOLING"}

\section{EMPRESA ALFA - BALANCOS PATRIMONIAIS EM 31.12.19Y3}

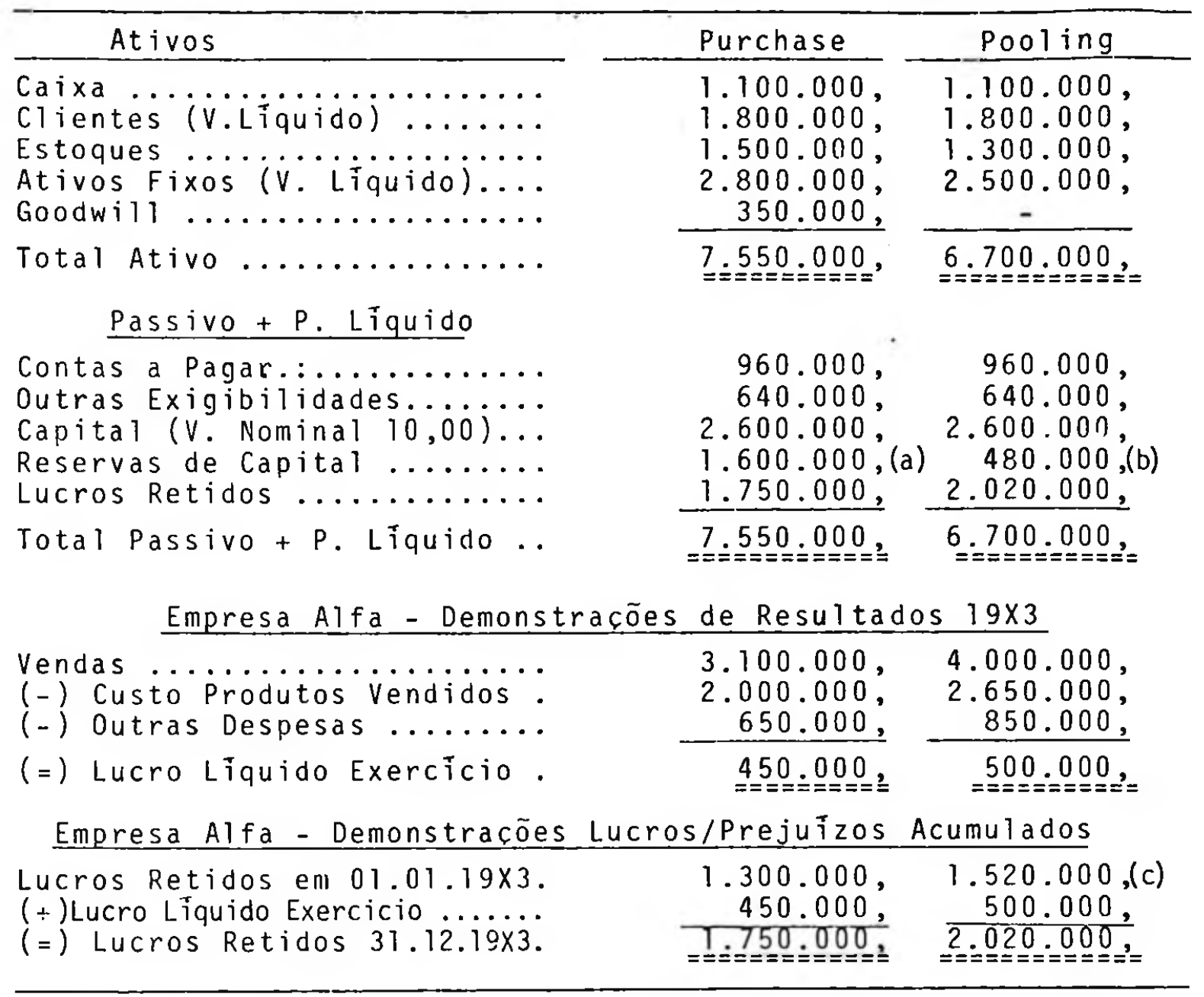

\section{Observações:}

a. Reservas de Capitai Final = Reserva Capital Inicial + Agio Transaçäo $=400.000+[(60.000 \times 30)-(60.000 \times 10)]=$ $==1.600 .000$

b. Reservas ite Capital Final $=[(2.000 .000+400.000)+$ $(600.000+80.000)]-(2.000 .000+600.000)=\underline{480.000}=$

c. Lucros Retidos Final = Lucros Retidos Alfa Inicial + Lucros Retidos Beta Inicial + Lucro Líquido Exercício Alfa = $1.300 .000+220.000+500.000==1.520 .000=$ 
Considerando esses dados, o Quadro 3.4. mostra a contabilizacăo da emissão dos tîtulos e da alocacão do investimento, e, o Quadro 3.5., o Balanço Patrimonial e a De monstracão de Resultados, ambos os quadros com a anālise comparativa entre os dois métodos.

os retornos sobre o ativo e o património líquido apresentam diferencas, conforme seja utilizado um ou outro método, tanto em funcão de diferencas no lucro decorrente da forma de tratamento de receitas e despesas (continuacão do periodo financeiro no pooling), no exercício da transacão, e do Custo dos Produtos Vendidos e Despesas de Depre ciação, nos exercícios subsequentes, como também em consequéncia de valores diferentes para os Ativos e Patrimónios Lìquidos.

3.2.4. PROCEDIMENTOS ADOTADOS QUANTO AO GOODWILL ADQUIRIDO 3.2.4.1. AMORTIZACẼO GRADATIVA

E o procedimento mais difundido, estando entre os seus defensores Yang, Paton e Littleton e Dyckman (69), pois: - o goodwill como qualquer outro ativo seria um custo antecipado dos lucros futuros, devendo ser amortizados pela aplicacão do "matching" com as receitas decorrentes;

- a não ser que o goodwill pago fosse atribuível apenas aos lucros subsequentes, o lucro do exercicio não estaria cor reto se todos os custos não. fossem computados na sua apu racão, ocorrendo sua superavaliação se a amortizacão do

(69) Apud Norton M. Bedford e F. James Burton - "Coodwill" in Davidson, Sidney \& Wail, Roman l.., "llandbook of Modern Accounting" Mcciraw-llill book Co, 1977, p. 2l-19. 
goodwill não fosse incluĩda;

- os procedimentos da negociacão indicariam, por outro lado, a base para a realização da amortizaçäo;

- o goodwill adquirido representaria um valor decorrente de um conjunto de circunstancias e o seu custo deveria ser amortizado de acordo com a natureza dessas circunstäncias;

- o goodwill adquirido deveria ser sempre amortizado, pois seria dificil admitir a continuaça de sua existēncia no futuro - a sua constāncia ou aumento seria atribuivel ao goodwill não adquirido, originado dos gastos com pesqui sa e desenvolvimento e propaganda e publicidade.

Muito embora mais sustentável que a baixa imediata, que apenas livra-se do problema sem resolvē-lo, a amortizacäo gradativa encontra sérias dificuldades präticas relacio nadas primeiramente com a diminuicão ou não do valor do goodwill e, em seguida, com o prazo de sua duração - só com a determinacào do periodo de existéncia do goodwill a aplicação da amortização ficaria plenamente fundamentada.

Em função da quase impossibilidade da determinacão da durabilidade do goodwill adquirido, que se confunde com o não adquirido, após a transação, vārios são os procedimen tos adotados para a realização da amortizacão:

a. considerando vida ūtil máxima de 40 anos (maior vida ütil atribuivel a ativos tangiveis) - o que poderia acarretar num resultado não muito distante da não amortização, se o valor do goodwill adquirido não fosse muito elevado em relação ao faturamento da empresa;

b. considerando o horizonte utilizado para a projecão dos 
lucros (apuração do goodwill), como o perỉodo de existên cia do goodwill - um dos procedimentos mais utilizados, assim justificado por Yang $(70)$ :

"...The logical principle seems to be that the assets should be written off during the periods for which the excess earnings were capitalized when calculating the purchase price".

Da mesma forma, Paton e Littleton (71) defenderem essa forma de deterninaça do periodo para amortizaçäo, independentemente da persistencia da capacidade superior de lucros, pois não haveria meio de demonstrar a sua associação com o goodwill adquirido.

c. considerando outro prazo qualquer para a duracão do goodwill, se estimāvel - aparentemente, seria mais razovel a sua utilização, porem, o grande obstáculo continuria sendo a dificuldade da sua correta estimaça, podendo redundar numa amortização arbitrāria.

Não estando afastada a possibilidade da perenidade do goodwill, não seria razoāvel proceder sempre a sua amortização, mesmo utilizando um prazo artibrārio, simplesmente para atender ao "matching". (existem receitas, portanto, de ve haver despesas). Além disso, muitos dos fatores relacio

(70) Apud George R. Catlett e Norman 0. Olson - "Accounting for Cinolwill", ARS 10 NIC.PA, 1968 p. 41.

(71) Id lbid. P. 4l. 
nados com o goodwill, aos quais dever-se-ia atribuir amort $\underline{\mathbf{i}}$ zação, são de fato ativos identificāveis e avaliāveis sepa radamente, devendo ser tratados como tal - ogoodwill, excluídos esses valores, teria a sua vida útil associada a duraça da empresa, podendo apenas sofrer variacoes no seu valor. Finalmente, o argumento utilizado para defender a diminuição do goodwill adquirido, atribuindo a continuação ou aumento da capacidade de lucro, ao desenvolvimento do goodwill não adquirido, apenas confirma a necessidade do seu reconhecimento e de tratamento contábil deste ultimo se isso não ocorrer, o goodwill adquirido fica prejudicado no seu tratamento.

\subsubsection{ATIVAÇÃO E MANUTENÇÃO DO GOODWIILL INALTERADO}

Sendo impossivel obter evidências da diminuicão do valor do goodwill e considerando que as demonstracoes financeiras não seriam instrumentos häbeis de mensuracão da performance administrativa, se o retorno fosse afetado por amortizacoes arbiträrias ou baixa do goodwill, a melhor so lucão seria a ativacão e manutencão do goodwill pelo seu valor inalterado - as atividades administrativas, por outro lado, manteriam o seu valor indefinidamente.

Hamilton ${ }^{(72)}$ um dos defensores desse procedimento, assim afirmava, contraditando Leake:

"As to the propriety of a company's writting

72) Apud George R. Catlett e Norman 0. 01son - "Accounting for Goodwi11", ARS 10, AICPA, 1968, p. 39. 


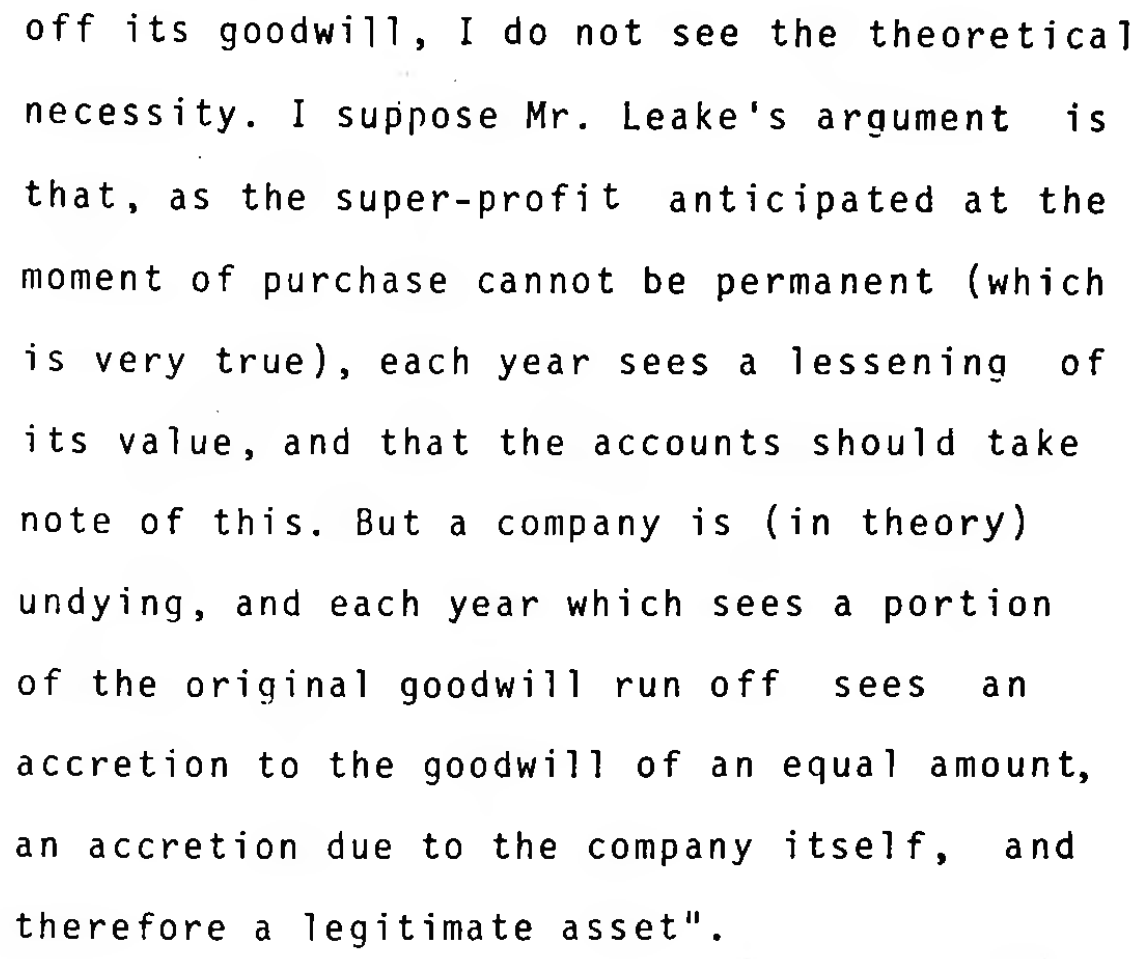

\subsubsection{3, BAIXA IMEDIATA CONTRA O PATRIMONIO LIQUIDO}

E o procedimento defendido por aqueles, dentre os

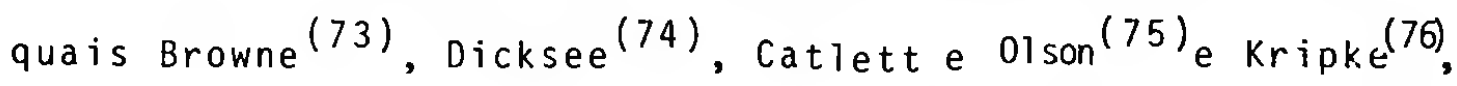
que julgam inadequadas, tanto a manutençäo do goodwill como um ativo sem qualquer alteracão, como tambēm a sua amortiza

(73) Browne, E. A. - "Goodwill: Its Ascertainment and Treatment in Areounts", l'he Aceountint, december/1902,p.1342.

(74) Apud Bryan V. Carsberg - "lhe Contribution of P. D. Leake to the theory of Goodwill Valuation",Journal of Accounting Research, Spring/1966, p. $1 / 15$.

(75) Op.cit. p.78/95.

(76) Apud Fiorge R. Catlett e Norman 0.01son - "Accounting for Goodwill", ARS 10, AICPA, 1968, p. 83. 
cāo para o "matching" com receitas. Essas práticas estariam fundamentadas na crença de que:

a. o goodwill é um ativo cujo valor é suscetivel de mensura cão separada, apōs a sua aquisição, e,

b. o periodo de existéncia do goodwill adquirido pode ser sempre estimado - o goodwill teria uma vida ilimitada ou uma vida limitada estimável.

Os defensores da baixa imediata atacam esses funda mentos, ponderando que:

- em relaç̃o aO ITAM A;

i - o balanco tem por funcão relatar os valores dos recursos separáveis, necessārios a producão de lucros no futuro e não a de mostrar o valor total da empresa ou de todos os fatores e condicöes vantajosas relacionados com ela;

ii. o goodwill é um conjunto de fatores, que não podem ser avaliados separadamente, e está relacionado com a empresa como um todo;

iii. apōs a aquisicão, o goodwill adquirido mistura-se com - não adquirido e deixa de ser um recurso separável, podendo o seu valor ter diminuido ou mesmo sido subs tituido nelo desenvolvido internamente;

iv. os investidores, muitas vezes, ao avaliarem uma empresa, eliminam tanto o valor do goodwill como o da sua respectiva amortizacão;

$v$. apōs uma "combinação de negōcios" a informacão ma is 
relevante quanto a empresa resultante $\bar{e}$ o seu valor expresso em termos de preço de mercado de suas acões, e, a relação preco/lucro;

$v i$. o argumento de que o montante pago a titulo de goodwill precisa ser registrado para uma anālise de retorno mais significativa tambēm não è vālido, pois, se o goodwill deve ser incluido não ē apenas o adquirido, mas o goodwill total da empresa - entretanto, ai, a taxa de retorno deixa de ser uma medida da performan ce do lucro, jā que o goodwill incluido é um valor relacionado com a empresa como um todo.

\section{- em relaç̃̃o AO ITEM B:}

i as próprias caracteristicas do goodwill tornam inde finido o seu periodo de existéncia, a saber:

- valor atribuĩvel a um negōcio como um todo,sem um termo de existência determinado como os outros at $\underline{j}$ vos,

- valor que sofire flutuacões amplas em funcão de inú meros fatores que afetam a capacidade de lucro,

- valor não consumido ou usado na producão de lucros, como o são os recursos separāveis, suas alteracões nao podem ser associadas com receitas de qualquer perîodo;

ii . o valor do goodwill é fortalecido pela ocorrēncia de aumento ou expectativa de aumento nos lucros, consequentemente, não pode ser adequadamente amortizado, 
jā que a amortização implica em consumo de custo na consecução daqueles lucros;

iii. a amortização, mesmo sem evidéncias de diminuição do valor do goodwill, pois a sua constancia ou aumento deve-se ao goodwill não adquirido, acarreta um duplo onus ao resultado, na medida em que os gastos com o goodwill normalmente constituem-se em despesas do exercicio.

Por outro lado, a baixa do goodwill adquirido como reducăo do património liquido teria as seguintes justif $\underline{j}$ cativas:

1. o pagamento pelo goodwill, em ūltima instāncia, seria efetuado pelos acionistas, em função de suas expectativas de excesso de lucros futuros da adquirida - o valor rela tivo ao goodwill pertenceria aos acionistas, sendo uma despesa antecipada pelos lucros futuros e o desembolso deveria reduzir o patrimōnio líquido;

2. a contabilização do goodwill como redução do património liquido estaria reconhecendo a impossibilidade de sepa rar o goodwill adquirido do desenvolvido internamente;

3. permitiria maior comparabilidade nos demonstrativos contābeis das empresas crescidas por aquisicão e por desenvolvimento pröprio, eliminando não só o goodwill como a respectiva amortização;

4. a redução do patrimōnio liqquido refletiria os fatos da transacão (inclusive o fato de que capital com valor determināvel foi utilizado com o objetivo de obter lucros 
futuros), bem como reconheceria a caracterīstica essencial do goodwill de maneira consistente com os objeti vos das demonstraçoes financeiras.

Värias são as formas sugeridas para a realizacão dessa redução do património líquido da empresa sucessora:

a. CONTRA RESERVAS DE CAPITAL OU DE lUCROS - Não haveria justificativa lógica para a preferencia por uma dessas reservas, exceto quando se tratasse de transacão com emissāo de açōes com āgio, pois aî haveria vinculação com reservas de capital. Na prätica, poder-se-ia iniciar com uma das reservas, até o seu esgotamento, e depois prosseguir utilizando a outra. Sands $(77)$ acrescenta que, não sendo suficientes as reservas de capital e de lucros dever-se-ia, em seguida, utilizar o pröprio capital para a realização dessa baixa. Não aparecendo no ba lanço, o goodwill baixado, se não mantido um valor simbölico no ativo (por exemplo $C z \$ 1,00$ ), o "disclosure" poderia ser efetuado em notas no rodapé dos demonstrat vos contábeis. A baixa imediata do goodvill contra reservas de lucros ou de capital foi proibida nos EUA pe10 AICPA, atravēs do "Accounting Research Bulletin" no 53, 1953, embora alguns autores como Catlett e 01 son in sistam na sua defesa. Essa proibiçào fez com que al guns voltassem a defender o lançamento do valor do goodwill contra o resultado do exercício como item ex-

(77) Sands, J.E. - "Wealth, Income, and Intangibles" University of Toronto Press, 1963, pg. 84. 
traordinārio.

b. DEDUCÃO DESTACADA DO PATRIMONNIO LÍQUIDO (conta especĩfica) - Em relação a esse procedimento existem duas corren tes: aqueles que defendem a continuacáo da conta de dedu cão no balanço como custo de ações de tesouraria até que essas ações sejam canceladas, e, aqueles que,como Sanders, Hatfield e Moore ${ }^{(78)}$, defendem a sua manutencio no bala co por alguns periodos, para registro do fato na história da empresa, baixando-se após contra as reservas de capital e de lucros.

A dedução do patrimōnio líquido tornar-se-ia um problema insolūvel, se o valor do goodwill adquirido fosse maior que o patrimōnio líquido da empresa, a não ser que seus defensores não se importassem em relatar um patrimōnio liquido negativo, que poderia nada ter a ver com a realidade.

A imediata baixa do goodwill adquirido contra o pa trimōnio liqquido apoia-se fortemente na conviccão de que ele năo tem relacão com o processo de geração de lucros;tra tando-se inegavelmente de uma forma de livrar-se de uma inconveniēncia e não uma solucão aceitável para a sua contabi lizacao, face os objetivos das demonstracōes financeiras, a necessidade do "disclosure" dos fatos relevantes e da compa rabilidade entre essas demonstrações. Além disso, as mensuracoes das performaces das empresas ficariam distorcidas com a adoção desse procedimento.

(78) Sanders, Thomas Henry, Hatfield, Henry Rand, e Moore, Underhill - "A Statement of Accounting Principles" American Institute of Accountants, 1938 , p. 14. 


\subsubsection{CONSTANTE REVISÃO DO VALOR DO GOODWILL}

Se ē amplamente reconhecida a variação do valor do goodwill adquirido, face aos inúmeros fatores que o inflienciam, e, considerando a inexistēncia de base aceitāvel para a sua amortização gradativa, uma vez que è quase impossivel avaliar a sua durabilidade, a lógica. parece indicar a revisão constante desse valor como procedimento mais correto.

Por outro lado, como apös a transação, o goodwill adquirido e seus efeitos não são mais passíveis de identificação e mensuração separada, o acompanhamento das variações só seria possĩvel mediante a apuração a cada período contábil do valor do goodwill global da empresa, o que incluĩria o goodwill não adquirido.

0 "disclosure" desse valor poderia demonstrar a sua composiçăo, goodwill adquirido e goodwill desenvolvido internamente, ou apenas fazer menção dessa composição em notas explicativas às demonstrações contábeis, pois apōs a aquisição, em realidade, não haveria mais condições de separā-10s.

0 valor do goodwill apurado, descontado o adquirido, teria como contrapartida uma conta reserva de goodwill, integrante do patrimōnio líquido da empresa, que seria aumentada ou diminuida, junto com a conta do atjuo, a cada nova avaliação efetuada. Essa informação seria relevante para os usuārios, jā que estaria relacionada com o valor da 
empresa, medida em termos de sua capacidade de geração de lucros futuros - a variação desse goodwill seria um indica tivo de alterações na capacidade de lucros da entidade. 
CAPITULO IV

PROCEDIMENTOS PROPOSTOS 
4.1. MENSURACÃO DO GOODWILL GLOBAL E AVALIACÕOS CONSTANTES 4.1.1. SITUACÃO IDEAL

\author{
4.1.1.1. ATIVACÃO DE TODOS OS GASTOS RELACIONADOS COM
} GOODWILL PARA TRATAMENTO CONTABIL ADEQUADO

o Goodwill como ainda se apresenta atualmente è um ativo composto pela soma de uma série de fatores de naturezas diferentes, que vão desde a subavaliação de ativos, decorrentes dos métodos de valoracão utilizados, atē a exis tência de ativos importantes não contabilizados,alguns dos quais devido a procedimentos contābeis inadequados.

A não contabilização de alguns recursos como os Recursos Humanos, fator de importāncia fundamental na consecucăo de lucros empresariais, tem como principal argumen to a sua não caracterização como um ativo, no sentido legal, de posse. Entretanto, a forca de trabalho existente em uma empresa tem, normalmente, um vinculo contratual, estabelecendo direitos e obrigações das partes, alguns dos qua is jā são contabilizados (por. exemplo: FGTS), o que poderia fornecer uma justificativa para a sua contabilização, contanto que a Contabilidade não se apegasse demasiadamente ao fundamento legal na caracterizaça de ativos.

Por outro lado, com o desenvolvimento sucessivo de modelos estatisticos de avaliacão do valor de recursos humanos certamente remover-se-à outro obstáculo alegado para 
a não contabilização: dificuldade de mensuração do seu valor. A determinacão de sua vida ütil para efeito de depreciacăo aparentemente não è muito mais problemātica que a de qualquer outro ativo, podendo ter por base o prazo médio de permanência de um empregado na firma, com diferen ciacão por grupos de trabalhadores, ou o periodo de tempo até a sua aposentadoria, se a rotatividade de mão-de-obra for insignificante.

Uma mensuração adequada do goodwill de uma empresa, como já foi visto no capitulo II, requeriria o "expurgo" do seu valor de tudo que não correspondesse efetivamente ao goodwill, não sō pela identificação e mensuração individua lizada de todos esses ativos ocultos passiveis de tal tratamento, como também pelos procedimentos contábeis adequados relativamente a gastos com Pesquisa e Desenvolvimento ( $P$ \& D) e Propaganda e Publicidade ( $\&$ P)atualmente considera dos como despesas do exercỉcio em que são incorridos. Ambos deveriam ser classificados como Ativos Diferidos, sendo que, no caso especifico de $P$ \& $D$, na medida em que os sucessos fossem se verificando, aqueles gastos seriam apro priados como custos de patentes, förnulas, e processos descobertos, para amortizacão dentro do prazo de suas vidas üteis.

Relativamente aos gastos com Propaganda e Public dade, o ideal seria a possibilidade de separar seus efeitos. para uma contabilização mais adequada - por exemplo, quando propagandas institucionais $\vec{e}$ de se esperar que uma parte dos seus efeitos tivessem carāter mais duradouro, fortale- 
cendo a marca ou o nome da empresa, enquanto a outra um ca räter mais efêmero, refletindo-se nas receitas por um periodo de tempo limitado, portanto, a parcela dos gastos correspondente estaria sujeita a amortizacäo dentro desse prazo.

Enfim, todos os fatores que influem na capacidade de lucro de uma empresa deveriam ser registrados pela Contabilidade, de forma que o resultado de uma entidade fosse atribuivel apenas aos recursos contabilizados.

Ao contrário do que hoje ocorre, com tendéncias de agravamento das distorcões, na medida em que as empresas se sofisticam, a adoção dos procedimentos contábeis mencio nados reduziriam o goodwill a sua correta dimensão, sem inclusão no seu valor de parcelas atribuiveis a outros recur sos ou fatores de lucro.

4.1.1.2. AVALIACAOO DOS VALORES ECONÓMICOS INDIVIDUAIS DE TODOS OS ATIVOS (INCLUSIVE OS NÃO CONTABILIZADOS ATUALMENTE )

Essa avaliação corresponderia a maior soma entre Lucros Liquidos anuais acumulados atribuiveis a cada ativo, e o seu valor líquido de realizacão no final de cada perío do, ambos descontados pela taxa de remuneracão de empreendimento de igual risco.

Como foi visto no capitulo 3 , assim seria repre sentado algebricamente o valor económico de um ativo: 


$$
A_{i}=\frac{v_{t}}{(1+j)^{t}}+\sum_{t=1}^{m} \frac{R_{t}}{(1+j)^{t}}
$$

onde: $A_{j} \ldots .$. Valor económico de um ativo;

$$
\begin{aligned}
& v_{t} \ldots . . \text { Valor líquido da realizacão no final do } \\
& \text { periodo } t \text {; } \\
& \text { j..... Taxa de desconto (custo de oportunidade) } \\
& \text { correspondente a remuneracão de empreen- } \\
& \text { dimento de igual risco; } \\
& m \text {..... Periodo em que a soma de } v_{t} \text { e } R_{t} \text {, des - }
\end{aligned}
$$

A formulação acima, no entanto, requeriria um ajus te, pois, caso contrário, a mesma falha atribuída aos outros métodos - a de não apurar o valor real do goodwill ocorreria tambēm na sua aplicacão. E nesse caso, poderia até redundar na distribuicão do valor do goodwill pelos de mais ativos, ocasionando as suas superavaliacōes. A solução do problema seria considerar $R_{t}$ o resultado económico normal produzido por um ativo similar ou igual no periodo $t$.

Se maior precisão fosse requerida, os descontos dos resultados econōmicos deveriam também levar em conside ração os momentos em que esses resultados ocorreram no decorrer de cada período - caso normalmente distribuídos em cada periodo, poder-se-ia aplicar, como aproximação, a taxa 
relativa ao meio de cada período.

Por outro lado os valores económicos de ativos co mo caixa e bancos correspondem ao seu próprio valor na data da avaliacão, enquanto os ativos realizáveis devem ser avaliados de acordo com os seus valores liquidos de realização, descontados, levando-se em conta a possível data de venda.

\subsubsection{APURAČ̃O DO GOODWILL SINERGISTICO E AVALIAC̄ÕES CONSTANTES}

Efetuada a apuração do valor econōmico do ativo,o do passivo equivaleria ao seu valor de liquidacão na data da avaliaçăo, com computação de eventuais descontos obten veis. Obtido o Patrimōnio Líquido em valores econōmicos e tendo-se em mãos os lucros futuros projetados da empresa,o goodwill sinergistico poderia ser expresso como segue:.

$$
G=\sum_{t=1}^{n} \frac{L L_{t}-P L E_{t}}{(1+j)^{t}}
$$

onde: $L L_{t} \ldots$ Lucro Liquido no período $t$;

$$
\begin{aligned}
P_{t} \ldots . . . & \text { Património Liquido em valores económicos } \\
& \text { no final do periodo } t ; \\
j \ldots & \text { Taxa de desconto (custo de oportunidade) } \\
& \text { correspondente a remuneracão de empreen- } \\
& \text { dimento de igual risco. }
\end{aligned}
$$

Para uma mensuração mais precisa desse goodwill se ria ideal ainda "expurgar" do seu valor os efeitos de va- 
riacões conjunturais atīpicas, favoráveis ou desfavoraveis, por independerem da acão da empresa. 0 goodwill resultante seria atribuivel exclusivamente a sinergia organizacional da empresa, um valor muito mais significativo porque relativo à prōpria essência da eficiência da empresa em combinar os recursos escassos administrados (79).

(79) O goodwill sinergistico apurado pela aplicaço dessa Eórmula poderia ser igual ao goodwill dos super-lucros abaixo:

$$
G=\sum_{t=1}^{n} \frac{L L_{t}-r P L_{t-1}}{(1+j)^{t}}
$$

onde: LLt ..... Lucro Liquido no periodo $t$;

r ...... Taxa normal de retorno sobre o Patrimōnio liquido;

PI. ..... Patrimoño líquido pelo valor líquido de reializaciäo;

j ..... Taxa de desconto (custo de oportunidade) correspondente à remuneração de empreendi mento de igual risco.

se $r=\mathrm{PLE}_{t} / \mathrm{PL}_{\mathrm{t}-1}$ pois, para:

$$
\begin{aligned}
\sum_{t=1}^{n} \frac{L L_{t}-P L E_{t}}{(1+j)^{t}} & =\sum_{t=1}^{n} \frac{L_{L}-r P L_{t-1}}{(1+j)^{t}} \\
P L E_{t} & =r P L_{t-1} \\
r & =\frac{P L E_{t}}{P L_{t-1}}
\end{aligned}
$$


A sua avaliacão a cada periodo forneceria elementos mais úteis relativos ao comportamento organizacional, a pontando as variacões da sinergia de período a período,para a verificação das suas possiveis causas - a anālise com parativa com as situacões de outras empresas seria tambēm de grande validade para eliminacão de eventuais deficiên cias.

4.1.2. TRATAMENTO CONTÁBIL IDEAL

0 goodwill sinergístico global, apurado em 4.1.1.3, seria contabilizado como um ativo intangivel, destacado no Ativo Permanente, tendo como contrapartida, no Património Liquido, Reserva Especial de Goodwill, uma conta de nature za e função semelhante a antiga conta Reserva de Correção Monetāria.

Ocorrendo aquisicão de outra empresa com goodwill sinergistico, o valor deste seria destacado na Contabilida de, por tratar-se de transacão sem contrapartida em Reserva Especial de Goodwill, de forma que na avaliacão do goodwill sinergistico global da empresa, a diferenca apurada seria lançada contra o Goodwill Sinergístico não Adquirido e a Reserva Especial de Goodwill. Um procedimento contábil alternativo seria lançar esse goodwill sinergistico adquirido como deducão da Reserva de Capital ou de Lucros, para a sua evidenciação, e, no exercĩcio subsequente, baixa-lo con tra a referida conta, pois o seu valor estaria incluido no Goodwill Sinergistico Global. 
A avaliação e contabilização do goodwill independentemente de qualquer transacão evitaria as distorcões de correntes de tratamentos desiguais para situacões similares (goodwill adquirido $x$ goodwill não adquirido, purchase $x$ pooling), como jā foi abordado, ao mesmo tempo em que a $\underline{u}$ mentaria os padrões de comparabilidade dos demonstrativos contābeis.

As contas Goodwill Sinergistico e Reserva Especial de Goodwill sofreriam ajustamentos anuais de acordo com os resultados das reavaliacões anuais $(80)$ do goodwill da empresa.

O Balanço Patrimonial em valores económicos, evidenciando em cada perĩodo o valor da empresa e o grau de sinergia existente entre os seus elementos patrimoniais,e, efetuando ainda um "disclosure" completo e real da situa cão da empresa e do seu potencial futuro, seria de grande utilidade para os usuärios. Esse Balanço Patrimonial, que poderia ser chamado de "Balanco Preditivo", seria apresentado paralelamente ao convencional, com o "disclosure" de todos os dados utilizados para a sua elaboracão, bem como das probabilidades estatisticas envolvidas, para permitir aos usuārios as adaptacões cabỉveis aos seus modelos de de cisão.

(80) Reavaliaçào é aqui uitlizada no sentido amplo que o termo configura normalmente, significando nova avalia çào, portanto, não implicando obrigatoriamente em ajus tes para cima. 
0 Resultado Econômico poderia ser obtido pela diferença entre os Patrimônios Líquidos do final e do inîcio do periodo, excluindo-se os aumentos de capital com novos recursos dos sōcios/acionistas e adicionando-se os lucros/ dividendos distribuidos no periodo. A Demonstracão de Resultados Económicos correspondente poderia ser elaborada pela conciliação com a Demonstracão de Resultados Conven cional, evidenciando-se os lucros ainda não realizados e, portanto, ainda não passiveis de distribuicão aos sōcios / acionistas.

0 tratamento contábil ideal eliminaria muitas criticas que são normalmente feitas aos procedimentos contābeis vigentes, especialmente aquelas relacionadas com a irrealidade das demonstrações e dos resultados contābeis apresentados, que diminuiria a sua utilidade como fonte informativa para a tomada de decisões.

\subsection{PROCEDIMENTOS IDEAIS $X$ PROCEDIMENTOS PROPOSTOS}

\subsubsection{IMPRATICABILIDADE DOS PROCEDIMENTOS IDEAIS}
4.2.1.1. EM FUNÇÃO DA NÃO CONTABILIZAÇ̃O COMO ATIVOS DE AL GUNS FATORES DE LUCRO

Embora em relacão a gastos com P \& D e Propaganda e Publicidade jā existam bases mais seguras para as suas ativacões e uma razoável aceitacão desse procedimento, fato res de lucro como. Recursos Humanos, talvez os recursos pro dutivos mais importantes de uma empresa e, não obstante,ser imprescindivel o "disclosure" do "seu valor aos usuārios, o 
atingimento de igual estāgio dependerā da remoção de alguns obstāculos como a definicão da sua mensuração mais adequada e do fundamento para caracterizaça de ativos.

Um fato positivo para o reconhecimento e contabil $\underline{\mathbf{j}}$ zação, no futuro, de todos os fatores/recursos responsáveis pelo desempenho de uma entidade, é a consciência do meio contābil de que essa é a situacão ideal, bem como o número crescente de estudiosos que buscam o seu atingimento, promo vendo o desenvolvimento da Ciēncia Contābil.

4.2.1.2. FACE A IMPOSSIBILIDADE DE OBTENÇÃO DO VALOR ECONÓMICO INDIVIDUAL DE CADA ATIVO

Pode-se afirmar que nenhum ativo isoladamente tem condições de produzir resultados económicos, já que a produ cão é sempre uma resultante da combinacão de ativos. Como então avaliar a participação individual de cada ativo nos resultados económicos obtidos?

Trata-se de uma pergunta que dificilmente terā uma resposta convincente, pois, qualquer que fosse o método uti lizado para essa avaliação individual, a consequência seria sempre a atribuicão arbitrāria de valores econōmicos aos ativos individuais, distorcendo os valores dos elementos pa trimoniais no balanco da entidade.

Por outro lado, mesmo admitindo-se a possibilidade da mensuracão do valor econōmico individual de cada ativo, haveria ainda o problema relacionado com o fato de que, con forme a forma de apuração desse valor,a idénticos ativos poderiam 
ser atribuidos valores econōmicos completamente diferentes, pois eles jä trariam embutidos uma parcela do valor atri buivel ao goodwill sinergistico da entidade. Teoricamente, a solucão seria a atribuicão de valor econômico normal a cada ativo, como abordado no capitulo III, jā que somente as sim sobraria um valor reivindicável para a sinergia organi zacional da empresa.

Entretanto, surge a questão: o que poderia ser considerado como valor econômico normal, a média do ramo de atividade da empresa?

Em verdade, na avaliação de um ativo de producão, esse problema tem dois aspectos a analisar, tendo em vista a förmula do capitulo III ${ }^{(81)}$ :

a. Receitas Normais - teriam que corresponder a quantida des normais a precos normais, pois qualquer excesso tanto na quantidade quanto nos precos poderiam ser atri buiveis a outros fatores como a maior eficiencia da mãode-obra da empresa ou a sua localizacão privilegiada em relação aos clientes.

b. Valor Lĩquido de Realizacão Normal - levaria em conside ração um prazo de venda não forcada e um valor normal de realização.

Os problemas inicialmente apontados, ainda sem so lucão, somados aos acima mencionados, aumentam sensivelmen

(81) Trata-se da förmula para avaliação do valor economico individual de ativo:

$$
A_{i}=\frac{v_{t}}{(1+j)^{t}}+\sum_{t=1}^{n} \frac{R_{t}}{(1+j)^{t}}
$$


te o grau de subjetividade da mensuracão do valor económico individual dos ativos, tornando pouco confiāvel seus re sultados. Dessa forma, apesar dos esforcos no sentido da sua mensuração mais adequada, a grande maioria dos estudio sos tem optado por mensurações alternativas objetivando re sultados aproximados.

4.2.2. MÉTODOS DISPONIVEIS PARA MENSURAÇÃO DO GOODWIL 4.2.2.1. ANALISE CRITICA DOS MÉTODOS EXISTENTES

a. IMPRATICABILIDADE DO MÉTODO IDEAL - Como foi visto em 3.1 .2 e 4.2.1. a contabilização de todos os fatores respon sāveis pelo sucesso de uma empresa, bem como a avaliaça de seu valor econômico individual, não é passivel de reali zação sem a incorrência em um alto grau de subjetividade e alocações altamente arbitrārias. Em sua jā citada tese de doutoramento, o professor Dr. Eliseu Martins, admitidas as hipóteses de lucros e taxas de desconto constantes e perenidade da empresa, chega à seguinte expressão para o valor econōmico do Ativo, partindo do cālculo de limite da fun cão descontinua $A=\sum_{t=1}^{n} \frac{Y}{(1+r)^{t}}$ para $t \rightarrow \infty$ ou da integração da função contīnua $A=\frac{y}{e^{r t}} \quad(80-a)$ :

$$
\text { Ativo Total }=\frac{Y}{r}
$$

onde: $Y$.... Lucro Liquido supostamente representativo do resultado econômico;

$r$.... Taxa de desconto correspondente ao lucro normal.

(80-a) Op. cit.p. $97 / 98$. 
Alēm das hipōteses por demais simplificativas da realidade dos negōcios, a sua utilização só possibilitaria a apura cão do valor do Ativo Total, incluindo goodwill, sem individualizacão da contribuicão dos ativos individuais. Cons derando que, para a tomada de decisões, $\bar{e}$ importante o conhecimento da contribuicão individual de cada ativo no desempenho da entidade, a solução, portanto, leva à utilizacão de mētodos alternativos que possam constituir-se em aproximações (substitutos) do valor econōmico de um ativo e da renda econōmica.

b. OBJETIVIDADE E COMPARABILIDADE - Segundo James E. Parker (81), objetividade é frequentemente interpretada como "existente fora da mente" ou "tendo uma existēncia sepa rada e independente" e aduz:

"From this viewpoint, objectivity refers to an external reality that is independent of the person who perceives it. Unfortunately, this concept of independent existence has led some to equate objectivity with verifiability since a necessary condition of verifiability is the existence of the evidence. One gets the impression that makes the measure itself

(81) Parker, James E. - "Testing Comparability and Objectivity of Exit Value Accounting" - The Accounting Review vol. 50, 1975 - p. $513 / 514$. 


\begin{abstract}
verifiable and hence objective... If the measurement rules in a valuation system are specified in detail, one would expect the output (valuation amounts) of the system to show little deviation from measurer to measurer. Thus, the extent of objectivity of a valuation system can be conceived of as the degree of consensus in its output". (grifo deste).
\end{abstract}

Objetividade, assim, seria um conceito intra-ativo ("intra-active concept"), desde que relacionado com o consenso entre contadores na mensuração do seu valor, enquanto Comparabilidade seria um conceito inter-ativos ("inter active concept"), importante na tomada de decisões económicas que envolvessem comparação entre alternativas disponĩ veis - os dados contābeis seriam essenciais para a realização dessa comparação entre períodos e entre empresas. 0 tomador de decisões estaria mesmo interessado nas características económicas reais ou subjacentes dos ativos, das qua is as mensuracões contābeis são aproximaçōes (substitutas). Ha veria comparabilidade somente se objetos e eventos com ca racterísticas económicas similares fossem contemplados com mensurações contābeis similares.

Uitilizando os conceitos expostos e a técnica esta tística da anālise da variância, Parker testou o método de avaliação de ativos pelo valor de saída, em confronto com o custo histórico, considerado, em geral, como o método que apresenta a mais objetiva das mensuraçōes, e, concluiu que: 
- os valores de saida apresentavam maior comparabilidade que os custos histōricos;

- os valores de saida eram mais objetivos que os custos his tōricos.

Igualmente, D. L. Mc Donald ${ }^{(82)}$ concluiu em estudo de natureza semelhante que:

\begin{abstract}
"The empirical data reported for automobiles provide evidence that direct reference to available market price indicators results in less disperse measures than those now obtained under Generally Accepted Accounting Principles".
\end{abstract}

Os Custos Históricos, na verdade, só seriam realmente objetivos e comparāveis, se ativos iguais tivessem o mesmo valor independentemente do tempo e das empresas que os possuissem, considerando que os seus potenciais de serviços seriam iguais - não é essa, no entanto, a realidade que se constata.

Mesmo que não se aceite integralmente as conclusões de Parker, fica demonstrado que objetividade e Compabilidade, conceitos dos mais importantes na teoria contábil, podem ser interpretados de forma muito mais significa tiva que a tradicional, utilizando dados publicados e tecnicas estatisticas.

(82) McDonald, D.L. - "A Test Application of Feasibility of Market Based Measures, in Accounting" - Journal of Accounting Research - vol. 3. no 1, 1968 - p. 49. 
c. INADEQUAÇAOO DO CUSTO HISTÓRICO E DO CUSTO HISTÓRICO COR RIGIDO - Em 3.2.?, foi abordada a irreleväncia das men surações pelo Custo Histórico num ambiente de variação de preços, não só aquela decorrente da inflação, que deteriora a unidade padrão de medida, como também aquela específi ca de um determinado bem ou ramo de atividade. os lucros apurados pelo Custo Histórico não refletem a reàlidade ope racional da empresa, ficando super-avaliados pela não computação dos aumentos nos custos, o que pode acarretar dec $\underline{\mathbf{j}}$ sões desastrosas para o prosseguimento das atividades no futuro. Ainda a propósito dos Custos Histōricos,assim se pronunciou Bernstein.(83):

"Only by sheer coincidence can historical costs be useful to analysts. They are not relevant to questions of current replacement or of future needs. They are not directly comparable to similar data in other companies reports. They do not enable us to measure the opportunity cost of disposal and alternative use of funds, nor do they provide a valid yardstick against which to measure return. Moreover, in times of changing price levels they represent an odd conglomeration of variety of purchasing power disbursements" (grifo deste).

(83) Bernstein, Leopold A. - "Financial Statement Analysis Theory,Application and Interpretation" Rev. Edition - Richard $D^{\circ}$. Irwin, Inc. - Homewood, Illinois, 1978 - p. 153. 
Jā o Custo Histōrico Corrigido pelo Indice Geral de Precos (IGP) promove ao ajustamento dos Demonstrativos Contābeis ao Custo Histörico, eliminando os efeitos distorcivos da variação do poder aquisitivo da unidade padrăo de medida. E facilmente aplicāvel, pois, alēm de partir das Demonstracões Contābeis ao Custo Histōrico, o Indice Geral de Preços é um dado disponĩvel a quaiquer empre sa. Entretanto, a variação de preços de um determinado bem pode ser superior ou inferior aos indices gerais de precos, e, se isso ocorrer, o Método do Custo Histōrico Corrigido pelo IGP, ao invés de eliminar, estarā acrescentando uma outra distorcão nas Demonstrações Contābeis. As variações especificas de precos, muito mais comuns, são amplamente re conhecidas como mais relevantes para as mensuraçōes contābeis, que aquelas decorrentes apenas de alteracões no poder aquisitivo da moeda, como o afirma o Prof. Dr. Sérgio de Iudícibus $(84)$ :

"... Mais importantes são as flutuacões es-

pecíficas de preços de bens e servicos, i.é,

a apuracão de valores correntes".

Portanto, os métodos de avaliação de valores cor rentes, de acordo com a maioria dos estudiosos, proveem mensuracões contābeis mais significativas que o tradicional Custo Histōrico ou mesmo o Custo Histōrico Corrigido pelo IGP.

(84) Iudicibus, Sergio de - "Contribuição a Teoria dos Ajustamentos Contabeis" - Tese de Doutoramento apresen ta na FEA-USP, em 1966 p.119. 
d. VALORES CORRENTES - Estes podem referir-se a valores de entrada (Custos Correntes ou de Reposicão) ou de saida(Valores de Realização) ${ }^{(85)}$, ambos reclamados pelos seus defensores como aproximações (substitutos) das mensurações do valor económico. No entanto, como foi amplamente abordado em 3.1.2, ambos os métodos têm as suas vantagens e desvantangens - uma anālise crỉtica de alguns pontos principais serā apresentada abaixo:

1. o Valor de Realização do Ativo estaria mais próximo de seu valor econômico, se todos os ativos possuidos tives sem, individualmente alta liquidez, i.ē, fossem passí veis de venda a qualquer momento, sem dificuldade, por um preço coerente com o seu potencial de serviços res tante. Ao contrārio, na prātica, a situação é bem diver sa, e, um ativo antigo, fora de moda, pode ter valor de realizacão até nulo, embora possa possuir um poten cial de serviços igual a de um novo.

2. Ativos Diferidos como despesas prē-operacionais tem valores de realização nulos, embora possam representar fa tor contributivo aos resultados operacionais da empresa.

3. Produtos Destinados à Venda são ma is coerente e objetivamente avaliäveis pelos seus valores correntes de saida, de fácil obtencão, que pelos seus valores de repo-

(85) Os valores de saida podem corresponder a Valores Espe rados de Realizaça ou Valores de Oportunidade (custo de oportunidade), porém ambos se revestem de alto grau de subjetividade. 
sição de cada fator empregado na produção, resultando em mensurações mais trabaihosas e menos objetivas;

4. Custos de Reposicão de Ativos Usados sempre são problemä ticos, pois, mesmo que se defina a reposicão em termos de igual potencial de servicos, os ativos adquiridos, se não forem iguais aos possuidos, podem alterar a estrutú ra de custos da empresa (aumento do valor da depreciacão e diminuição do custo de mão-de-obra). Para ativos especĩficos, construidos sob especificacão individual e jā não mais fabricados, face às mudancas tecnológicas, são basicamente duas as formas propostas para a apura cão do seu custo de reposicão:

a. laudo de avaliação, e

b. o uso de números indices específicos para ajustar a base de custo original ao montante que teria de ser pago correntemente por tais ativos.

Efetuando-se uma rápida anāi ise comparativa des ses métodos, pode-se concluir que, relativamente aos atidestinados à venda, os Valores de Realização são as melhores medidas dos Valores Econōmicos desses ativos, enquanto em relação aos ativos permanentes, especialmente equeles bem especĩficos, os Custos de Reposicão geralmente aproximam-se mais dos seus Valores Económicos pois seus valores de realização podem ser menores atē que seus custos histōricos.

Embora Stephen A. Zeff ${ }^{(86)}$ tambēm jä aceite os Cus

(86) Zeff, Stephen A. - Replacement Cost: Member of the Family, Welcome Guest, or Intruder" - The Accounting Review - Vol. 37,1962 - p. 623. 
tos de Reposicão como uma aproximacão dos Valores Econōmi$\cos :$

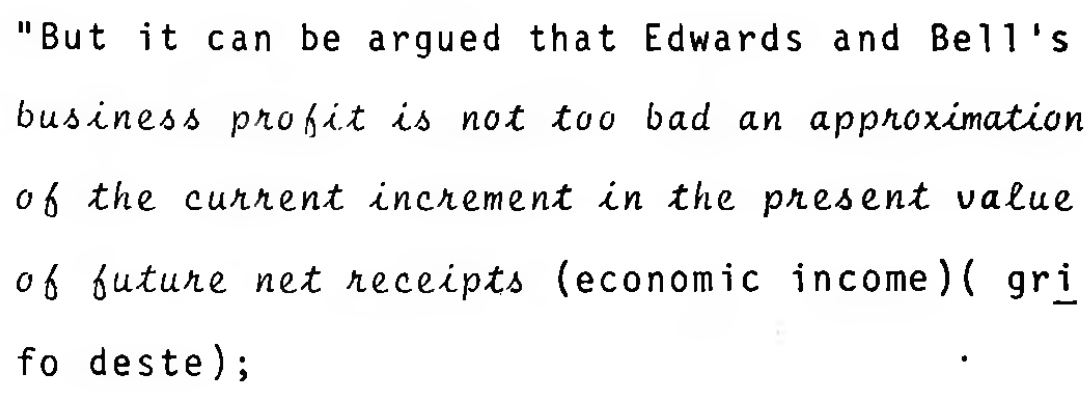

- mesmo ocorrendo com Donald A. Corbin (87):

"Given a satisfactory degree of competition, the prices of assets in the market prices would serve as objective, indirect estimates of value..." (grifo deste);

e Edgar 0. Edwards ${ }^{(88)}$ não se oponha a avaliação de ativos pelo preço de venda:

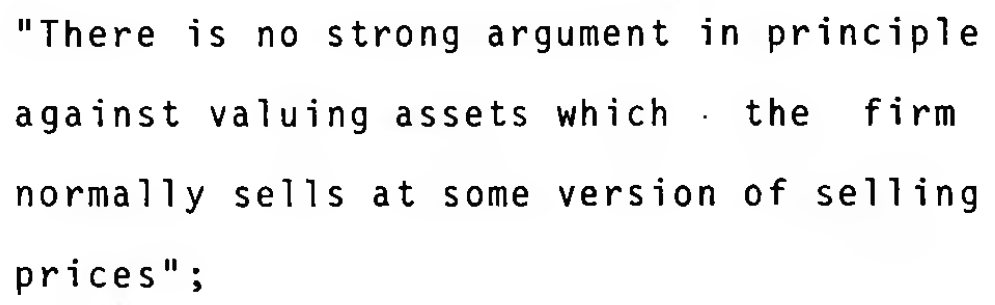

a melhor aproximacão do Valor Economico do Ativo indica cla ramente a necessidade de utilização de um método misto, envolvendo avaliacões de ativos pelos Valores de Saida e pelos Custos de Reposição.

A coerēncia da "mesclagem" de dois mētodos de ava-

(87) Corbin, Donald A. - "The Revolution in Accounting"- The Accounting Review - vo1. 37, 1962 - p. 630.

(88) Edwards, Edgar 0. - "The State of Current Value Accounting" - The Accounting Review - vol. 50,1975 - p. 241 . 
liacão é justificada pelos próprios procedimentos contábeis pelo Método do Custo Histórico,produtos da aplicacão de um método misto, na medida em que se estabelece a regra "Custo ou Mercado, O Mais Baixo".

A Lei das Sociedades por Ações, Lei nọ 6.404/76, em seu artigo 183, $\S 10$, letras a e $c$, estabelece como valor de mercado:

- matérias primas e bens de almoxarifado - o preco pelo qual possam ser repostos, mediante compra no mercado;

- bens ou direitos destinados à venda - o preco liquido de realizacão, mediante venda no mercado, deduzidos os impos tos e demais despesas necessārios para a venda e a margem de lucro;

- investimentos - o valor liquido pelo qual possam ser alie nados a terceiros.

A definicão dos critérios de atribuicão de valor, acima apresentada, distingue claramente a situacão da empre sa em relação ao mercado. Assim, no caso de matérias primas, a relação normal da empresa com o mercado é a de comprador, e, consequentemente, elas são avaliadas pelos seus Custos de Reposicão, mas apenas quando inferiores ao Custo Histör co registrado. Analogamente, sendo a relacão empresa-mercado, a de vendedora para os produtos/mercadorias destinadas à venda, suas avaliacões terão por base os Valores de Realiza cão, se menores que o Custo Histōrico registrado.

0 Método de Avaliação Misto, que será denominado simplesmente de Método de Valores Correntes, poderia basear 
seus critérios de avaliação de ativos na relacão empresa mercado acima abordada, de forma que todos os ativos da em presa seriam avaliados pelo seu Custo de Reposicão ou pelo Valor de Realização, resultando uma maior aproximação do Valor Econōmico do Ativo.

Por outro lado, a utilização de critérios mistos tem sido proposta por alguns autores como Y. Goldschimidt e S. Smidt(89):

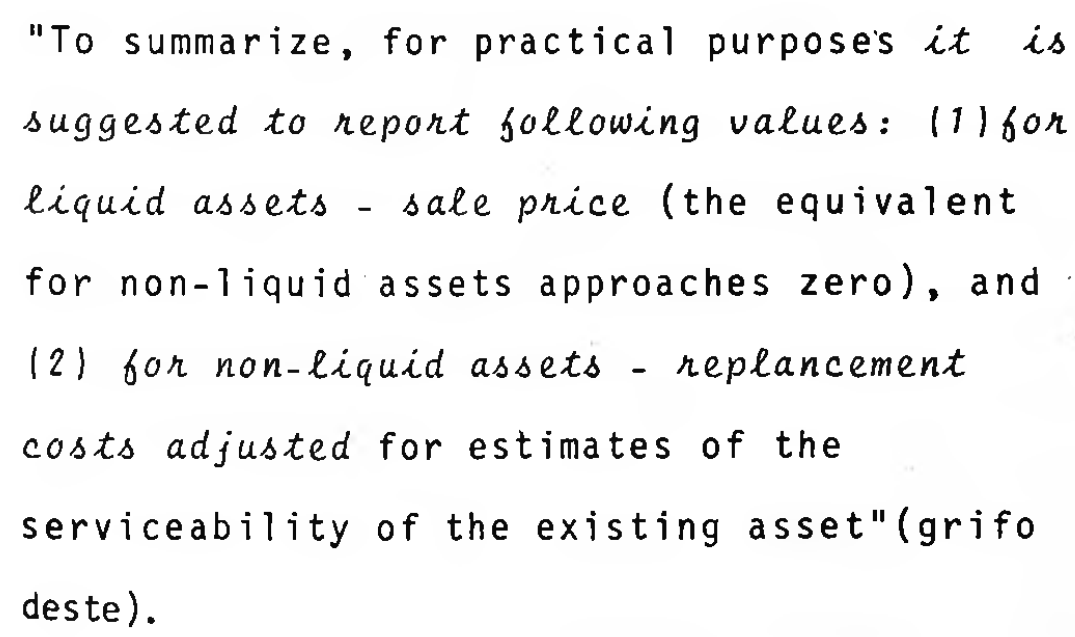

Justificada plenamente a uitlização do Método de Valores Correntes do ponto de vista metodológico, resta analisar os resultados de suas mensuracões sob a ótica da Relevāncia e Comparabilidade. Tratando-se de método, cuja regra bãsica de mensuração leva em consideracão a relacão empresa-mercado, os resultados dessa mensuração certamente serão mais relevantes que aqueles obtidos por outros méto dos, pois constituem-se em valores correntes. de mercado.Sob

(89) Goldschimidt, Y. e Smidt, S. - "Valuing Firm's Durable Assets for Managerial Information" - The Accounting Review - vol. 44,1969, p. 322 . 
- aspecto da Comparabilidade de suas mensuracões, jā se pró nunciaram os autores anteriormentes citados, demonstrando a existência de uma dispersão menor de seus valores relativamente aqueles obtidos pelos Custos Histōricos.

As Demonstracões Contābeis baseadas no Método de Valores Correntes serão muito mais üteis aos usuārios não sō por apresentarem uma situação mais real da empresa, mas tambëm por possibilitar a avaliacão do seu potencial de lucro a Curto Prazo, tendo em vista especialmente a distribui cão de dividendos.

\subsubsection{DETALHAMENTO DO MÉTODO DE AVALIAÇÃO ADOTADO}

Relativamente a ativos como matérias primas, bens de almoxarifado, bens ou direitos destinados à venda e ou tros a eles assemelhados, as suas avaliacões serão efetua das de acordo com os seus valores de mercado, na forma pres crita no artigo 183, da Lei das Sociedades por Acões.

Ativos como Caixa e Bañcos não apresentam qualquer problema de avaliação, enquanto Valores a Receber serão ava liados pelo valor do seu saldo na data da avaliacão, deduzi do para provisão para perdas estimadas.

A avaliacão dos produtos em processo poderá ser efetuada com base, inicialmente, na apuracão das "unidades equivalentes de produtos acabados", aplicando-se em seguida as mesmas rearas de valoração de "unidades de produtos acabados", podendo ser descontados do valor do produto acabado os custos necessārios para para com- 
pletar o processo produtivo.

Enfim, todo o Ativo e tambēm o Passivo teriam como critério básico para a sua avaliação o Custo de Reposição ou - Valor de Realização, conforme a posicão normal da empresa em relação ao mercado: compradora ou vendedora.

\subsection{PROCEDIMENTOS PROPOSTOS}

4.3.1. APURAÇ̃̃O DO GOODWILL GLOBAL UTILIZANDO MÉTODO DE VAL-O RES CORRENTES

4.3.1.1. JUSTIFICATIVAS PARA CONTABILIZAÇÃO DO GOODWILL GLO BAL

Conforme jā foi abordade em 3.2.2., o não reconhecimento do goodwill não adquirido prejudica o tratamento con tábil mais adequado do goodwill adquirido, assim como tor nam não comparáveis empresas similares, quando uma o adquire e a outra o desenvolve internamente. As Demonstracões Con tábeis ilustrativas, ali apresentadas, mostram as distor cões provocadas nos resultados e situacões patrimoniais da empresa, que poderiam induzir usuārios a anālises e deci sões completamente equivocadas. A solucão do problema da existēncia de fatores de lucro não contabilizados, verdade ros ativos ocultos, que prejucicam a comparabilidade das De monstracões Contäbeis das empresas, poderia ser encaminhada em dois sentidos:

1) agrupando os fatores de lucro não contabilizados individualmente sob o título "goodwill" (ativo intangivel), e, 
ao mesmo tempo;

2) aumentando gradativamente o nūmero de fatores de iucro contemplados pela contabilidade, o que requeriria uma reformulacão dos Principios e Convencões Contábeis Geral mente Aceitos, mas principalmente uma postura mais desen volvimentista dos profissionais da Contabilidade.

Nos casos especificos de empresas comerciais ou prestadores de servicos, a não contabilizacão do goodwill tor naria ainda menos comparáveis as suas Demonstrações Contā beis, uma vez que seus fatores mais importantes, localiza cão e recursos humanos, não estariam incluídos em seus re gistros contābeis.

William A. Paton $(90)$ assim se pronunciou sobre a a subavaliaça o ocultamento de ativos:

"Understatement and concealment of assets is an old story dating back to the days when hiding valuables from the eyes of the tax collectors was conventional conduct. Most of the works on auditing and accounting over the past half-century continue to cater to understatement, especially by overemphasizing the significance of recorded costs. In most books the reader is warned about the need for vigilance in preventing padding and overstatement, but virtually nothing is said

(90) Paton, William A. - "Comments on Accounting for Goodwill" in Catlett, George R. e 01 son, Norman "Accounting for Goodwill", ARS n? 10,1968 - p. 148. 
about understatement, which actually the important problem. The point of these comments connection lies in the undesirebility of giving encouragement at this juncture to the understatement of business resources, tangible or intangble. It is the job of accounting to disclose significant financial measurements, not to cover up"... (grifo deste).

Por outro lado, quase toda a discussão em torno do melhor procedimento em relação ao goodwill adquirido, acaba desembocando no reconhecimento tácito de que o goodwill não adquirido jamais poderia ser ignorado. Segundo catlett e 01 son (91), autores de um dos estudos mais abrangentes sobre a contabilizacão do goodwill, se um negōcio possui goodwill, a suas características, adquirido ou não, não proveem bases para abordagens completamente diferentes, como atualmente existentes. Acrescentam ainda que, apōs a aqui sicão, o goodwill adquirido confunde-se com o não adquirido, passando a existir apenas um ūnico goodwill, o goodwill da empresa.

Ante a situacão exposta, por que não mensurar e con tabilizar o goodwill global da empresa, incluindo o goodwill adquirido e o não adquirido, ao invēs de insistir na busca inútil do tratamento contābil ideal apenas para o goodwill não adquirido?

(91) op. cit. p. 69 . 
0 "disclosure" do goodwill global nas Demonstra cões Contābeis, além de estabelecer a comparabilidade entre as empresas similares, com goodwill adquirido ou não, seria uma informacão altamente relevante para os usuārios, especialmente os externos, na medida em que o valor desse goodwill relaciona-se com as perspectivas de lucros de acordo com a prōpria administração da empresa.

\subsubsection{GOODWILL GLOBAL PELO MÉTODO ADOTADO}

Mesmo com a adequação do procedimento contābil ré lativamente a gastos com Pesquisa/Desenvolvimento e Propaganda/Publicidade, i. é, com a ativacão deles para o cus teamento das descobertas ( $P \& D)$ e diferimento para amort $\underline{i}$ zação ( $P$ \& $P)$, a não contabilização de outros fatores importantes e a impraticabilidade da mensuracão do valor eco nōmico individual dos ativos impossibilitam a avaliacão do desejāvel valor do goodwill sinergístico.

o goodwill global apurado, pelos motivos expostos, ainda estaria longe de representar a sinergia organizacional da empresa, razão porque não terā essa pretensão, sendo denominado simplesmente de "Goodwill Global" da empresa.

Efetuadas as avaliacões do Ativo, Passivo e, consequentemente, do Patrimōnio Líquido, pela aplicacão do método adotado, o goodwill global da empresa poderá ser apurado pela diferenca entre os lucros liquidos projetados - um horizonte temporal de projecão muito utilizado é o de 5 anos - descontados pela taxa de remuneracão de em- 
preendimento de igual risco(92), que corresponderia ao custo ao custo de oportunidade investimento.

Algebricamente, o goodwill globai seria representa do como segue:

$$
G=\sum_{t=1}^{n} \frac{L L P_{t}}{(1+j)^{t}}-P L_{v c}
$$

onde: $\quad L L P_{t} \quad \ldots$ Lucro Líquido projetado para o período $t$ futuro:

j ....... Taxa de desconto (custo de oportunidade) correspondente a remuneracão de empreendimento de igual risco;

$\mathrm{PL}_{v c} \ldots \ldots . .$. Patrimonio Lịquido em valores corren tes (excluido o Goodwill).

As revisões anuais do valor do goodwill global sim plificam, sem prejuizo da relevāncia, a sua apuração, dis pensando a utilizacão de formulaçoes mais complexas - uma grande vantagem - que redundariam em um maior grau de risco nos resultados obtidos. 0 mëtodo de valores correntes adota do terá ainda como vantagem o fato de que, dos dados utilizados para apuração do goodwill global, apenas os lucros projetados não estarão presentes nas Demonstracões Contábeis - esses lucros projetados, os seus fundamentos, as tēc-

(92) A definição da taxa ideal, como já foi visto, é de dificil consecuçào, portanto, na prätica, pode-se utilizar a taxa média de retorno sobre o Patrimonio líquido de empresas similares. 
nicas usadas para as projecões e as probabilidades estatîsticas associadas à concretizacão dessas previsões devem intearar as notas explicativas às Demonstra ções Contabeis.

4.3.2. REAVALIAÇ̃̃ES ANUAIS DO GOODWILL GLOBAL

Em 3.2.4.2. foi exposto o posicionamento daqueles que defendem a manutenção do goodwill - no caso o adquirido - como ativo, sem amortização ou qualquer outra alteracão,e, em 3.2.4.4., o posicionamento daqueles que julgam necessä ria a revisão constante do valor desse ativo.

A contabilização em separado de Patentes, fórmulas, Processos não adquiridos $(93)$, fatores de vidas ūteis reconhecidamente limitadas incluidos no goodwill convencional, juntamente com o empenho da administracão no sentido da manutenção ou até aumento da lucratividade da empresa a longo prazo, tornam razoável a adoção da hipōtese de que não há razões para dissociar a durabilidade do goodwill global, do prazo de vida da empresa - as variacões no valor desse goodwill, no decorrer do tempo, resultarão das variacões nas expectativas de lucros e na estrutura patrimonial da empresa, variacões essas que serão apuradas e evidenciadas nas

(93) No caso do goodwill adquirido, os valores desses ativos podem ser avaliados por ocasião da prōpria transacão - ou após, mediante laudos de avaliacão de peritos - e ja contabilizados separadamente pela empresa adqui rente. 
Demonstrações Contābeis.

As reavaliacões $(94)$ anuais terão por bens as novas projecões de lucros, mantendo sempre o horizonte temporal de projecão definido, e o Patrimōnio Liquido em Valores Correntes (excluido o Goodwill) do Balanco Patrimonial do exercício da reavaliação.

4.3.3. CONTABILIZACÃO DO GOODWILL GLOBAL

A caracterizacão do goodwill adquirido como um at vo intangivel especial, pois não dissociāvel da empresa como um todo, é aceita pela quase totalidade dos estudiosos da matéria, assim, da mesma forma, o goodwill global da empresa terá igual enquadramento. Entretanto, não havendo qual quer desembolso ou compromisso de desembolso futuro em rela cão ao valor do goodwill global apurado, o seu lançamento no Ativo deverá ter como contrapartida uma conta do Património Lĩquido, Reserva Especial de Goodwill, cuja finalidade serā a de evidenciar, a cada ano, o reflexo no patrimōnio î́quido da contabilizacão desse goodwill, não podendo ser utilizada para aumento do capital ou para compensacão de prejuízos. Não havendo goodwill adquirido, os saldos das contas Goodwill Global e Reserva Especial de Goodwill serão sempre iguais, embora variando os seus totais pelos ajustamentos decorrentes das reavaliacões anuais.

(94) Lembrar que o termo reavaliações está sendo utilizado "lacto sensu" podendo resultar em ajustamentos para cí ma ou para baixo. 
$\mathrm{Na}$ aquisicão de autra empresa com goodwill, considerando que o preço pago é uma resultante da interacão adquirente/vendedora, trēs são as hipōteses possíveis:

1) preço do goodwill igual ao valor do goodwill apurado-uma ocorrēncia bastante improvāvel, a contabilizacão desse goodwill difere apenas em relação a contrapartida, que serā no prōprio Ativo (diminuicão de Caixa, Bancos ou ou tro ativo cedido na transacão) ou no Passivo, se o desem bolso não for imediato;

2) preço do goodwill menor que o valor do goodwill apuradonesse caso, se as estimativas forem confiāveis, a conta bilização deverá ser efetuada pelo valor do goodwill apu rado, sendo que a diferenca constituir-se-ia em ganho que, tanto poderia ser lancada diretamente contra o re sultado do exercīcio (îtem extraordinário), como lançada a tîtulo de acrëscimo ã Reserva Especial de Goodwill, um procedimento mais cauteloso e mais coerente com a filoso fia de contabilização adotada (95).

3) preço do goodwill maior que o valor do goodwill apuradoutilizando raciocínio análogo, a contabilização terá por

(95) Os resultados relacionados com o potencial de lucros ad quirido e, portanto, com o goodwill, refletir-se-ão aú tomaticamente no desempanho futuro da empresa, podendo, assim,implicar em duplicidade o laņ̣amento daquela diferença diretamente contra o resultado do exercicio.por outro lado, pela forma de contabilização adotada, émais lógico o seu lansamento contra a Reserva Especial de
Goodwill. 
base o valor do goodwill apurado e a diferenca será lancada contra o resultado do exercício (îtem extraordinário) ou, mais coerentemente, como diminuicão da Reserva Especial de Goodwill. Essa è a ūnica situação em que, não havendo qualquer relação do adicional pago com o potencial de lucro estimados, seria justificável a baixa imediata dessa diferenca, como o defendem entre outros Catlett e 01 son.

A ocorrência de saldos diferentes para as contas Goodwill Global e Reserva Especial de Goodwill serão indica tivos da existéncia de goodwill adquirido de terceiros.

Os ajustes decorrentes das reavaliacões anuais efe tuadas serão lançadas como acrēscimos ou diminuicões, con forme o caso, das jä citadas contas Goodwill Global e Reser va Especial de Goodwill, devendo os fundamentos desses ajus tes serem evidenciados em notas explicativas, tendo em vista as suas adequacões aos modelos de decisão dos usuários.

\subsubsection{COMENTARIOS FINAIS}

A função da Contabilidade $\bar{e}$ a de fornecer informacões relevantes para os usuärios e os externos não podem ser discriminados em decorrēncia da necessidade de obediencia dos principios e convencões contābeis geralmente acei tos. Investidores e investidores em potencial tēm o direito de amparar suas decisões em informacões fornecidas pela empresa, da mesma forma que a Administracão tem ā sua dispos cão a Contabilidade Gerencial, que näo se defronta com as 
restricões impostas pelos princīpios e convencões contābeis a livre fluencia de informaçoes relevantes.

A Contabilidade não pode permanecer estātica ante

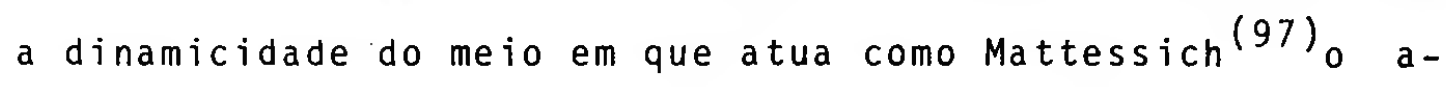
centuou:

"Since we live in a world subject to continuous change there is no reason why accountancy should be spared from the evolutionary and revolutionary forces of time. Indeed, recent technological, mathematical, and scientific developments are at work to exercise an impact on the practice and theory of accounting which has hardly begun to make itself felt but which cannot be ignored, neither by the practicing nor the academic accountant. The adjustment process which these forces bring about entail a rethinking that starts at the very basis of our discipline".

Essa adequação, obrigatoriamente terā que passar por uma reformulacão dos Principios e Convencões Contābeis, os quais foram concebidos num contexto totalmente diferente do atual, tendo-se tornado alguns deles verdadeiros obstácu los ao desenvolvimento da Contabilidade.

(97) Op. cit. p. 3 . 


\section{CONCLUSÖES}




\section{CONCLUSÕES}

Informaçoes sobre o potencial de lucro futuro de uma entidade são de importância fundamental, especialmente para os investidores e investidores em potencial, e o seu "disclosure" se faz necessārio, mesmo em demonstracões paralelas, jā que os Princīpios e Convencões Contābeis Geral mente Aceitos que regem os procedimentos da Contabilidade Financeira não permitem mudanças nos conteudos forma is das Demonstracões Contābeis a publicar.

o goodwill global da empresa, incluindo o adquir $\underline{i}$ do e o não adquirido, torna-se uma informação relevante pa ra o usuārio, não só pelo estabelecimento da comparabilida de entre as Demonstrações Contābeis das empresas, mas também pela evidenciação da contribuicão dos "ativos ocultos" nos desempenhos dessas entidades - a discussão em torno do melhor tratamento contābil do goodwill adquirido leva sempre à necessidade do reconhecimento do goodwill não adquirido.

A Contabilidade precisa registrar todos os recursos que contribuem para o desempenho de uma entidade, não se restringindo aqueles de fācil mensuracão, pois, assim não procedendo, muitos fatores importantes acabam ficando fora dos registros contábeis, provocando distorcões nas 
suas anāilises. A mensuração e contabilizacão de recursos humanos tem merecido estudos e teses, inclusive no Brasil, ficando demonstrada a necessidade de uma definicão em rela cão a forma de "disclosure" daqueles que se constituem,pos sivelmente, no fator de lucro ma is importante de uma empre sa.

Por outro lado, faz-se necessārio tambēm repensar sobre os procedimentos contábeis relativos a gastos com $P$ \& $P$, atualmente considerados como despesas no exercício em que são incorridos, pois acarretam inúmeras distorcões, como foi visto no capitulo III.

A identificação e mensuração do valor econōmico in dividual de todos os ativos, um objetivo ainda distante, não levarā, como o afirmam alguns autores, ao desaparecimento do goodwill - ao contrārio, ele será reduzido a sua expres são mais significativa: o goodwill sinergistico da empresa. $\mathrm{Na}$ impossibilidade de apuracão do valor econōmico indivi dual dos ativos, a alternativa é a utilizacão de métodos de avaliação de ativos que possibilitem mensuracões aproxi madas desse valor econômico.

Os critérios para selecão de mētodos alternativos não podem basear-se nos conceitos tradicionais de objetivi dade e Comparabilidade, mas em conceitos mais significativos e adequados à uma nova realidade. Além disso, não havendo possibilidade de priorizar, ao mesmo tempo a objetividade e a Relevāncia, esta ültima deve merecer a primazia - notas explicativas podem evidenciar os riscos inerentes 
aos dados apresentados.

$\mathrm{Na}$ busca de aproximacões aos valores económicos dos ativos, nenhum método isoladamente é totalmente satisfatōrio, tornando-se necessāria a utilizacão de um mētodo misto, o Método de Valores Correntes, o qual soma as vanta gens do Custo de Reposicão e do Valor de Realizacão, toman do por base a relação empresa-mercado para a definicão da forma de valoracão.

Entretanto, a solucão definitiva para a identificacão e avaliacão dos valores económicos dos ativos implicarā, necessariamente, como o afirmou Mattessich (texto transcrito), na adequação da teoria contābil à realidade cambiante do ambiente em que atua, o que requererá a partí cipação de estudiosos, profissionais da Contabilidade e usuá rios das informacões contäbeis. 
BIBLIOGRAFIA 


\section{BIBLIOGRAFIA}

LIVROS

ALLA, Jean - "L'evaluation de L'entreprise - de la theorie a la pratique" - Edition Cujas - Paris, 1978.

BEAMS, Floyd A. - "Advanced Accounting" - Prentice-Hall, Inc. - Englewood Cliffs, N.J, 1979.

BERNSTEIN, Leopold A. - "Financial Statement Analysis -

Theory, Application and Interpretation" - Revised Edition

- Richard D. Irwin, Inc. - Homewood, Illinois, 1978.

BROZEN, Yale - "Concentration, Mergers, and Public Policy"Macmillan Publishing Co, Inc, NY, 1982.

BURKE, Jr. Frank M. - "Valuation and Valuation Planning for Closely Held Businesses" - Prentice-Hall, Inc. -

Englewood Cliffs, NJ, 1981.

CAMERON, James B; WOELFEL, Charles J.; e PATTILLO, James W. - "Advanced Accounting: Theory and Practice" - Houghton Mifflin Co, Boston, 1979.

CATLETT, George R. e OLSON, Norman 0. - "Accounting for Goodwil1"- Accounting Research Study no 10 - AICPA, NY, 1968.

DAVIDSON, Sidney hWEIL, Roman - "Handbook of Modern Accounting" - 2 Edition - McGraw-Hill Book Co. - NY, 1977.

DEAN, Joel - "Economia das Empresas" - Editora Fundo de Cu] tura, RJ, 1962.

EDWARDS, Edgar 0. e BELL, Philip W. - "The Theory and Measurement of Business Income" - University of California Press - Berkeley, Los Angeles, 1973.

FISCHER, Paul M.; TAYLOR, William James; e LEER, J. Arthur - "Advanced Accounting" - South-Westhern Publishing Co.Cincinati, Ohio, 1978.

GORDON, Myron. e SHILLINGLAW, Gordon - "Accounting A Management Approach" - Richard D. Irwin, Inc. - Homewood, Illinois, 1969. 
HENDRIKSEN, Eldon S. - "Accounting Theory" - Richard D. Irwin, Inc., Homewood, I1linois, 1970.

HENDRIKSEN, Eldon S. e BUDGE, Bruce P. - "Contemporary Accounting Theory" - Dickenson Publishing Co., Inc. Encino, California, 1974.

IJIRI, Yuji - "Theory of Accounting Measurement" - American Accounting Association Studies in Accounting Research Sarasota, Florida, 1975.

IUDICIBUS, Sērgio de; RAMOS, Alkindar de Toledo; KANITZ, Stephen C.; MARTINS, El iseu; WEBER Fo, Eduardo; WEBER Jr., Eduardo; CASTILHO, Edison e BENATTI, Luis - "Contabilidade Introdutōria" - Ed. Atlas, 7ạ Edição - 1986.

IUDICIBUS, Sērgio de; MARTINS, El iseu e GELBCKE, Ernesto "Manual de Contabilidade das Sociedades por Acões" - 2 a Edição - Editora Atlas SA, SP, 1984.

IUDICIBUS, Sērgio de -"Teoria da Contabilidade" - Editora Atlas SA, SP, 1980.

JAEDICKE, Robert K; IJIRI, Yuji; e NIELSEN, Oswald "Research in Accounting Measurement" - American Accounting Association Collected Papers, 1966.

JAENSCH, Gunther - "Valoraciōn de la Empresa" - Editorial Gustavo Gili SA - Barcelona, 1969.

JOHNSON, Gleen L, e GENTRY Jr., James A. - "Finney and Miller's Principles of Accounting - Intermediate" $-7^{\text {th }}$ edition - Prentice-Hall Inc. - Englewood Cliffs, NJ,1974.

LARGAY II I, James A. e LIVINGSTONE, Johan Leslie - "Accounting for Changing Prices - Replacement Cost and General Price Level Adjustments" - John Wiley \& Sons, Inc. - NJ,1976.

MATTESSICH, Richard - "Accounting and Analytical Methods Measurement and Projection of Income and Wealth in the Micro-and Macro Economy" - Richard D. Irwin, Inc. Homewood, Illinois, 1964.

MCCARTHY, George D. e HEALLY, Robert E.-"Valuing a Company - Practices and Procedures" - John Wiley \& Sons-NY,1971.

MEIGS, Walter B.; MOSICHI, A. N.; e LARSEN, E. Joham "Modern Advanced Accounting" - MCGraw-Hill Book Co.,NY, 1979.

MOST, Kenneth S. - "Accounting Theory" $-2^{\text {nd }}$ edition - Grid Publishing Inc. - Columbus, Ohio, 1982.

NISWONGER, C. Rollin e FESS, Philip E. - "Accounting Principles" - 7 th edition - South-western Publishing Co. Cincinati, California, 1973. 
PYLE, William W. e LARSON, Kermit D. - "Fundamental Accounting Principles" - Richard D. Irwin. Inc.-Homewood, Illinois, 1978.

SIMONS, Harry - "Intermediate Accounting" $-5^{\text {th }}$ edition South-western Publishing Co. - Cincinati, Ohio,1974.

SOLOMON, Lanny M.; VARGO, Richard J.; e SCHROEDER, Richard G. - "Accounting Principles" - Harper \& Row Publishers - NY, 1983.

SPILEP Jr. Earl A.- "Financial Accounting: Basic. Concepts"$3^{\text {rd }}$ edition - Richard D. Irwin, Inc. - Homewood, Illinois, 1977 .

WELSCH, Glenn A.; ZLATKOVICH, Charles T.; e HARRISON Jr. Walter T. - "Intermediate Accounting" - 5 th edition Richard D. Irwin, Inc. - Homewood, Illinois, 1979.

TESES, MONOGRAFIAS E DISSERTAÇÕES

FIORINI, Celso Vicente - "Contabilidade de Recursos Huma nos" - Dissertação de Mestrado apresentada ă FEA-USP em 1982 .

IUDICIBUS, Sergio de - "Contribuicão à Teoria dos Ajusta mentos Contäbeis" - Tese de Doutoramento apresentada à FEA-USP em 1966.

IUDICIBUS, Sērgio de - "Aspectos da Avaliação de Estoque a Precos Correntes" - Boletim no 53 - FEA-USP, 1968.

KWASNICKA, Eunice Lacava - "A Contabilizacão de Recursos Hu manos como Instrumento Gerencial - Um Estudo Exploratorio" - Tese de Doutoramento apresentada na FEA-USP, em 1981 .

LEONE, Nilda Maria de C.P. Guerra - "Contabilização dos Re cursos Humanos - Um modelo de Informacão Gerencial "-Dis sertaça de Mestrado apresentada na Universidade Fede ral da Paraiba, em 1983.

MARTINS, Eliseu - "Contribuição A Avaliação do Ativo Intan givel" - Tese de Doutoramento apresentada a FEA-USP e $\bar{m}$ 1972 .

MONTEIRO, Deny da Rocha - "A Contabilidade de Recursos Humanos - Uma exposicão das suas técnicas e uma visão crí tica das suas perspectivas" - Dissertacão de mestrado apresentada na Universidade Federal do R.Janeiro em 1980. 
REVISTAS E PERIODICOS

"ACCOUNTING REVIEW" - Quarterly Journal of the American Accounting Association:

LITTLETON, A.C. - "What is Profit" - vol. 3. 1928 p. 278/ 288.

CANNING, J. B. - "Accounting Theory - Some Divergencies from Economic Theory" - vol. 4, 1929 - p. 1/8.

LITTLETON, A.C. - "Contrasting Theories of Profit" - vol. 11,1936 - p. $10 / 18$.

PATON, W. A. - "Valuation of The Business Enterprise"-vol. 11,1936 p. $26 / 35$.

PREINREICH, Gabriel A.D. - "The Law of Goodwill" - vol. 11, 1936 - P. $317 / 329$.

LITTLETON, A.C. - "The Concepts of Income Underlying Accounting" - vol. 12, 1937 - p. 13/22.

WALKER, George T. - "Nonpurchased Goodwill" - vol. 13,1938 - p. $253 / 259$.

- "Goodwill on Financial Statements"-vol. 13, 1938, p. T74/182.

LUND, Revel I. - "Realizable Value as a Measurement of Gross Income" vol. 16,1941-p. 373/385.

AVERY, Harold G. - "Accounting for Intangible Assets"- vol. 17,1942, p. $354 / 363$.

VANCE, Lawrence L. - "Earning-power valuation of inventory" - vol. 17,1942 - p. $376 / 384$.

BOWERS, Ressel1 - "Economic and Accounting Concepts" - vol. 20,1945 - p. $420 / 431$.

HYLTON, Delmer P. - "Should Financial Statements Show monetary or economic income?" - vol. 26, 1951-p.503/506.

EMERY, Kenneth G. - "Should Goodwill be written off?"-vol. 26,1951 - p. $560 / 567$.

SMITH, Caleb A. - "How can Accounting be Integrated with Economics?". vol. 27, 1952 - p. 100/103.

RAUN, Donald L. - "Income: a Measurement of Currently added Purchasing Power Through Operations" - vol.27,1952 - p. $352 / 358$. 
SCOVILL,H.T. - "An Effort to Define Business Income" - vol. 27,1952 - p. $458 / 466$.

NELSON, Robert H. - "The momentum theory of goodwill"- vol. 28,1953 - p. 491/499.

LEWIS, Ronello B. - "The role of Accounting in Decision Making" - vol. 35, 1960 - p. 37/44.

MOONITZ, Maurice - "Recent Developments in Accounting Theory" - vol. 35, 1960 - p. 206/217.

McCORMICK, Edward T. - "Reporting to Stockholders" - vol. 35,1960 - p. $223 / 227$.

ODMARK, V.E. - "Current Challenges to Accounting Principles"vol. $35,1960-$ p. $272 / 277$.

SOLOMONS, David - "Economic and Accounting Concepts of Income" - vol. 36, 1961 - p. 374/383.

DAVIDSON, H. Justin e TRUEBLOOD, Robert M. - "Accounting for Decision Making" - vol. 36,1961 - p. 577/582.

WALES, Stephen H. - "Intangibles expenses and amortizing intangibles assets" - vol. 37, 1962 - p. 96/98.

SCHATTKE, Rudy - "Expected income - a Reporting Chalienge" v01. 37,1962 - p. $670 / 676$.

JAENICKE, Henry R. - "Managent's Choice to Purchase or Pooling" - vol. 37, 1962 - p. 758/765.

MAURIELLO, Joseph A. - "Realization as the Bas is for Asset Classification and Measurement" - vol. 38,1963-p.26/28.

HENDRIKSEN, Eldon S. - "Purchasing Power and Replacement Cost Concepts are they related?" - vol. 38, 1963 - p. $483 / 491$.

BIERMAN Jr., Harold - "Measurement and Accounting" - vol. 38,1963 - p. $501 / 507$.

PHILIPS, G. Edward - "The Revolution in Accounting Theory" - vol. 38, 1963 - p. $696 / 708$.

ARNETT, Harold E. - "Recognition as a Function of Measurement in the Realization Concept" - vol. 38, 1963 - p. $733 / 741$.

BRILOFF, Abraham J. - "Needed: A Revolution in the Determination and Application of Accounting Principles" - vol. 39, 1964 - p. 12/15.

SPACEK, Leonard - "A Suggested Solution to the Principles Dilemma" vol. 39, 1964-p. 275/284. 
BURKE, Edward J. - Objectivity and Accounting" - vol. 39, 1964 - p. $837 / 849$.

WYATT, Arthur R. - "Accounting for Business Combination : What Next?" vo1. 40, 1965-p. 527/535.

IJIRI, Yuji e JAEDICKE, Robert K. - "Reliability and Objectivity of Accounting Measurements" - vo1.41, 1966 - p. $474 / 483$.

MOBLEY, Sybil C. - "Revenue Experience as a Guide to Asset Valuation" vol. 42,1967-p. 114/123.

BRUMMET, R. Lee; FLAMHOLTZ, Eric G.; e PYLE, William C. "Human Resource Measurement - A Challenge for Accountants" vol.43, 1968.p. $217 / 224$.

JOHNSON, Orace - "Some Reservations on the Significance of Prospective Income Data" - vol. 43, 1967 - p. 546/548.

FREMGEN, James M. - The Going Concern Assumption:a Critical Appraisal" - vol. 43, 1968 - p. 649/656.

BRIEF, Richard P. - "An Econometric Analysis of Goodwill: Sone Findings in a Search for Valuation Rules" - vol. 44, 1968 - p. $20 / 26$.

TRITSCHLER, Charles A. - "Statistical Criteria for Asset Valuation by Specific Price Index" - vol.44, 1969 - p. $99 / 123$.

GYNTHER, Reg. S. - "Some Conceptualizing on Goodwill"-vol. 44,1969 - p. $247 / 255$.

GOLDSCHIMIDT, Y. e SMIDT, S. - "Valuing the Firm's Durable Assets for managerial Information" - vol. 44, 1969 - p. $317 / 329$.

SNAVELY, Howard J. - "Current Cost for Long-Lived Assets:a Critical View" - vol. 44, 1969 - p. 344/353.

FERTAKIS, John P. - "On Communication, Understanding and Relevance in Accounting Reporting" - vol.44,1969 - p. $680 / 691$.

SIMMONS, John K. e GONEDES, Nicholas J. - "An Investigation of the Effect of Differing Accounting Frameworks on Prediction of Net Income" - vol.44,1969-p.757/776.

WOJDAK, Joseph F. - "Levels of Objectivity in the Accounting Process" vol. 45, 1970-p. 88/97.

SHWAYDER, Keith - "A Proposed Modification to Residual Income" - vol. 45, 1970 - p. 299/307. 
PENMAN, Stephen H. - "What Net Asset Value? - An Extension of a Familiar Debate" - vol. 45, 1970 - p. 333/346.

REVSINE, Lawrence - "On The Correspondence Between Replacement Cost Income and Economic Income" - vol. 45, 1970 - p. $513 / 523$.

JOHNSON, Orace - "Toward Events Theory of Accounting".vol. 45,1970 - p. $641 / 653$.

VICKREY, Don W. - "Is Accounting a Measurement Discipline?" - vol. 45, 1970 - p. 731/742.

LEV, Baruch e SCHWARTZ, Aba - "On the Use of Economic Concept of Human Capital in Financial Statements" - vol. 46,1971 - p. 103/112.

FLAMHOLTZ, Eric - "A Model for Human Resource Valuation: A Stochastic Process with Service Rewards" - vol. 46,1971 - p. $253 / 267$.

BEDFORD, Norton M. e MCKEOWN, James C. - "Comparative Analys is of Net Realizable Value and Replacement Costing" - vol. 47, 1972 - p. $333 / 338$.

CHAMBERS, Raymond $\mathrm{J}$. - "Measurement in Current Accounting Practices: A critique" - vol. 47. 1972 - p. 488/509.

FLAMHOLTZ, Eric - "Toward a Theory of Human Resource Value in Formal Organizations" - vol. 47, 1972 - p.666/678.

PETERSEN, Russel1 J. e KELLER, Thomas F. - "Asset Valuation, Income Determination and Changing Prices" - vol. 47, 1972 - p. $801 / 805$.

MILLER, Malcolm C. - "Goodwill - An Aggregation Issue"-vol. 48,1973 - p. $280 / 291$.

NICHOLS, Donald R. - "Comparative Analysis of Net Realizable Value and Replacement Costing - A Comment" - vol. 48, 1973 - p. $383 / 385$.

MCKEOWN, James C. - "A Brief Exploration of The Goal Congruence of Net Realizable Value" - vol. 48, 1973 - p. $386 / 388$.

MCDONALD, Charles L." "An Empirical Examination of The Reliability of Published Predictions of Future Earnings" - vol. 48,1973 - p. 502/510.

CLARK, John J. e ELGERS, Pieter - "Forecasted Income Statements: An Investor Perspective" - vol.48,1973 - p. $668 / 678$.

DERMER, Jerry e SIEGEL, Jacob P. - "The Role of Behavioral Measures in Accounting for Human Resources"-vol.49,1974 p. $88 / 97$. 
JAGGI, Bikki e LAU, Hon-Shiang - "Toward a Model for Human Resource Valuation" - vol.49, 1974 - p. 321/329.

EDWARDS, Edgar 0. - "The State of Current Value Accounting" - vol. 50, 1975 - p. 235/245.

PARKER, James E. - "Testing Comparability and Objectivity of Exit Value Accounting" - vol. 50, 1975 - p. 512/524.

ABDEL-KHALIK, A. Rashad - "Advertising Effectiveness and Accounting Policy" - vol. 50, 1975 - p. 657/670.

HENDRICKS, James A. - "The Impact of Human Resource Accounting Information on Stock Investment Decisions: An Empirical Study" - vol. 51, 1976 - p. 292/305.

OGAN, Pekin - "A Human Resource Value Model for Professional Service Organizations" - vol. 51, 1976 - p. 306/320.

CASPARI, Johan A. - "Wherefore Accounting Data - Explanation, Prediction and Decisions" - vol. 51, 1976 - p.739/746.

Cook, John S. e Holzmann, Oscar J. - "Current Cost and Present value in Income Theory" - vol. 51, 1976-p.778/787.

JOHNSON, Orace - "Contra-equity Accounting for $R$ \& D".vol. 51, i 976 - p. 808/823:

ASHTON, Robert H. - "Objectivity of Accounting Measures: A Multirule-Multimeasurer Approach" - vol.52,1977 p.567/ 575 .

TOMASSINI, Lawrence A. - "Assessing the Impact of Human Resource Accounting: An Experimental Study of managerial Decision Preferences" - vol.52, 1977 - p. $904 / 914$.

FRIEDMAN, Laurence A. - "An Exit-price Income Statement" V01.53,1978-p. $31 / 47$.

BEAVER, William H. e DEMSKI, Joel S. - "The Nature of Income measurements" - vol. 54, 1979 - p. 38/46.

SAMUELSON, Richard A. - "Should Replancement Cost Changes be Included in Incomo?" - vol. 55, 1980a p. $254 / 268$.

RICHARDS, Don-Rice - "Estimating Current Value: Some Techniques, Problems and Experiences" - vol. 55,1980 - $528 / 529$.

DITTMAN, David A.; JURIS, Hervey A.; REVSINE, Lawrence "Unrecorded Human Assets: A Survey of Accounting Firms" Training Programs" - vol.56,1981-p. 640/648.

BOATSMAN, James R. e BASKIN, Elba F. - "Asset Valuation with Incomplete Markets" vol. 56, 1981 - p. 38/53. 
IJIRI, Yuji e NOEL, James - "A Reliability Comparison of The Measurements of Wealth, Income, and Force" - vol. 59,1984 - p. $52 / 63$.

KAPLAN, Robert S. - "The Evolution of Managerial Accounting" - vol. 59, 1984 - p. 390/418.

"JOURNAL OF ACCOUNTING RESEARCH" - Institute of Professional Accounting Graduate School of Business - University of Chicago:

CARSBERG, Bryan V. - "The Contribution of P.D. Leake to the Theory of Goodwill Valuations" - vol. 4, no 1, 1966 - p. $1 / 15$.

BAXTER, W. T. - "Accounting Values: Sale Price X Replacement Cost" - vol. 5, no 2, 1967 - p. 208/214.

BEDFORD, Norton M. - "The Foundations of Accounting Measurement" - vol. 6, no 2, 1968 - p. $270 / 282$.

BRIEF, Richard P. e OWEN, Joel - "The Estimation Problem in Financial Accounting" - vol. 8, nọ 2, 1970 - p. 167/ 177 .

JARRET, Jeffrey E. - "The Principles of Matching and Reali zation as Estimation Problems" - vol.9, no 2, $1971=$ p. $378 / 382$.

MARTIN, Alvin - "An Empirical Test of The Relevance of Accounting Information for Investment Decisions" - vol. 9, Supplement - Empirical Research Studies in Accounting: Selected Studies - 1971 - p. 1/49.

MARSHALL, Ronald M. - "Determining an 0ptimal Accounting Information System for an Unidentified User" - vol. 10, no 2, 1972 - p. 286/307.

ELIAS, Nabil - "The Effects on Human Asset Statements on the Investment Decision: An Experiment" - vol. 10 Supplement - Empirical Research Studies in Accounting: Selected Studies - 1972 - p. $215 / 240$.

FRIEDMAN, Abraham e LEV, Baruch - "A Surrogate Measure for The Firm's Investment in Human Resources" - vol. 12 , n? 2,1974 - p. 235/250.

MORTON, James R. - "Qualitative Objectives of Financial Accounting: a Comment on Relevance and Understandability" - vol. 12, no 2, 1974 - p. 288/298.

FALK, Haim e MILLER, Joseph C. - "Amortization of Advertising Expenditures" - vol. 15, no 1, 1977 - p. 12/22. 
ARNOLD, Donald F. e HOEFNER, Ronald J. - "Measuring and Evaluating Replacement Costs: An Application" - vol. 15, n? 2, 1977 - p. 245/252.

PICCONI, Mario J. - "A Reconsideration of The Recognition of Advertising Assets on Financial Statements" - vol. 15, no 2, 1977 - p. $317 / 326$.

LAU, Amy Hing-Ling e LAU, Hon-Shiang - "Some Proposed Approaches for Writing of Capitalized Human Resource Assets" - vol. 16, nọ 1, 1978 - p. 80/102.

BROWNELL, Peter - "The Role of Accounting Data in Performance Evaluation, Budgetary Participation, and Organiza tional Effectiveness" - vol. 20, no 1, 1982 - p. 12/27.

MORSE, Dale e RICHARDSON, Gordon - "Opportunity cost and Behavior", vol. 21, nọ 1, 1983 - p. 106/127.

"ADMINISTRACION DE EMPRESAS" - Ediciones Contabilidad Moderna SAIC - Buenos Aires:

BERTOLETTI, Mario E. - "Sinergia: un Concepto de Alta Estrategia" - vol. I-A, p. 315/319.

KAWAOKA, Teruo e TAKEZAKI, Touru - "Información Contable y Toma de Decisiones" - vol. II-A, p. 23/37.

BIONDI, Mario; FORTINI, Hernando L.; SANTISO, Horacio Lōpez; LUPPI, Hugo; OTERO, Alfonso; OUTEIRAL, Luis E.; SLOSSE, Carlos A.; URRIZA, Jose - "Ideas para una Refor mulación total de los Principios de Contabilidad Generalmente Aceptados" - vol. VI-A, p. 345/366.

NEWTON, Enrique Fowler e FORTINI, Hernando L. - "Revisiōn de los Principios y Normas de Contabilidad Generalmente Aceptados" - vol. VI-A, p. $367 / 383$.

LAWLER III, Edwald E.; SUNDEM, Gary; RHODE, John G. - "Con tabilización del Valor de los Recursos Humanos" - vol. $V I-A$, p. $465 / 479$.

SUJANOV, Victor - "La Controversia entre Costos Histöricos $y$ Valores Corrientes ante la Inflación - vol. VII-B, p. $837 / 854$.

VIII-A, p. $289 / 298$.

HAND, John H. e LLOYD, William P. - "Un Metodo para Determinar el Valor de una Pequeña Empresa" - vol. XII-B, p. 719 . 
GARIBOTI, Domingo A.; MIGUEL, Cleo Laura; ACUNA, Ricardo Pahlen; e CHAVES, Osvaldo A. - "Ensayo sobre la Fundamentación Logica y Corroboraciōn del Modelo Contable de Valores Corrientes" - vol. XIV-B, p. 1023/1040.

"THE ACCOUNTANTS JOURNAL":

HARRIS, J. E. - "Some Aspects of Accounting in the Common Market" - abril/1963, p. 123/125.

GRAHAM, Pauline M. - "U.E.C. - Uniōn Europēenne des Experts Comptables Economiques et Financiers" - june/1964, p. $253 / 255$. 